


\title{
Ecos do mundo zero: guia de interpretação de futuros, aliens e ciborgues
}

Autor(es): $\quad$ Rodrigues, Elsa Margarida

Publicado por: Imprensa da Universidade de Coimbra

URL

persistente: $\quad$ URI:http://hdl.handle.net/10316.2/11960

DOI: $\quad$ DOI:http://dx.doi.org/10.14195/978-989-26-0578-4

Accessed : $\quad$ 26-Apr-2023 13:06:37

A navegação consulta e descarregamento dos títulos inseridos nas Bibliotecas Digitais UC Digitalis, UC Pombalina e UC Impactum, pressupõem a aceitação plena e sem reservas dos Termos e Condições de Uso destas Bibliotecas Digitais, disponíveis em https://digitalis.uc.pt/pt-pt/termos.

Conforme exposto nos referidos Termos e Condições de Uso, o descarregamento de títulos de acesso restrito requer uma licença válida de autorização devendo o utilizador aceder ao(s) documento(s) a partir de um endereço de IP da instituição detentora da supramencionada licença.

Ao utilizador é apenas permitido o descarregamento para uso pessoal, pelo que o emprego do(s) título(s) descarregado(s) para outro fim, designadamente comercial, carece de autorização do respetivo autor ou editor da obra.

Na medida em que todas as obras da UC Digitalis se encontram protegidas pelo Código do Direito de Autor e Direitos Conexos e demais legislação aplicável, toda a cópia, parcial ou total, deste documento, nos casos em que é legalmente admitida, deverá conter ou fazer-se acompanhar por este aviso.

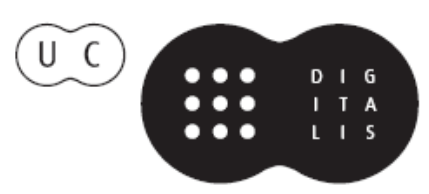



(Página deixada propositadamente em branco) 
焉

$\frac{\mathrm{I}}{\mathrm{U}}$ 


\section{EDIÇÃO}

Imprensa da Universidade de Coimbra

Email: imprensauc@ci.uc.pt

URL: http://www.uc.pt/imprensa_uc

Vendas online: http://www.livrariadaimprensa.com

CONCEÇÃO GRÁFICA

António Barros

\section{INFOGRAFIA DA CAPA}

Carlos Costa

PRÉ-IMPRESSÃO

Mickael Silva

Xavier Gonçalves

EXECUÇÃO GRÁFICA

www.artipol.net

ISBN

978-989-26-0140-3

ISBN Digital

978-989-26-0578-4

DOI

http://dx.doi.org/10.14195/978-989-26-0578-4

DEPÓSITO LEGAL

347522/12 


\section{ECOS

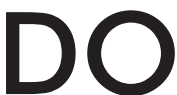 \\ MUNDO \\ ZERO}

GUIA DE INTERPRETAÇÃO

DE FUTUROS, ALIENS E CIBORGUES

ELSA MARGARIDA RODRIGUES

IMPRENSA DA UNIVERSIDADE DE COIMBRA

COIMBRA UNIVERSITY PRESS 
(Página deixada propositadamente em branco) 


\section{SUMÁRIO}

INTRODUÇÃO

\section{FICÇÃO CIENTÍFICA}

MAPEAMENTO CONCEPTUAL

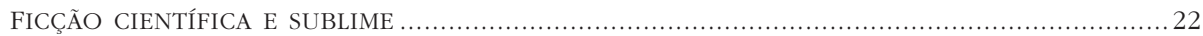

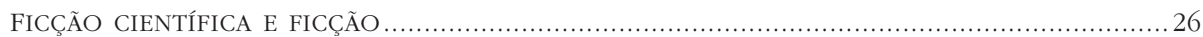

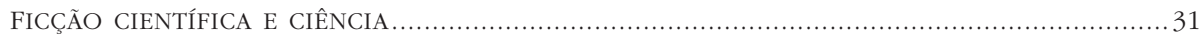

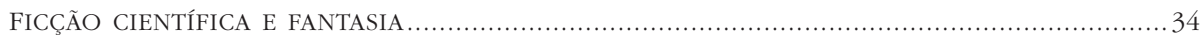

\section{HISTÓRIA DA FICÇÃO CIENTÍFICA}

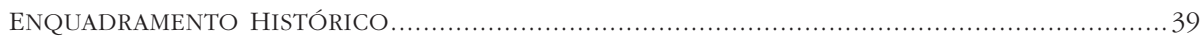

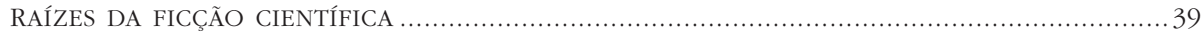

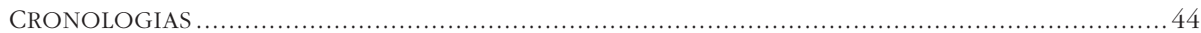

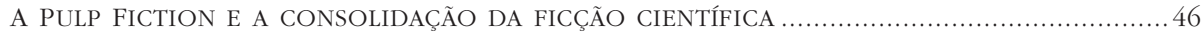

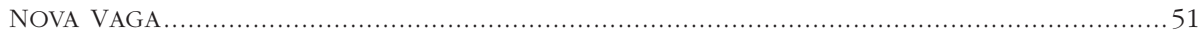

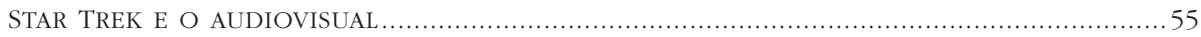

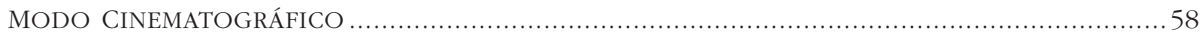




\section{TIPOLOGIAS DA FICÇÃO CIENTÍFICA}

SUB-GÉNEROS E CATEGORIAS 63

ESPAÇO, TEMPO, MÁQUINA E MONSTRO...... 64

ATUANTES E TOPOI .66

ÍCONES 67

Alteridade, TECNOlOGIA, TEMPO E ESPAÇO 68

\section{CINEMA DE FICÇÃO CIENTÍFICA}

CINEMA E FICÇÃO CIENTÍFICA .73

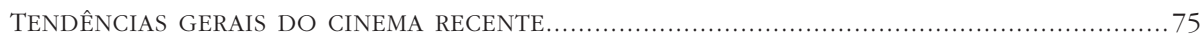

BREVE HISTÓRIA DO CINEMA DE FICÇÃO CIENTÍFICA ……............................................. 80

V ALTERIDADE, TECNOLOGIA, TEMPO E ESPAÇO

NO CINEMA DE FICÇÃO CIENTÍFICA

ALTERIDADE

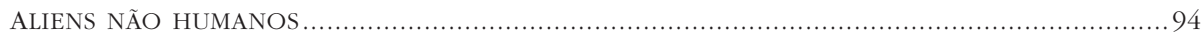

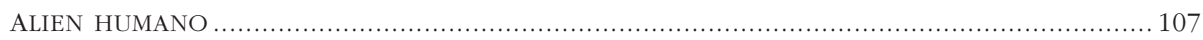

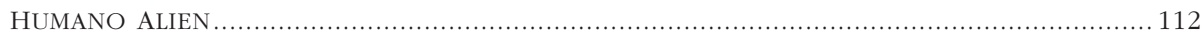

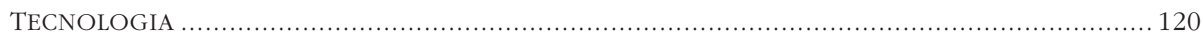

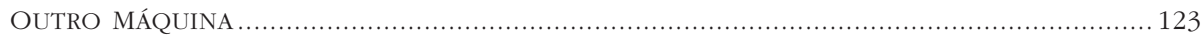

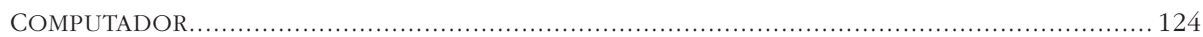

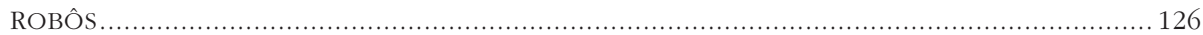

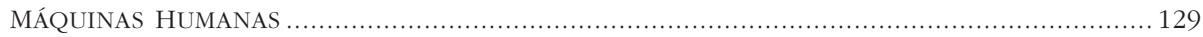

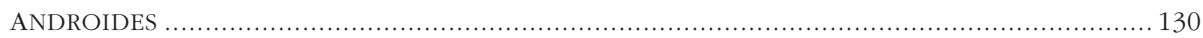

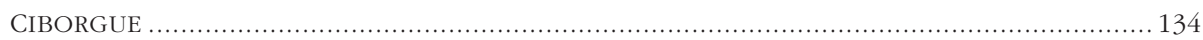

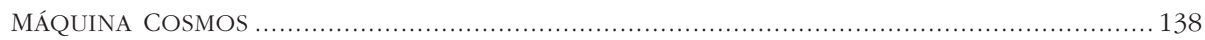

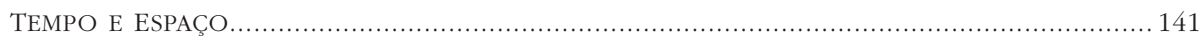




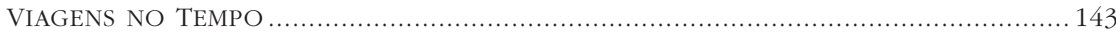



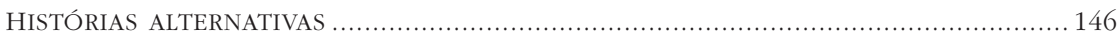

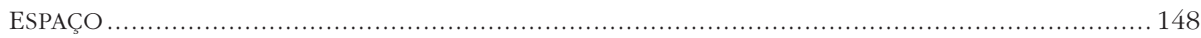

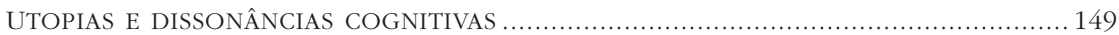

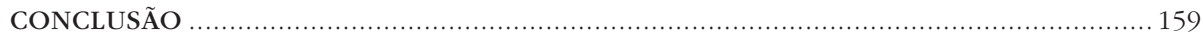

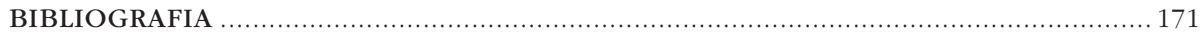

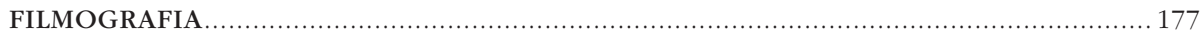


(Página deixada propositadamente em branco) 
O problema dos nossos tempos é que o futuro já não é o que era.

Paul Valéry 
(Página deixada propositadamente em branco) 


\section{NTROD UÇ Ã O}

A geração que chorou com as desventuras do pequeno extraterrestre de E.T. e brincou no recreio com sabres de luz imaginários chegou agora à meia idade. Assistiu, fascinada, às aventuras da tripulação da Enterprise, à luta de Luke Skywalker e dos cavaleiros Jedi contra as forças do Império, à irrupção do alien pelo peito de Kane, à implacabilidade do exterminador enviado do futuro e a outras cenas memoráveis que contribuíram para a formação do seu imaginário.

Foi uma geração que cresceu com imagens de vastidão espacial, viagens intergalácticas, planetas distantes e entidades extraordinárias, que permitiram imaginar o absolutamente alienígena numa altura em que o próprio planeta parecia definitivamente mapeado e conhecido. Foi a geração que se habituou a ver o futuro no écran e a esperar dele dispositivos tecnológicos e avanços científicos excecionais. Foi também a geração que chegou à idade adulta e ao ano 2000 com um vago sentimento de desilusão pela aparente banalidade da vida e do mundo, incapazes de cumprir a espetacularidade prometida durante décadas pelas narrativas do cinema norte-americano.

Mas afinal qual foi o contributo da ficção científica para a planificação e construção de um futuro que rapidamente se tornou presente? Qual o seu papel na validação ou erosão do paradigma científico e tecnológico dominante e na forma de encarar a alteridade? Será a ficção, enquanto narração imaginada do mundo, capaz de oferecer mapas de compreensão do real? Poderá ter tido algum contributo para o mal estar e indeterminação existencial que acompanha a vivência da pós-modernidade? E o cinema, meio de comunicação predominantemente sensorial e afetivo, terá a capacidade 
de produzir efeitos cognitivos e epistemológicos relevantes que possam ter impacto na estruturação da própria realidade?

Estas são algumas das questões que este livro coloca, pocurando demonstrar que, mesmo como espetáculo de massas, a ficção científica cinematográfica não é meramente dirigida à satisfação de necessidades sublimativas mas cumpre funções mais amplas, de crítica epistemológica, social e ecológica. Ela projeta os medos e anseios do mundo real em espaços, tempos e entidades imaginadas, capazes de provocar simultaneamente inquietação e fascínio, temor e encantamento, modos de sentir que estruturam, muitas vezes de forma indelével, a cognição do mundo.

Instituída como forma de entretenimento sedutora e fácil de consumir, a ficção científica conduz o espetador por reflexões sobre o especificamente humano e o efetivamente real, atuando na perceção do mundo e nos sistemas de atribuição de sentido. O que torna o género eficaz na capacidade de perturbar o sentir e pensar do espetador é a gestão entre estranheza e verosimilhança. A ficção científica é a imaginação do desconhecido, do estranho, do novo, feita dentro dos limites do possível e do plausível.

Constitui-se como uma forma alternativa de representar o mundo, situada entre a fantasia e a racionalidade, que opera através da imaginação ficcional ancorada ao possível. A imaginação, enquanto capacidade de projetar e de reconfigurar o existente, é usada enquanto capacidade de criação e de pensamento crítico, epistemologicamente válido, enquanto possibilidade de dilatar o real mantendo o respeito pelas suas evidências e a obediência às suas leis. Enquanto forma de projeção do aqui e agora noutros espaços e tempos, formula hipóteses verosímeis e justificáveis, fundadas na racionalidade científica e tecnológica mas transcendendo-a, podendo mesmo questioná-la ou criticá-la. Deste modo, é na ficção científica que encontramos uma das narrativas que melhor traduz as incertezas epistemológicas, ontológicas e identitárias pós-modernas, oferecendo resoluções imaginadas para os conflitos ou tensões da realidade e pensamento contemporâneos que integram a fluidez do presente e a imaginação do futuro.

A própria realidade parece, ao longo do último século, ter sofrido processos de compressão e dilatação por efeito da ciência e, principalmente, da tecnologia. Pode considerar-se que a ficção científica permite dar ex- 
pressão à necessidade epistemológica de conferir inteligibilidade ao devir de uma realidade que obriga a contínuas reconfigurações do tempo e espaço, e à reconstrução permanente de identidades. Daí que vários autores, como Fredric Jameson, vejam na ficção científica um dos modos de cartografar cognitivamente o presente como passado de futuros possíveis, sublinhando os riscos de um mundo que assume ele próprio uma textura de ficção científica, marcado pelo impacto da tecnologia na vida quotidiana, pela crescente virtualização de dimensões importantes da existência, pela desconfiança em relação à capacidade de modelos políticos e culturais, instituições sociais e até os próprios indivíduos conseguirem responder aos desafios de um mundo cada vez mais marcado pela incerteza.

Fatores como a informatização e globalização do mundo contribuíram para erodir os pilares da formação identitária do sujeito moderno. O próprio Estado-Nação, enquanto comunidade imaginada agregada pelo sentimento coletivo de pertença a uma totalidade contida, encontra-se sujeito às forças simultâneas de homogeneização e diferenciação culturais. Identidades e subjetividades descentram-se, revelando a multiplicidade e hibridez das experiências e condições que as constituem. Por outro lado, a uniformização imposta pela globalização e o emergir das identidades minoritárias aumentam o fascínio pela diferença e, consequentemente, pelas narrativas que a podem traduzir.

Os outros da ficção científica, sejam alienígenas ou máquinas, respondem a este fascínio pela diferença, e os eus, heróis ou anti-heróis, traduzem a complexidade e plasticidade dos sujeitos, refletindo as múltiplas formas de diferenciação e, principalmente, de assimilação entre o eu e o outro, o humano e o não humano, o natural e o tecnológico. A crescente indistinção entre o real e o virtual, tema muito presente na ficção científica recente, potencia o processo de diferenciação identitária, obrigando a repensar a unidimensionalidade do eu, as fronteiras do humano e o modo como a tecnologia permite a sua reconfiguração.

A tecnologia, na medida em que complementa, substitui ou interseta o humano e reorganiza o espaço, o tempo e as relações, institui-se como categoria estrutural na imaginação do eu e do mundo, encontrando-se nas narrativas ficcionais de matriz tecnológica a expressão das esperanças e 
ansiedades relativas ao papel que as máquinas, mais ou menos inteligentes, desempenharão na construção do futuro e na reconfiguração do humano.

Tempo e espaço, na medida em que podem ser dilatados, comprimidos, ultrapassados e reconfigurados, são também categorias centrais para a ficção científica, capaz de construir heterotopias e heterocronias, espaços e tempos outros, melhores ou piores do que o mundo empírico no qual o espetador se situa. Neste aspeto, o género pode considerar-se essencialmente revolucionário: a projeção da alteridade ou de futuros distópicos envolve quase sempre uma forma de crítica ao status quo e aos discursos dominantes, nomeadamente ao político, ao militar, ao médico, ao científico, ao tecnológico ou ao capitalismo enquanto modo de produção, como acontece em quase todos os filmes de ficção científica das últimas três décadas. Mesmo quando o espaço ou o tempo são imaginados de forma positiva e otimista em propostas utópicas, as correções realizadas ao mundo para o tornar melhor implicam uma crítica e sugerem uma nova direção de ação que permite corrigir o presente.

No entanto, embora revolucionária ao nível dos temas e da abordagem que faz, a ficção científica não pode considerar-se um counter-cinema, um cinema crítico alternativo e produzido de forma independente. Ela continua a utilizar os modos de produção e distribuição capitalistas e serve os propósitos da ideologia dominante que explícita ou implicitamente critica. Radicalizando este argumento, pode mesmo afirmar-se que ela transforma o criticismo em espetáculo de massas, num produto cultural de sucesso, fabricado e difundido em moldes industriais. Esta ambivalência torna a ficção científica difícil de classificar em termos ideológicos. Ela acompanha e reforça a erosão das certezas e dos metadiscursos a que se assiste no mundo real, promovendo um criticismo cultural e uma espécie de epistemologia de massas, mas fá-lo usando os mecanismos da ideologia e modo de produção dominante, o que torna questionável o seu potencial reflexivo.

Susan Sontag foi uma das autoras que duvidou da potencialidade crítica do cinema de ficção científica, reduzindo o género à capacidade de imaginar o desastre. No entanto, esta não é uma opinião consensual. Muita da análise crítica acerca da ficção científica sublinha a sua importância, sobretudo na relação entre este género narrativo e a pós-modernidade, entre a 
ficção e a reconfiguração, aparentemente ficcional, do mundo, considerando que o género moldou a mundovisão contemporânea. Ao longo das últimas décadas é da ficção científica que vêm muitos dos referentes mentais e conceptuais com que o mundo ocidental opera e é a partir dela que se realiza o debate sobre temas atuais que poderão ter um impacto profundo no modo como o futuro poderá vir a ser. Jameson $(1995,2005)$ é um dos teóricos contemporâneos que chama a atenção para o papel fundamental que a ficção científica desempenha na configuração dos problemas ideologicamente fundamentais da pós-modernidade por projetar no futuro as contradições ideológicas de cada presente. Conclui que a ficção científica, enquanto colagem de múltiplos géneros e síntese de diversas influências, é a expressão literária do capitalismo tardio.

A imaginação de outros espaços, tempos e formas de existir, ancorada na plausibilidade, oferece uma outra forma de pensar o presente para além da racionalidade científica e das meta narrativas, respondendo às necessidades epistemológicas pós-modernas. Pode mesmo considerar-se que 'pós' é o modo da ficção científica, a imaginação daquilo que vem depois do presente, do apocalipse, da invasão, da infeção, da alienação do humano, concretizados numa variedade de cenários que a transformam numa ferramenta eficaz para dilatar o real, mantendo o respeito pelas suas evidências e a obediência às suas leis. Constitui-se por isso como o género narrativo que melhor traduz as incertezas epistemológicas, ontológicas e identitárias pós-modernas, oferecendo resoluções imaginadas para os conflitos ou tensões da realidade e pensamento contemporâneos que integram a fluidez do presente e a imaginação do futuro.

Para comprovar a premissa de que a ficção científica é o modo discursivo que melhor serve para explorar as questões científicas, tecnológicas, sociais, políticas, culturais e identitárias, explicitando as contradições da realidade presente e mostrando como elas se poderão transformar com a passagem do tempo, mudança de espaço, transformações científicas e tecnológicas ou introdução de elementos alienígenas, este livro procede a uma panorâmica pelo género, centrando-se na sua expressão cinematográfica, procurando compreender as formas como ela reflete e dá resposta às 
profundas alterações mentais, sociais, identitárias e tecnológicas que vão decorrendo no mundo real de que parte.

O primeiro capítulo explora as fronteiras conceptuais da ficção científica e as relações de transgressão ou hibridez com outras formas de compreensão e projeção do mundo, nomeadamente a história, a ciência e a religião, abordando-se também o estatuto da ficção científica no interior das narrativas ficcionais e a sua ligação à racionalidade científica de que deriva como subproduto.

No segundo capítulo traça-se a evolução histórica da ficção científica enquanto género narrativo, sublinhando o modo como o meio de comunicação em que é expressa e as características do contexto histórico de origem determinam temas e formatos de difusão, obrigando a movimentos adaptativos que permitem constituir novos públicos e conduzi-la ao fenómeno cultural de massas que atualmente é.

Enquanto género de fronteira, adaptativo e tematicamente rico, tornou-se necessário analisar os tipos de narrativa que a ficção científica pode conter, apresentando-se algumas das tipologias que têm sido propostas, adaptáveis ao formato literário ou cinematográfico.

Num quarto capítulo é tratada a especificidade da ficção científica enquanto género cinematográfico, destacando a sua capacidade, ao longo da história do cinema, de traduzir as ansiedades do momento histórico em visões que articulam questões epistemológicas, ontológicas, sociais e existenciais.

A análise das narrativas cinematográficas é feita através da aplicação, diacrónica e sincrónica, das categorias definidas como estruturantes para a ficção científica: a alteridade, a tecnologia, o tempo e o espaço, procurando determinar-se a solução proposta por cada grupo de narrativas para as antinomias em jogo em cada uma das categorias.

Para a análise fílmica optou-se por uma metodologia que funde elementos propostos pelas várias teorias do cinema. As teorias clássicas centram-se na análise do filme como obra de arte. Os especialistas em semiótica leem o cinema como uma combinação específica de códigos. As teorias cognitivistas e psicanalíticas procuram a natureza da relação entre o filme e o espetador, centrando-se nas competências exigidas ou nas retribuições alcançadas. O estruturalismo procura a função ideológica da narrativa. 
Premissas de todas estas teorias estão presentes ao longo deste estudo, em que o cinema é tomado simultaneamente como arte, espetáculo, linguagem, narrativa, recurso para cartografias cognitivas, fonte de recompensas afetivas e veículo ideológico.

A metodologia dominante é a pesquisa documental, bibliográfica e fílmica. Procedeu-se depois a uma abordagem do material recorrendo ao criticismo temático, procurando em cada obra um tema geral que garante a coerência e unidade textual e que permite enquadrá-lo dentro do género. Nas situações em que esta delimitação se tornou problemática, aplicou-se a noção, proposta por Roland Barthes, de que a força do sentido depende da repetição de certos elementos, determinando-se a predominância de cada tema ao longo das cenas do filme.

Em termos de conteúdo, recupera-se o modelo estruturalista de pares binários como blocos constitutivos de todas as narrativas, assumindo-se que, à imagem do mito para Lévi-Strauss, o filme funciona como narrativa que permite resolver de forma imaginária as contradições do mundo contemporâneo. O levantamento das antinomias, dos elementos aparentemente contraditórios e inconciliáveis, permite verificar de que modo o cinema de ficção científica traduziu os conflitos epistemológicos do mundo real e que soluções e valores propôs para a sua resolução.

Será importante referir que esta investigação, como qualquer outra, parte de um conjunto de pressupostos que se constituem como topoi discursivos, pontos de partida que refletem uma herança cultural e um posicionamento físico e epistemológico individuais. Utilizando a noção proposta por Donna Haraway (1991), pensar implica mobilizar os recursos e ferramentas que se possui, projetando o sujeito no objeto, criando novos enquadramentos e modos de ver. Só assim será possível uma melhor compreensão da realidade, especialmente da realidade social, por aproximações sucessivas, reveladoras da subjetividade do investigador mas, acima de tudo, da multidimensionalidade e polivalência dos fenómenos e da sua ligação numa teia invisível de inter-relações. Criar estruturas interpretativas, imaginar relações de causalidade plausíveis e epistemologicamente ancoradas, implica um compromisso do investigador com a realidade e com o futuro que dela deriva, tal como acontece com o criador de ficção científica. 
Este livro, à imagem das narrativas que trata, propõe ao leitor uma grelha interpretativa da sua experiência enquanto espetador de ficção científica e enquanto habitante de um presente que se assemelha aos cenários que lhe foram mostrados pela ficção científica. Porque, como defende Donna Haraway $(i d$.$) , a fronteira entre a ficção científica e a realidade é, cada vez$ mais, uma ilusão de ótica. 


\section{FICÇÃO CIENTÍFICA}

\section{Mapeamento conceptual}

A ficção científica é um fenómeno híbrido, de fronteira, onde confluem a história, a ciência e a religiosidade, e onde se combinam a fantasia e a realidade, a racionalidade e a imaginação, o encantamento e a crítica, passados alternativos, presentes possíveis e futuros imaginados.

É no ponto de intersecção de tudo isto, entre religião e ciência, entre realismo e fantasia, entre ciências humanas e físicas, que se encontra uma nova forma de imaginação verosímil, um género que emerge em todo o seu esplendor no século xx, século em que, contraditoriamente, é fornecida a maior quantidade de explicações e a menor quantidade de certezas. Como resume brilhantemente Eduardo Prado Coelho:

"Com Copérnico, o homem deixou de estar no centro do Universo. Com Darwin, o homem deixou de ser o centro do reino animal. Com Marx, o homem deixou de ser o centro da história (que, aliás, não possui um centro). Com Freud, o homem deixou de ser o centro de si mesmo (que também nem sequer existe, é apenas um lugar vazio, uma brecha, uma voragem) e aprendeu que ele próprio é constituído por uma estrutura, a estrutura da linguagem."1

Mas podemos ainda acrescentar a este ruir de certezas do século xx que as guerras mundiais, os desastres ecológicos e as reflexões epistemológicas

\footnotetext{
${ }^{1}$ Coelho, s/d: XXXVIII.
} 
erodem a fé no racionalismo e na possibilidade de uma ciência objetiva, pura e descomprometida, do mesmo modo que o crash da Bolsa de 1929, o Macarthismo e o acentuar das desigualdades abalam o sonho capitalista e democrático americano, e Estaline (e a posterior queda do muro de Berlim) abalam a utopia socialista. A razão, enquanto instância de clarividência, capaz de distinguir o justo do injusto, o verdadeiro do falso, o bem do mal, enquanto fonte de bom senso moral, económico ou político, parece fatalmente ferida, privando a humanidade da sua principal ferramenta mental.

Esta convulsão paradigmática, vivida desde finais do século XIX, dá origem a novas grelhas e novas conceção de tempo, espaço e humanidade. Scholes (1975) aponta Darwin como o principal responsável pelo fim do homem histórico (bistorical man) ao expandir o sentido do tempo e dar à humanidade um papel transitório no lento e longo processo de desenvolvimento das espécies, e considera os contributos de Einstein, Köhler e Lévi-Strauss essenciais para a emergência do homem estrutural (structural man). Carl Malmgren (1991), por seu lado, considera a publicação da obra Princípios de Geologia, de Charles Lyell, o acontecimento responsável pela substituição do tempo bíblico pelo tempo geológico (de mudanças lentas, provocadas por causas naturais durante longos períodos), sem no entanto excluir o contributo de Darwin e das ciências emergentes, considerando que todos estes fatores contribuem para a erosão de uma conceção de tempo estático ou cíclico, impossibilitando qualquer noção de tempo original ou de teleologia.

A partir de finais do século XIX, com o contributo das mais diversas áreas e ciências emergentes e em afirmação, as ideias de princípio e fim, de origem e finalidade, são substituídas pelo conceito de evolução, de uma inevitável mudança gradual e irreversível ao longo do tempo. O Universo continua a funcionar com leis, mas deixa de obedecer a qualquer plano ou propósito. A existência humana passa a ser vista como um acaso e a humanidade passa a depender apenas de si própria. Como resume Scholes (1975:43), esta visão estruturalista faz da existência humana um acontecimento aleatório, num mundo regido por leis às quais o homem tem de obedecer, mas que não lhe oferecem qualquer propósito nem garantia de triunfo enquanto espécie. O futuro é uma consequência do presente que, por sua vez, resulta de um passado aleatório. Não há plano nem 
objetivo prévio. O futuro está em aberto e não tem um rumo definido. É uma narrativa em construção. Prevê-lo deixa de ser tarefa de cientistas ou profetas. Qualquer um o pode antecipar, usando apenas como ferramentas a razão e/ou a imaginação. Vários são os autores que consideram que a ficção científica resulta, em larga medida, desta expansão temporal e, usando as palavras de Mark Rose (1981:37), do "choque cultural provocado pela descoberta da posição marginal da humanidade no cosmos".

A ficção científica nasce num momento histórico em que a única regra é a mudança constante. Num mundo assim, pensar o futuro é uma forma de planificação histórica. É uma forma de protesto contra a prisão do presente. Nesta perspetiva, embora voltadas para direções temporais opostas, a ficção científica e a História partilham algumas características, nomeadamente a necessidade de se mover na linha do tempo e de criar um distanciamento para compreender o presente. Partilham ainda a mesma necessidade didática ou até preventiva, mostrando, alertando, projetando cenários, apontando os erros passados e presentes para prevenir o futuro.

Um dos autores que defende a existência de uma clara relação entre a ficção científica e a História é Edward James (1994), argumentando que ambas obrigam a uma reconstituição mais ou menos ficcional do mundo real, à exploração de diversas possibilidades, recorrendo à especulação como ferramenta metódica. História e ficção científica partilham a mesma vontade de entender o tempo (passado ou futuro) e movem-se no campo das hipóteses (do que poderá ter sido ou do que poderá ser). Pode mesmo defender-se, como faz Roberts (2000), que a ficção científica não é profética mas nostálgica. Assenta num fascínio pelo passado e não pelo futuro. Para este autor a ficção científica não nos projeta para além do presente. Pelo contrário, ela conta-nos histórias do passado, sendo por isso um modo historiográfico, uma forma de escrever simbolicamente sobre o que já foi, mesmo quando o cenário é o futuro longínquo.

Este argumento parece excessivo. Talvez a ficção científica seja, na realidade, nostalgicamente profética ou profeticamente nostálgica. Ou nenhuma das duas coisas. Talvez seja apenas uma deslocação do presente. Quer se situe 'há muito tempo atrás' como no filme Star Wars, quer no século duzentos e onze como no livro Dune, a ficção científica é sempre uma 
heterocronia, um tempo outro, um desdobramento da realidade, que se situa num horizonte omnitemporal ${ }^{2}$. Um exemplo disso são as narrativas de história alternativa, um subgénero dentro da ficção científica, em que o tempo é concebido não como uma linha única mas como um número infinito de linhas paralelas, cada uma representando um presente, um passado e um futuro possíveis, lembrando que o passado já foi um presente onde se concretizaram as possibilidades que deram origem a um futuro que agora é presente.

\section{Ficção científica e sublime}

Apesar dos pontos de proximidade entre a ficção científica e a História, uma das características que as distingue é a presença do sublime, do transcendente, daquilo que está para além e para lá de nós. Esta presença manifesta-se na escolha dos títulos das primeiras revistas do género, como Astounding ou Amazing, que em si próprios prometem encontros com o fantástico e o extraordinário.

Segundo Edward James (id.:104), o sublime pode definir-se como um sentimento de desamparo e terror que surge com a consciência da fragilidade e pequenez do ser humano perante o poder e magnitude do Universo, onde, pode acrescentar-se, será provável existir o absolutamente outro, seja ele divino ou monstruoso. No entanto, esse terror é frequentemente acompanhado por outros sentimentos, como a admiração, o encantamento ou o maravilhamento, qualquer dos conceitos servindo de aproximação semântica ao intraduzivel sense of wonder, presente na ficção científica e na religião.

Muitos são os autores que defendem a existência de uma relação direta entre a ficção científica e a religião. Alguns vão mesmo mais longe, sugerindo que a ficção científica vem preencher um papel que antes cabia à

${ }^{2}$ A expressão horizonte omnitemporal (omni-temporal horizons) é usada por Darko Suvin (1979:20-21) para caracterizar o tempo da ficção científica (que partilha este horizonte omnitemporal com o tempo empírico da literatura naturalista), distinguindo-o do tempo primordial (acima do tempo) do mito, o passado fora do tempo do folktale e o tempo extra-histórico (além do tempo) da fantasia. 
religião. A racionalidade e as "verdades" científicas contribuem largamente para a erosão da fé e dos dogmas religiosos enquanto grelhas de leitura da realidade. Mas falham pela incapacidade em alimentar o sense of wonder, uma vez que contêm implícita a promessa de que o Universo pode ser descodificado e a alteridade dominada. A ficção científica recupera o temor e encantamento religiosos, traduzidos no discurso validado da ciência, projetando noutro espaço e noutro tempo algumas das características das narrativas míticas e místicas. Permite a celebração da ciência e da tecnologia e, ao mesmo tempo, o encontro com a alteridade cósmica.

O próprio movimento de fãs associado à ficção científica se aproxima do culto organizado, com rituais próprios. James $(i d$.) reforça esta ideia considerando que os fãs se sentem uma espécie de profetas do futuro, sendo possuidores de uma verdade que o homem comum ignora, dotados de um espírito missionário (necessidade de educar as pessoas para o progresso) e encontrando no espaço (ou no futuro) uma espécie de terra prometida.

Uma outra abordagem à relação entre ficção científica e religião é sugerida por Robert Scholes (1975). Para este autor a ciência e a religião partilham de uma mesma vontade de provar que a verdadeira realidade está para além do senso comum. Condicionada pelo ideal de objetividade, a ciência apenas o pode fazer socorrendo-se de uma linguagem formal e unívoca. Enquanto texto ficcional, a ficção científica é mais livre, partilhando com a religião o mesmo mecanismo narrativo, a que ele chama fabulação. A fabulação serve o objetivo de mostrar que a realidade vai além daquilo que pode ser empírica e imediatamente captado. Na ficção científica, 'ir além de' assume normalmente um sentido de deslocação (espacial ou temporal) e não de radicalidade metafísica ou transcendência divina, como acontece na religião. No entanto, no limite do infinito não é impossível encontrar Deus, deuses ou demiurgos, e muitos textos de ficção científica resultam destes encontros improváveis.

Para Tom Woodman ${ }^{3}$, a tendência para mistificar a ficção científica acentua-se na segunda metade do século xx, depois do reconhecimento de que a ciência falhara em cumprir os seus objetivos e em fornecer valores. Daí

3 Science Fiction, Religion and Transcendence, in Parrinder, 1979:110 e segs. 
que a geração de escritores de ficção científica da década de sessenta, através de movimento que fica conhecido como Nova Vaga e que reflete tendências culturais mais genéricas, oriente as suas narrações num sentido mais espiritual e místico. O mesmo autor faz também um levantamento dos temas onde ficção científica e religião se intersetam: o encontro com a diferença, a compreensão do cosmos, os limites da ciência (éticos e metodológicos), a criação da vida, as potencialidades do espírito humano e a natureza do criador.

Pode ainda referir-se o caráter religioso da ficção científica na sua forma mais concreta e menos ficcional, um dos muitos encontros da ficção científica com a realidade. Num artigo publicado no início da década de cinquenta, L. Ron Hubbard, um escritor de ficção científica sem sucesso, cria uma nova ciência a que chama science of dianetics. A dianética era um processo que servia para elevar o indivíduo a um estado mental saudável, afastando as memórias traumáticas do passado (designadas engrams), através de um processo semelhante à confissão (a que Ron Hubbard chama auditing). No final deste processo, a pessoa veria aumentado o seu vigor físico e mental, aproximando-se dos super-heróis que, por essa altura, faziam sucesso nos comics. O problema que se colocava a Hubbard para que a sua ciência fosse validada, era a dificuldade em encontrar pessoas que apresentassem os resultados desejados depois da aplicação do método. A resolução deste problema faz com que a sua 'ciência' se transforme num fenómeno religioso. Em 1952, Hubbard publica The History of Man, onde explica que as memórias traumáticas do passado (engrams) podem resultar de experiências vividas em vidas anteriores, o que dificulta o processo de limpeza e purificação. Só depois de terem sido removidos todos os engrams se poderá alcançar o estado de pureza e perfeição final, o clear total, que origina o que ele chama operating Thetan.

Na cosmogonia de Hubbard, os Thetans eram os criadores do Universo. Omnipotentes e imortais, tinham criado mundos como forma de divertimento. Quando se cansaram, abdicaram dos seus poderes para habitar alguns dos mundos que haviam criado. Esta teoria implicava que todos os humanos fossem Thetans adormecidos debaixo de múltiplas camadas de engrams, adquiridas nas sucessivas reencarnações, e cuja remoção constituiria um processo naturalmente longo e difícil. 
Apesar de não apresentar nenhum operating thetan para comprovar a sua teoria, a promessa de imortalidade e divinização foi suficiente para garantir seguidores. No Verão do ano em que publicou o artigo fundador da Dianética, já existiam quinhentos grupos de 'auditores' nos Estados Unidos. Em 1954, a designação Dianética já passara a Cientologia e oficializava-se como Igreja da Cientologia.

L. Ron Hubbard compreendeu que os ingredientes da ficção científica misturados com uma dose de misticismo, uma porção de psicologia, uma pitada de neologismos, cobertos com a promessa de poderes extraordinários e vida eterna, constituíam uma receita que atraía milhares de fiéis, mesmo depois de ter sido acusado de burla e extorsão.

Numa forma teoricamente menos elaborada e sem a mesma institucionalização, um outro culto direta ou indiretamente derivado da ficção científica, surge também nas décadas de quarenta e cinquenta do século passado: a ufologia. Desde o Verão de 1947, altura em que o empresário de Idaho, Kenneth Arnold, afirmou ter visto objetos voadores não identificados (OVNI, no original Unidentified Flying Object - UFO), que a crença nos OVNI cresceu, moldada por várias narrativas ficcionais que alimentaram a teoria da conspiração e alguma paranoia, ampliadas, elas próprias, pelos contextos sociais e políticos de cada momento. Neste caso, podemos considerar que estamos perante uma relação dialética entre a realidade e a ficção sem que esteja claro o ponto de origem: a realidade pode ter dado origem à ficção ou a ficção dado origem à realidade, mas a relação tornou-se simbiótica e permitiu a construção de grelhas de leitura em que a fronteira entre o real e o ficcional é ténue.

Em relação a esta zona de fronteira, podemos concluir, como Tom Woodman (id.), que o que liga a ficção científica e a religião é o interesse comum em transcender a realidade presente e compreender o futuro do homem, a dimensão cósmica que ambas têm e o temor que deriva de compreendermos a nossa pequenez quando contemplamos as estrelas. Mas, em última análise, estas são as características e objetivos comuns a todas as formas de conhecimento humano. É a necessidade de transcender o presente, de antecipar o futuro, de superar a pequenez, de vencer o temor, que impulsionam a humanidade no esforço de descodificar o Universo. Isto 
pode conseguir-se usando a religião, a ciência ou a ficção. Em qualquer um dos casos, acreditar nas explicações fornecidas pelas formas racionais de conhecimento ou pela ficção é sempre uma questão de fé ou de suspensão de descrença.

Dependendo da conjuntura histórica, cada uma das formas de explicação poderá beneficiar de maior credibilidade ou de maior poder. O descrédito na religião pode levar a uma maior confiança na ciência e a um refúgio na ficção. O descrédito na ciência pode conduzir a um aumento da importância da religião e da ficção como formas de organização e simplificação do real. São todas companheiras de viagem, mas a viagem assume-se muitas vezes como competição.

No entanto, nunca se trata apenas de escolher entre ciência, religião e/ou ficção. Apesar de o pensamento ocidental associar frequentemente o conceito de ciência às ciências físicas e o de religião à tradição judaico-cristã, isto corresponde cada vez menos à realidade. Dentro de cada uma das formas de apropriação do real há explicações que se confrontam e lutam pela supremacia num esforço para excluir as restantes, à imagem do que acontece por vezes entre os vários géneros ficcionais. A ficção científica, assumindo-se como forma de discurso mais ou menos marginal no interior da própria cultura popular, combina ingredientes das várias visões do mundo, constituindo-se como uma grelha alternativa de leitura que distorce a realidade que efectivamente é e projeta o que poderá ser, obrigando o leitor a reconfigurar o presente dentro de um registo epistemológico científico, mas sem abandonar o maravilhamento religioso.

\section{Ficção científica e ficção}

Mantendo o registo de transgressão de fronteira, a ficção científica é ainda habitada por outras contradições. O seu caráter híbrido, patente na combinação dos dois termos constituintes da expressão, pode ainda ser observado na análise de cada um deles.

Aparentemente a palavra ficção é relativamente unívoca, sendo pacífica a sua interpretação. Ficção é ficção. É uma mentira, em termos de corres- 
pondência com o real, narrada com suficiente verosimilhança para que se torne verdade para o leitor enquanto este mantiver o estado de suspensão de descrença. Scholes (1968) faz uma análise etimológica das palavras facto e ficção, derivadas dos verbos facere e fingere, ambos com o significado fazer (to make). No entanto, apesar da semelhança original, cada um dos verbos teve uma sorte diferente no mundo das palavras. Facere e facto ficaram associado à realidade e à verdade, enquanto fingere e ficção se associam à irrealidade e à falsidade. Esta dicotomia, segundo o autor, nunca pode ser absoluta. Para que possa sobreviver, o facto tem de se tornar ficção, tem de se tornar parte do imaginário coletivo e ser narrado. Do mesmo modo não podemos encontrar a ficção na sua forma pura. Ela é sempre uma reconfiguração de elementos reais, de factos. Daí que o facto e a ficção nunca se possam encontrar no seu estado puro e sofram sempre, em maior ou menor grau, de um processo de contaminação mútua. Por isso, a ficção não pode ser considerada em termos absolutos mas em termos relativos, contendo no seu interior vários graus. A radicalização destes graus cria uma nova dicotomia.

Desde o século XVIII que a tradição literária estabelece uma cisão entre realismo e fantasia. A classificação é feita com base na relação existente entre o mundo ficcional e o mundo empírico. Este último fornece a grelha a partir da qual podemos avaliar o grau de proximidade ou afastamento da narrativa em relação à realidade. E uma vez mais o facere impõe-se: o realismo, mais positivo e factual, mais próximo do mundo empírico, acaba por se tornar a forma literária dominante, o mainstream, a partir do qual as formas menores derivam ou se desviam.

Baseado nesta nova dicotomia, Scholes (1968) faz a distinção entre realismo (romance realista) e romance (novela fantástica), considerando que o primeiro assenta, fundamentalmente, numa questão de perceção. Constitui-se como um relato subjetivo do mundo tal como é percebido ou percecionado pelo autor. Já o romance (novela fantástica) é uma questão de visão. Implica um maior distanciamento em relação ao mundo do que aquele que é expresso pelo realista. No entanto, conclui que as grandes obras de ficção resultam da mistura entre realismo e romance, entre perceção e visão. Dentro do romance, estabelece ainda vários padrões possíveis: a ascensão 
cómica, a queda trágica (apresenta um mundo ordenado - romance), a ascensão satírica, a queda patética e a demanda anti-heróica (inverte os valores do mundo empírico, com um efeito irónico).

Do mesmo modo que considerara facto e ficção inseparáveis, Scholes (1975) vai defender que qualquer um dos modos literários falha em relação aos seus objetivos narrativos puros. O realismo porque é incapaz de relatar o mundo sem o reconfigurar, a fantasia porque não constrói sem copiar, limitando-se a distorcer o que existe. Realismo e fantasia contaminam-se: não há criação sem cópia nem cópia sem criação.

É no espaço de interceção entre o realismo e a fantasia que surge a ficção científica, um género subversivo em que a poiesis (criação) assumidamente se ancora na mimesis (imitação). Ao contrário do realismo, que pretende oferecer um retrato do mundo como ele é, ou da fantasia que pretende afirmar o que o mundo não é, a ficção científica mostra o que esse mundo poderá ser. Não parte dele para o negar (fantasia) nem para o afirmar (realismo), mas para mostrar que (e como) poderá ser diferente.

Uma das razões para isso é o facto de o horizonte da ficção científica ser omnitemporal e omniespacial, desobrigando o autor da adesão ao mundo empírico. Na realidade, obriga-o a que o mundo retratado não seja o mundo empírico. Por isso, o autor é livre para imaginar, especular e extrapolar outros tempos e outros espaços. No entanto, ao contrário da fantasia, só o pode fazer dentro dos limites do possível, do provável, do verosímil, mantendo assim a proximidade com a realidade que lhe dá origem.

A esta forma de narrativa, que se distancia da realidade na medida necessária para a poder confrontar e para explorar as diferenças provocadas por essa distância, Scholes vai chamar fabulação ou romance didático.

Fabulação é, segundo Gary Wolfe (1986), o termo usado por Scholes para designar a ficção que apresenta um mundo radicalmente descontínuo em relação ao mundo empírico, embora mantenha com ele uma relação cognitiva. Assim, a ficção científica é, mais do que uma ficção, uma fabulação, uma resposta literária à necessidade de adaptação à rapidez do desenvolvimento científico-tecnológico e à alteração das condições de vida sentidas nos últimos dois séculos. E porque reflete e responde às condições específicas de existência da época atual, à consciência de que o Universo é um 
sistema de sistemas, uma estrutura de estruturas, Scholes vai acrescentar o termo estrutural.

Para reforçar esse estatuto, Scholes $(i d$.$) acrescenta que a ascensão da$ fabulação estrutural enquanto género narrativo deriva da incapacidade das formas narrativas dominantes em fornecer os elementos necessários para a satisfação equilibrada das duas funções inerentes a qualquer ficção: a sublimação, que permite aliviar a ansiedade e as pressões do quotidiano, contribuindo para o reequilíbrio do indivíduo, e a cognição, o elemento que permite o enriquecimento e a recompensa mental. Para ele, qualquer narrativa é limitada se satisfizer apenas uma das necessidades. Os dois ingredientes têm de estar equilibrados, o que raramente acontece, uma vez que na literatura realista mainstream a cognição está muitas vezes afastada da sublimação, e nas formas literárias menores (populares) a sublimação está quase sempre desligada de qualquer elemento cognitivo. E seria neste vazio, criado pelas insuficiências das formas narrativas dominantes, que, segundo Scholes, habitaria a ficção científica (ou fabulação estrutural), o género capaz de fornecer as doses certas de sublimação e cognição, constituindo-se como uma sublimação cognitiva ou uma cognição sublimativa, dependendo da necessidade dominante.

Uma outra definição que combina os mesmos ingredientes, embora com designações e em doses diferentes, é avançada por Darko Suvin. Para Suvin (1979), a ficção científica está entre o realismo e a literatura fantástica, considerando que lhe é indispensável um elemento cognitivo sem o qual não passaria de fantasia ou conto de fadas (fairy tale). Mas, em vez de lhe chamar fabulação cognitiva, prefere a expressão literatura de distanciamento cognitivo (literature of cognitive estrangement).

O distanciamento ou estranhamento é, para Suvin, aquilo que distingue a ficção científica da ficção naturalista (realismo) que adere ao mundo empírico ou mundo zero (zero world). O termo estranhamento é usado no princípio do século pelo formalista russo Viktor Shklovsky e vulgariza-se depois de Bertolt Brecht o ter aplicado para significar a técnica de desfamiliarizar ou alienar um objeto conhecido. No entanto, John Clute (apud James, 1994:111) argumenta que na ficção científica o movimento de 
estranhamento é inverso: não se pretende alienar um objeto conhecido, mas familiarizar o desconhecido. Poderá acrescentar-se que o leitor de ficção científica faz simultaneamente os dois movimentos: familiariza o desconhecido e, nesse processo, aliena o conhecido, criando o distanciamento crítico para uma nova leitura do real.

Para Suvin, a desfamiliarização, o distanciamento, constitui o enquadramento da ficção científica, embora não o considere o único aspeto distintivo, uma vez que é partilhado com as formas narrativas ligadas à fantasia, constituindo uma categoria específica a que ele chama estranged fiction. O conceito operacional que permite distinguir a ficção científica da restante estranged fiction é o novum. Mantendo a forma etimológica original, novum serve para designar a novidade, a inovação, a mudança que permite desfamiliarizar o mundo, criando a descontinuidade ou desvio em relação ao mundo zero que vai conduzir à interpelação crítica a que Scholes chamou fabulação.

Este novum deve dominar toda a narrativa, deve promover uma mudança em todo o universo da história, deve ser hegemónico, determinando toda a lógica textual, embora possa distinguir-se quanto ao grau de magnitude, que pode ir desde uma discreta invenção tecnológica até uma diferença radical no contexto, agentes e/ou relações.

Independentemente da sua magnitude, o novum deve introduzir uma deslocação da realidade, conduzindo a um movimento de oscilação na dialética de familiarização do estranho e de estranhamento do familiar: do mundo empírico para o novum da narrativa (permitindo com isso a compreensão dos acontecimentos narrados), e da narrativa para o mundo empírico (obrigando a olhá-lo de modo diferente).

Tal como em Scholes, é neste movimento que encontramos a dimensão cognitiva da ficção científica, e é aqui também que radica a sua especificidade científica. Se o estranhamento a afasta do realismo, a cognição permite distingui-la das outras formas de fantasia.

O novum suviniano e a descontinuidade scholesiana têm de ser cognitivamente fundamentados pela lógica racional. A desfamiliarização e a fabulação são comuns a formas de literatura e pensamento que ultrapassam a superfície empírica da realidade, mostrando que há algo acima ou além da aparência das coisas, daí que Suvin mantenha a ficção científica ligada 
ao mito e à fantasia, e Scholes considere que a fabulação (dogmática) é uma das formas privilegiadas de narração religiosa. Mas, ao contrário destas formas narrativas meta-empíricas, a ficção científica fundamenta-se numa racionalidade e numa metodologia de tipo científico, escapando assim à metafísica. É neste aspeto que radica a grande diferença entre os universos da ficção científica e os da fantasia, onde tudo é possível por escapar de forma absoluta aos limites e leis do mundo empírico.

Suvin postula, assim, que a ficção científica não é fantasia, mas também, e principalmente, que nem toda a ficção científica é ficção científica, ou seja, que nem toda a ficção científica é literatura de distanciamento cognitivo, como já Scholes afirmara que nem toda a ficção científica era fabulação estrutural.

\section{Ficção científica e ciência}

A presença do sublime, de um horizonte omnitemporal e o doseamento entre realismo e fantasia de modo a permitir um distanciamento e um olhar crítico sobre a realidade, são os requisitos até agora estabelecidos para poder classificar uma narrativa como ficção científica. No entanto, é na dimensão científica que reside a sua maior especificidade.

Ficção científica é uma expressão que traduz um encontro aparentemente improvável entre elementos opostos: a fantasia e a racionalidade, a imaginação e a realidade, o encantamento e a crítica. Mas os primeiros assentam nos segundos. Usando a terminologia de Suvin, a ficção só poderá ser científica se o novum introduzido for cientificamente credível. Quando os nova não obedecem às leis ou metodologias científicas, a ficção resultante não tem relevância cognitiva. Os produtos desse processo são, normalmente, as fantasias científicas ou os romances de aventuras que se passam no espaço, também eles produtos de fronteira, também eles populares, em que os ícones da ficção científica estão frequentemente presentes, mas com um papel meramente decorativo, uma vez que não obrigam a qualquer distanciamento crítico e se afirmam como produtos de entretenimento, com função sublimativa.

É evidente que a exigência de cientificidade da ficção científica lhe advém do contexto em que nasce. Enquanto género, constitui-se e consolida-se 
entre finais do século XIX e meados do século Xx, época de forte desenvolvimento científico e tecnológico e de reconfiguração paradigmática em que a ciência se impõe como o horizonte a partir do qual o futuro pode ser imaginado.

Partindo deste pressuposto, pode argumentar-se que, em termos históricos e narrativos, talvez a ficção científica devesse chamar-se com mais propriedade ficção tecnológica. Na realidade, são os instrumentos, os aparelhos e as descobertas que inspiram muita da ficção científica produzida no seu período áureo, enquanto o processo científico de investigar e descobrir, que se encontra frequentemente associado às múltiplas versões de Victor Frankenstein, o cientista solitário e louco que, no escuro do seu laboratório, muitas vezes inconsciente e inadvertidamente, coloca em perigo a humanidade com as suas descobertas, traduz desconfiança relativamente à ciência.

A tecnologia, com naves velozes, brilhos metálicos, luzes coloridas e raios laser, tem uma dimensão de encantamento quase mágico. Os instrumentos tecnológicos são manipuláveis e domesticáveis. São extensões de poder que atraem e seduzem. Já a ciência, com as suas fórmulas incompreensíveis e metodologia rigorosa, é hermética. Inacessível e incompreensível para o ser humano comum, inspira mais temor do que fascínio. E, talvez por isso, grande parte da ficção científica é quase anticientífica, cumprindo a função epistemológica de obrigar à reflexão sobre os limites e perigos do avanço da ciência, principalmente depois da Segunda Guerra, quando a ficção científica começa a gerar cenários catastróficos e apocalípticos.

Pode ainda considerar-se que até meados do século xx domina uma ficção científica naturalista e física, a hard sci-fi, e que a partir da década de sessenta predomina uma ficção mais soft, de cariz antropológico, sociológico e psicológico, que encontra nas ciências sociais e humanas o seu fundamento.

Mas a relação entre ficção científica e ciência não se esgota numa análise do paralelismo entre a sua evolução enquanto género e a ascensão da ciência enquanto forma dominante de conhecimento e apropriação do mundo, nem na comparação entre ciência e tecnologia ou entre ciências físicas e ciências sociais e humanas.

Quer Hugo Gernsback, quer John W. Campbell, editores das revistas fundadoras da ficção científica enquanto género narrativo, consideram que ela 
tem uma função pedagógica e educativa, ajudando as pessoas comuns a perceber a ciência e a perspetivarem o modo como esta pode moldar o futuro. Campbell vai mais longe, considerando que ficção científica e ciência são duas faces da mesma moeda, usando ambas, interativamente, a imaginação para explorar os limites do Universo. Ficção científica e ciência funcionam imaginativamente partindo de hipóteses, de um feixe de possibilidades daquilo que poderá vir a ser criado ou verificado, esbatendo as fronteiras entre o real e o imaginário. Esta correlação é clara nas primeiras gerações de escritores de ficção científica norte-americana, que provinham das ciências físicas. Muitos eram mesmo cientistas, técnicos ou, no mínimo, consumidores assíduos de revistas científicas, que depois partem dos conhecimentos científicos e os expandem imaginativamente na forma de narrativa ficcional.

Um sinal inequívoco da irrupção da ficção científica na realidade dá-se no início da década de 1980, quando um grupo de escritores de ficção científica, do qual faziam parte Robert Heinlein, Gregory Benford e Poul Anderson, formam um comité oficial de aconselhamento científico para a política espacial norte-americana (o Citizen's Advisory Council on National Space Policy), que aconselha o presidente Ronald Reagan a promover a estratégia defensiva que ficou conhecida como Star Wars, um dos programas militares mais caros de sempre, lançado em 1983 e desativado dez anos mais tarde.

Há outro paralelismo que se pode estabelecer entre a ficção científica e a ciência, nomeadamente ao nível da metodologia. Ambas se constituem como experiências mentais que partem de um 'e se?'. No caso da ficção científica, o novum funciona como variável que permite a formulação da hipótese a partir da qual é projetado o universo ficcional, por extrapolação.

A extrapolação é, basicamente, um procedimento lógico e linear em que se aceita a realidade presente para a projetar no espaço ou no tempo, imaginando as articulações daí resultantes. Apesar da popularidade do termo e da sua adoção imediata pela comunidade de ficção científica, alguns autores consideram-no redutor e restritivo, afirmando que muita ficção científica assenta noutro tipo de operações mentais. Em alternativa, sugerem a especulação, propondo que a ficção científica passasse a assumir a designação de ficção especulativa. Em 1966, Judith Merril chega a propor que a sigla SF (science fiction) passasse a designar ficção especulativa (speculative 
fiction). Esta proposta ganha alguns adeptos na nova geração de escritores e críticos, principalmente por criar uma descontinuidade com a tradição da ficção científica popular, de caráter novelístico, associado às revistas periódicas conhecidas por pulp fiction.

A especulação caracteriza-se por ser uma operação mental mais imaginativa do que a extrapolação, assente num desejo maior de transcender a realidade existente. De acordo com Malmgren (id.), a especulação opera metaforicamente enquanto a extrapolação funciona metonimicamente. Na especulação, o sistema de correspondência entre o mundo empírico e o mundo ficcional não é direto. No seu limite, deveria fornecer um Universo sem vestígios de antropomorfismo e antropocentrismo, o que é impossível uma vez que o ser humano não tem capacidade de representar o radicalmente estranho. Nessa medida, a especulação é sempre relativa e nunca perde de vista o mundo empírico, o que pode levar-nos a considerar que a diferença entre as duas operações é mais de grau do que de tipo. Ambas criam o estranhamento que Suvin refere. O que as poderá distinguir é a distância cognitiva que impõem à leitura.

A transição de uma definição da ficção científica como essencialmente extrapolativa para uma ficção dominantemente especulativa parece estar associada à já referida passagem de um domínio das temáticas ligadas às ciências físicas para reflexões mais próximas das ciências humanas que, embora mantenham a necessidade de coerência e racionalidade, fornecem uma liberdade que a objetividade das ciências duras (hard sciences) impede.

Em qualquer dos casos, quer se trate de hard ou de $s o f t S F$, quer se opere por extrapolação quer por especulação, a ficção científica está, por definição, obrigada a criar mundos epistemologicamente e ontologicamente consistentes, sendo este o aspeto essencial em que radica a sua cientificidade e, consequentemente, a especificidade da sua narrativa ficcional.

\section{Ficção científica e fantasia}

O caráter marcadamente científico que está na sua génese da ficção científica, na sua história e mesmo na formação dos respetivos autores, obriga-a 
a constituir-se como um prolongamento epistemológico do conhecimento existente. Deve apresentar uma mudança (novum) que não constitua uma rutura, mas uma extensão possível das técnicas e teorias existentes no presente. A sua credibilidade está fundada nessa continuidade, na capacidade de antecipar futuros a partir das premissas que o presente fornece. No entanto, muita da ficção que se considera científica vai além das possibilidades aceites ou aceitáveis, transgredindo a lógica, a ciência e, por vezes, até o mais elementar senso comum, caindo por isso fora dos limites do conceito.

Este tipo de narrativas, que submetem os princípios racionais às estratégias sublimativas, frequentemente mantêm o tom do discurso científico. Recorrem, para isso, a um conjunto de dispositivos textuais partilhados capazes de garantir uma pseudorracionalidade e aparência de cientificidade, cujos exemplos mais comuns são a hipervelocidade (o space warp), que permite atravessar galáxias sem que decorram centenas de anos, ou a máquina de tradução, que permite compreender instantaneamente uma linguagem alienígena. Estes dispositivos narrativos, a que Rose (1976) chama flim-flam, originam as narrativas que Suvin classificou como não cognitivas pela sua banalidade ou incoerência. São formas híbridas, que combinam elementos dos vários tipos de ficção popular, dando origem ao subgénero que ficou conhecido nos Estados Unidos da América como space opera ou science adventure SF.

A expressão space opera (que se poderá traduzir livremente por novela espacial) foi criada, em 1941, por Wilson Tucker, que acrescenta às horse operas (westerns) e soap operas (novelas ou melodramas românticos) que entretinham a classe média norte-americana, um novo género de ficção que envolvia naves em longas viagens intergaláticas para zonas desconhecidas (roubando à ficção náutica muita da terminologia e temática), aventuras excitantes, confronto entre o bem e o mal, um enredo simples, personagens planas e a repetição das fórmulas de sucesso utilizadas nos outros géneros narrativos populares, como policiais ou westerns. Frequentemente, os enredos giram em torno de piratas que ameaçam os navegantes espaciais, aventureiros à procura de riqueza em galáxias desconhecidas, agentes interplanetários que perseguem génios do mal, e, invariavelmente, um herói masculino corajoso e uma personagem feminina em perigo. 
Pode considerar-se que, neste tipo de história, a ciência, os seus dispositivos e possibilidades são explorados como mero pretexto, ou, no melhor dos casos, como contexto ou cenário em que decorrem aventuras espetaculares.

Alguns autores apresentam argumentos em defesa da ficção pseudocientífica, considerando que os artifícios usados para superar a grelha de possibilidades que a ciência impõe poderão ser hoje implausíveis, mas que não se podem excluir, visto que os pressupostos científicos atuais podem estar errados. Além disso, estes dispositivos permitem explorar espaços, tempos, contextos e relações que de outro modo estariam vedadas aos criadores de ficção científica. Gary Westfahl (2003) acrescenta ainda que, apesar da pobreza narrativa das space operas, estas serviram o propósito de introduzir os leitores na ficção científica enquanto género literário, preparando-os para apreciar os trabalhos mais elaborados e exigentes que se seguiriam.

Um outro tipo de narrativa de fronteira que levanta o mesmo tipo de questões em relação ao rigor científico é a fantasia científica (science fantasy). De acordo com Peter Nicholls e John Clute (1993), o conceito nunca foi claramente definido. Foi classificado como um género híbrido onde se misturam elementos da ficção científica e da fantasia, distinguindo-se dos subgéneros espada e magia (sword and sorcery) e fantasia heroica (beroic fantasy) por não conter necessariamente magia, deuses e demónios, embora estes ingredientes possam aparecer numa forma mais racionalizada de modo a caberem num enquadramento científico.

À imagem da ficção científica, a fantasia científica assume a existência de um Universo regido por leis naturais, regulares, numa aceitação aparente da validade da episteme científica. O que distingue a fantasia científica é a irrupção de um ou mais elementos sobrenaturais na superfície aparentemente neutra dos factos, violando leis, contrariando dados empíricos e jogando com os sentimentos que a sobrenaturalidade e irracionalidade provocam no ser humano. O novum existe, o estranhamento acontece, mas a dimensão cognitiva não é satisfeita, explorando-se, em seu lugar, aspetos místicos ou meramente imaginativos.

Segundo Malmgren (1991), o mundo da fantasia científica pode violar cinco tipos diferentes de garantias científicas: a própria epistemologia da 
ciência (quando pressupõe a existência da magia como modo de relação com o mundo), uma teoria científica aceite (quando escolhe ignorar determinados princípios científicos básicos como a unidirecionalidade do tempo), um dado científico aceite (como a impossibilidade de vida humanoide em Marte), um facto histórico (quando assume linhas temporais alternativas) ou uma possibilidade de atuação (quando introduzem entidades cuja morfologia, poderes ou a própria existência contrariam as possibilidades científicas).

Ao fazer esta caracterização tipológica da fantasia científica, Malmgren esvazia a ficção científica da maior parte das temáticas que lhe são usualmente atribuídas. No entanto, ao contrário de muitos autores que veem a fantasia científica como uma forma de ficção não cognitiva, em que a racionalidade científica é usada para mascarar uma infração grosseira às leis naturais e aos dados empíricos, considera que é exatamente na área de intersecção entre a ficção científica, que trata do conhecido e do desconhecido, e da fantasia, que trata do real e do irreal, que se encontram as maiores potencialidades temáticas, a possibilidade de mobilizar diferentes protocolos de leitura e a satisfação simultânea das necessidades cognitiva e sublimativa. O mesmo autor considera ainda que é a partir da intromissão do fantástico que a ciência pode ser questionada como forma (dominante) de apreensão, compreensão e apropriação do real.

Apesar da instabilidade conceptual da fantasia científica e da dificuldade em traçar fronteiras claras entre ficção e fantasia científicas, é aparentemente consensual que a segunda, exatamente pela presença de um elemento não natural, possui uma dimensão mais afetiva, mais emocional, caindo muitas vezes no maniqueísmo moral característico da fantasia.

Fantasia científica e novela espacial, unidas no mesmo desrespeito pelos princípios científicos e racionais, assumem-se normalmente como um subproduto da ficção científica, característico de determinados momentos históricos. No entanto, frequentemente dão origem a narrativas de sucesso. Um caso exemplar é o filme Star Wars (George Lucas, 1977), que origina duas sequelas nos anos que se seguem e três prequelas duas décadas depois ${ }^{4}$.

\footnotetext{
4 Nos títulos originais: The Empire Strikes Back (Irvin Kershner, 1980), The Return of The Jedi (Richard Marquand, 1983), The Phantom Menace (George Lucas, 1999), Attack of the Clones (George Lucas, 2002) e Revenge of the Sith (George Lucas, 2005).
} 
A dimensão científica (naves, robôs e androides, armas de destruição maciça, alienígenas exóticos) serve para acentuar a espetacularidade dos cenários onde decorrem as aventuras e onde se confrontam as forças do bem e do mal, a luz e as trevas, envolvendo uma dimensão mágica e sobrenatural.

Apesar de ter contribuído largamente para a implantação da ficção científica enquanto género cinematográfico, a grande vantagem da saga Star Wars em relação a outros filmes reside no aspeto ficcional e não no aspeto científico ou cognitivo, sendo as possibilidades científicas frequentemente usadas como pretexto para a espetacularidade, exploradas apenas na medida que estendem horizontes e aumentam a escala.

Embora sejam vulgarmente classificadas como ficção científica, é frequente encontrar narrativas que excedem e violam os princípios da própria ciência, questionam e problematizam os seus limites e consequências e, muitas vezes, a usam como mero cenário ou dispositivo epistemologicamente inútil. De facto, a ficção científica pode aparecer numa forma pseudo, anti ou até acientífica (quando a ciência não é contexto nem pretexto, como acontece nas narrativas de história alternativa). Mas, em qualquer dos casos, desenha-se sempre sobre (ou contra) um fundo epistemológico em que (ainda) domina a fé na razão, nos princípios lógicos, nos dados empíricos, na invariabilidade das leis e na capacidade de descodificar e interpretar o mundo. O discurso da ficção científica é, como na ciência, o da possibilidade, da plausibilidade, da verosimilhança, da probabilidade, da concretude, embora, como afirma Roberts (2000), o movimento da ficção científica vá cada vez mais no sentido da fabulação, de uma reconfiguração simbólica do mundo, afastando-se da dimensão estrutural. Talvez possamos resumir esta ideia dizendo que a ciência aparece cada vez menos como contexto ou pretexto e cada vez mais como subtexto. 


\section{HISTÓRIA DA FICÇÃO CIENTÍFICA}

\section{Enquadramento Histórico}

Uma melhor compreensão da ficção científica como fenómeno cultural que expressa os cruzamentos e contradições referidos anteriormente obriga a um percurso pela sua história. Mas dada a complexidade do género é possível traçar múltiplas genealogias, ligadas a vários géneros e subgéneros narrativos. A tradição helenística, o romance medieval, a literatura de viagens extraordinárias e imaginárias, as utopias humanistas, os romances góticos, os contos filosóficos e as lendas podem encontrar-se numa arqueologia do género.

Do ponto de vista literário, este fenómeno de confluência é absolutamente natural uma vez que os géneros narrativos nascem sempre de géneros anteriores, num movimento de fusão e transformação que os adapta a novos contextos históricos. E no caso da ficção científica, a alteração rápida das circunstâncias históricas impulsiona este movimento de extensão e adaptação de velhas fórmulas narrativas a novas realidades. O rápido desenvolvimento científico e tecnológico e a progressiva laicização do mundo ocidental são, claramente, os fatores histórico-culturais que, desde a sua génese, mais contribuem para a sua afirmação enquanto género. Estabelecida esta premissa, torna-se necessário encontrar as influências mais subtis.

\section{Raízes da ficção científica}

As evoluções científicas e tecnológicas, que caracterizam a revolução industrial, criaram novos modos de produção, novas formas de organização 
social e uma reorganização geográfica. Homens e mulheres ocidentais deslocam-se para as grandes cidades onde, como resume Rose (1981:53), vivem desligados de Deus, da natureza e dos outros seres humanos, num estado de solidão espiritual que se prolonga até aos nossos dias. Neste contexto, o aparecimento e desenvolvimento da ficção científica poderá ser entendido como uma forma de restabelecimento dos canais de comunicação entre o humano e o transcendente, num esforço de dar sentido a um universo cada vez mais estranho e independente, utilizando para isso a validade da episteme científica vigente.

Roberts (2000) argumenta num outro sentido, salientando que a ficção científica surge na época dos grandes impérios e por isso não consiste numa procura do outro naquilo que de próximo e semelhante pode trazer, mas resulta da necessidade de esbater, erradicar ou domesticar a diferença. A ficção científica seria, nesta perspetiva, uma expressão subconsciente da ideologia imperial, quer se trate dos impérios coloniais do século XIX, quer da hegemonia cultural norte-americana do século xx.

Já para Thomas Clareson (1990), a ficção científica é essencialmente o resultado de uma tradição literária que tem origem no Renascimento, provocada por um aumento da atenção ao mundo físico (realçando o fascínio pela expansão marítima e interesse na astronomia de Copérnico) que contribui para a abertura de novos horizontes e perspetivas. Considera ainda que o género resulta do confluir de várias influências: a literatura de viagem extraordinária aparecida em finais do século XVII, a utopia humanista, o romance gótico com a sua dimensão de horror, a temática das guerras futuras que se desenvolve a partir de finais de XIX como resposta ao crescente armamento das potências europeias imperialistas, e as narrativas populares das dime novels norte-americanas onde se desenhava uma crescente admiração pelos cientistas e suas criações.

Aos fatores enunciados podemos acrescentar outros que derivam diretamente dos avanços nas várias ciências e da velocidade do progresso tecnológico que, no final do século XIX, impõem novas conceções de tempo, de espaço e de humanidade.

A laicização do cosmos, a descoberta de novas culturas, o crescimento das cidades, o avanço da ciência e da tecnologia, as novas referências 
temporais e uma nova conceção de humanidade, são fenómenos que vão contribuir para simultaneamente delimitar e estender horizontes que permitem pensar, heterotopica e heterocronicamente ${ }^{5}$, novas formas de alteridade, novas combinações entre o familiar e o estranho, entre o descoberto e o que ainda estava para descobrir.

É no contexto destas múltiplas transformações que começa a surgir uma protoficção científica, designação atribuída aos trabalhos que, contendo já alguns elementos distintivos, antecedem a existência do género, sendo por isso classificados retrospetivamente. Nestes esboços iniciais da ficção científica encontram-se textos provenientes de múltiplas tradições literárias. Em 1516, Thomas More publica Utopia, um texto que descreve uma ilha redonda, idêntica ao Reino Unido, com recursos naturais semelhantes e uma economia baseada na agricultura. O seu regime político é a democracia, não existe propriedade privada, a riqueza é desprezada e a população é feliz. Além do termo utopia, Thomas More deixa como legado a ser explorado pela ficção científica o método de reflexão crítica sobre a realidade concreta através de realidades imaginadas, sem o recurso a dispositivos místicos ou mágicos.

No século XVII, como resultado da contínua expansão do mundo conhecido, começam a surgir múltiplos relatos de viagens extraordinárias e imaginárias que Brian Stableford (2003) classifica como fantasias utópicas, de que é exemplo New Atlantis (escrita em 1617, publicada em 1627) de Francis Bacon, fantasias satíricas, como no caso de Gulliver's Travels (1726) de Jonathan Swift, ou viagens fantásticas interplanetárias, como L'Autre Monde (publicação de alguns fragmentos em 1657 e 1662), de Cyrano de Bergerac.

Para Stableford, o grande problema destas narrativas era a ausência de um dispositivo que lhes permitisse dilatar as fronteiras do espaço e, principalmente, do tempo. O sonho ou o sono eram o único meio plausível de aceder ao futuro e as estruturas narrativas ficcionais tradicionais impediam a especulação séria sobre as implicações do presente. Por isso, realça a

5 Segundo Bruce Franklin (1966:144), heterotopia (lugar diferente) é um termo sugerido por Robert Plank para designar os trabalhos que retratam mundos diferentes incluindo viagens extraordinárias, utopias e distopias. Do mesmo modo heterocronia (tempo outro) poderá servir para designar os diferentes registos temporais que podem existir na ficção científica. 
obra de Edgar Allan Poe, que aponta como exemplo da procura de formas literárias para expressar a estética das descobertas científicas. Mark Hillergas ${ }^{6}$ considera que Poe é o escritor do século XIX que mais contribui para a emergência da ficção científica enquanto género antes do aparecimento de Verne e Wells, destacando as obras The Facts in the Case of M. Valdemar (1845) e The Unparalleled Adventures of One Hans Pfaal (1835).

Apesar da evolução e da diversificação temática subsequentes, talvez seja na literatura de viagem imaginária que encontramos a essência do género. A ficção científica é, em larga medida, a continuação possível das viagens extraordinárias realizadas pela humanidade, num mundo em que já não há mais espaço para descobrir ou conquistar. A atração pelo desconhecido, a vontade de encontrar e dominar a diferença, o espírito de aventura e a conquista territorial, que levaram os europeus ao novo mundo e os norte-americanos ao velho oeste, continuaram a impulsionar o ocidente para novos horizontes. E no século XIX, com a decadência dos impérios e a conquista do oeste americano, havia já a consciência (expressa no genérico da série Star Trek) de que o espaço era a derradeira fronteira. A iconografia e terminologia náutica e militar, os dispositivos tecnológicos que permitem a navegação no espaço ou no tempo são também sintomáticos desta ancoragem do género na literatura de viagem extraordinária. As metáforas da viagem e do império podem aplicar-se à própria ciência, que avança, conquista, domina e abre novos horizontes, reconfigurando os limites do desconhecido.

Num registo diferente do da viagem imaginária, Mary Shelley publica, em 1818, Frankenstein, um romance gótico que muitos apontam como a primeira obra que, retrospetivamente, se pode classificar como ficção científica. $\mathrm{Na}$ realidade, Frankenstein de Shelley é a primeira narrativa anticientífica, que expressa, na forma de romance, o medo do progresso, o encontro com o outro, os perigos da ciência, a manipulação da vida, a fronteira entre o humano e o não humano e o sentimento de solidão e alienação que se traduz no drama de uma criatura que desperta para a consciência num

6 The Literary Background to Science Fiction, in Parrinder, 1979:2-17. 
universo estranho e hostil, temas que serão a base de grande parte das narrativas do género ao longo dos séculos que se seguirão. No entanto, apesar de frequentemente se apontar Frankenstein como o texto fundador, vários autores consideram que os verdadeiros pais do género são Jules Verne e Herbert George Wells, não só pelas características das narrativas que produzem, mas também pela quantidade de obras publicadas por cada um deles, reveladora de uma intencionalidade que lhes garante a continuidade e uniformidade que não se encontra na obra de Mary Shelley.

Edward James (1994) destaca a importância de Wells, considerando-o a figura central na transformação do romance científico em ficção científica por estabelecer a agenda temática em que o género assentará: a vida no futuro e a viagem no tempo (The Time Machine, 1895), a criação artificial de vida, o humano e o inumano, e o cientista louco e os perigos da ciência (The Island of Dr. Moreau, 1896; The Invisible Man, 1897), o encontro com seres alienígenas, a invasão da Terra (The War of the Worlds, 1898), a utopia (A Modern Utopia, 1905) e a distopia (When the Sleeper Wakes, 1899), inventos científicos (The New Accelerator, 1901, The Food of the Gods, 1904), guerra futura (The War in the Air, 1908) e catástrofes cósmicas (In the Days of the Comet, 1906). Aceitando-se esta paternidade, reforçada pela quantidade de adaptações cinematográficas, o nascimento da ficção científica terá ocorrido em 1895 com a publicação de Time Machine de H. G. Wells.

Apesar dos antepassados mais ou menos longínquos e de uma maternidade precoce com Mary Shelley, podemos, de facto, aceitar que é só no último terço do século XIX que emerge um conjunto de textos com características comuns, estabelecendo um sentido de género a partir do qual se começa a esboçar uma tradição. Para isso contribui a dupla paternidade de H. G. Wells e Jules Verne, que se traduz também numa dupla orientação metodológica. Em Verne encontra-se uma ficção mais extrapolativa, mais metonímica, temporalmente mais próxima do mundo real e mais preocupada em mostrar o caráter extraordinário das transformações tecnológicas, centrando-se nas criações e não nos criadores ou nos processos de criação. $\mathrm{Na}$ obra de Wells as narrativas são mais especulativas, mais metafóricas, física e temporalmente mais distantes do mundo empírico, menos preocupadas com a plausibilidade e razoabilidade científicas, mais centradas nos 
efeitos provocados pela ciência e pela tecnologia na reconfiguração da sociedade. Verne propõe, com o entusiasmo característico da literatura juvenil, um futuro otimista e brilhante, enquanto Wells desenha cenários mais cinzentos e catastróficos. A vantagem do primeiro em termos de fidelidade para com a episteme científica é compensada com a necessidade de reflexão imposta pelo novum criado pelo segundo. Independentemente das diferenças, os dois autores contribuem, de modo decisivo, para a definição e delimitação do território em que se vai fundar a ficção científica, impondo os dois tons entre os quais ela irá alternar ao longo da sua história.

Enquanto na Europa se consolida a tradição do romance científico, designação genérica que assumiram os textos de H. G. Wells e Jules Verne, a migração do género para os Estados Unidos, no início do século xx, vai originar a primeira mediamorfose da ficção científica, que aí assume um nome e uma identidade autoconsciente. O grande responsável por esta reconfiguração é Hugo Gernsback, apontado como o verdadeiro pai da ficção científica, não pelo seu talento enquanto escritor, mas como editor capaz de antecipar e construir público e mercado para este tipo de histórias.

Esta longa genealogia só fica completa com a referência a John Campbell, escritor e editor que em finais da década de 1930 vai dar uma nova orientação à ficção científica 7 .

\section{Cronologias}

Uma das formas de avaliar o impacto relativo de cada um dos autores referidos é enquadrando-os no percurso histórico do género. Partindo dos vários contributos, podem estabelecer-se cronologias evolutivas, usando como ângulos de abordagem a influência pessoal de determinados autores e editores, os temas dominantes, as circunstâncias históricas, sociais e políticas subjacentes à construção dos textos ou, como tentaremos demonstrar ao longo deste capítulo, os próprios media em que a ficção científica é difundida.

\footnotetext{
7 Para uma discussão mais detalhada das múltiplas paternidades da ficção científica, $c f$. McCracken, 1998.
} 
McCraken (1998) é um dos autores que apresenta uma periodização da ficção científica assente nas visões dominantes do mundo em cada um dos quatro momentos que considera terem marcado o género. No primeiro, anterior ao século XIX, domina a literatura fantástica e de viagem. O segundo período situa-se no século XIX e dominam as temáticas ligadas aos efeitos da revolução industrial. O terceiro vai de finais de XIX até meados do século xx e caracteriza-se pelas visões daquilo que ele designa por iluminismo científico. Por fim, um quarto período inicia-se no final do século xx e assenta nas visões de um mundo pós-moderno, pós-industrial e frequentemente pós-holocáustico.

Rose (1981) oferece uma periodização mais precisa em termos cronológicos e mais associada às personalidades que marcam o desenvolvimento da ficção científica. De acordo com ele, uma fase inicial situa-se entre 1870 e 1910, e está principalmente associada ao trabalho de Verne e Wells. Na segunda fase, que dura até meados da década 1930, assiste-se ao desenvolvimento da ficção científica enquanto forma narrativa popular norte-americana. Este momento está associado a escritores como Edgar Rice Burroughs ${ }^{8}$ e E. E. Smith, e à fundação, por Hugo Gernsback, da primeira revista especializada em ficção científica, a Amazing Stories.

Segue-se aquela que ele chama era dourada da ficção científica e que coincide com a década de 1940. Esta fase é indissociável do nome de John Campbell e do seu papel como editor da revista Astounding Stories.

A época seguinte caracteriza-se por um alargamento das temáticas que decorre ao longo da década de 1950, especialmente através do contributo das revistas Galaxy e The Magazine of Fantasy and Science Fiction, sucedendo-se um período de experimentalismo estético e temático que começa na década de sessenta e que é genericamente designado por nova vaga.

Gary Wolfe (1986) refere a cronologia proposta por Isaac Asimov e James Gunn, assente na fórmula narrativa dominante em cada período. Assim, Asimov considera que existe um período embrionário, a que chamou era

\footnotetext{
8 Edgar Rice Burroughs, mais conhecido como criador do Tarzan, foi um dos precursores da ficção científica interplanetária, com a publicação em 1912 de Under The Moon of Mars (republicado com o nome $A$ Princess of Mars), que serve de modelo para muita da ficção das décadas seguintes.
} 
primitiva, que teria decorrido entre 1815 e 1926, associada ao desenvolvimento do romance científico europeu. O período seguinte, que corresponde à importação do modelo do romance científico para os Estados Unidos e à sua consolidação como forma narrativa popular, traduz-se numa ficção científica em que o elemento dominante é a aventura e que vigora ao longo de toda a era Gernsback. O declínio da posição de Gernsback como editor corresponde à ascensão de Campbell, inaugurando-se, em 1938, uma nova era, a era Campbell, em que a tecnologia é o aspeto dominante nas narrativas.

A década de 1950, em que Asimov propõe esta cronologia, marca o fim da era Campbell e origina uma ficção científica em que o aspeto dominante é o social. Posteriormente, James Gunn acrescenta um quarto período, mais marcado pelo estilo narrativo, e que decorre a partir de meados de 1960, correspondendo à nova vaga na ficção científica.

Por seu lado, Clareson (id.) vai considerar a história da ficção científica indissociável da história norte-americana e, por isso, determina a agenda temática de cada período a partir da realidade social e política dos Estados Unidos. Considera que a década de 1930 e início da década de 1940 constituem o período de consolidação do género, dominado pela ficção espacial devido à influência dos avanços na tecnologia de foguetões e da criação da American Rocket Society e da British Interplanetary Society. Num segundo momento, depois da Segunda Guerra, a ficção científica vai refletir as preocupações norte-americanas acerca dos perigos e ameaças nucleares e a temática dominante passa a ser a guerra futura e seus efeitos na civilização. Ainda neste período, ao longo da década de 1950, vão surgir também narrativas ligadas à psicologia e ao desenvolvimento dos poderes da mente (psionics), e introduz-se a temática da engenharia genética, enquanto os anos sessenta são dominados por uma preocupação com a sexualidade e com o uso de drogas.

\section{A Pulp Fiction e a consolidação da ficção científica}

Como Clareson e outros autores assumem, poderemos realmente considerar que a realidade empírica de que a ficção científica parte tem sido a 
realidade dos Estados Unidos da América, e que os momentos da ficção científica implicam, afirmando ou negando, as várias noções de americanidade.

No entanto, como já foi referido, as suas raízes literárias encontram-se na Europa, especificamente no Reino Unido com Shelley e Wells, e em França com Verne. Pode, por isso, afirmar-se que uma primeira transformação se dá quando os temas do romance científico se deslocam para uma forma narrativa mais popular que lhe confere uma identidade e estatuto diferente daquele que poderia ter assumido se tivesse continuado como uma derivação do romance mainstream.

Uma das formas de abordagem a esta questão consiste em olhar para as políticas de publicação que vigoravam em cada um dos lados do Atlântico no início do século xx. No Reino Unido, por exemplo, dominava a publicação em três volumes, o three-decker, que obrigava a uma certa consistência narrativa e qualidade literária. O romance científico era publicado em capa dura (hardback), e herdara de Wells respeitabilidade literária e a seriedade com que abordava os temas ligados ao futuro.

Enquanto Wells e outros autores como George Bernard Shaw, Olaf Stapledon e Aldous Huxley, continuam a publicar histórias científicas em hardback, refletindo de um modo profundo e num tom relativamente sombrio sobre o futuro mais ou menos próximo (uma das temáticas dominantes é a distopia social, política e/ou científica), nos Estados Unidos a literatura inventa fórmulas narrativas e formas de divulgação adequadas ao sonho americano e a um mercado em expansão.

A descoberta de um tipo de papel feito de polpa de madeira, mais barato e de menor qualidade, vai levar a um aumento do número de publicações de revistas que ficaram genericamente conhecidas por pulp magazines. ${ }^{9}$

A consolidação da ficção científica enquanto género resulta da sua migração, não apenas da Europa para os Estados Unidos, mas essencialmente do hardback para as revistas pulp. Daí que se possa considerar que a história da ficção científica está, desde a sua génese, intimamente ligada ao medium em que é veiculada.

9 Este tipo de revistas existia desde 1896, altura em que Frank Munsey transforma uma revista infantil (a Golden Ardosy) numa revista destinada a todo o tipo de ficção. 
As pulp começaram a diferenciar públicos e a especializar-se em franjas temáticas. De acordo com McCracken (1998), surgem quatro modelos de histórias: a história de amor, dirigida a um público feminino, os westerns para uma audiência tipicamente masculina, o policial e, inicialmente mais raras, as aventuras exóticas passadas em civilizações perdidas ou noutros planetas, de que eram exemplo as histórias de Edgar Rice Burroughs e Abraham Merritt.

Uma das primeiras pulp a dedicar-se a um tipo de histórias mais fantásticas, num cruzamento entre a ciência e o sobrenatural, foi a Weird Tales, lançada em 1923. Mas só três anos mais tarde, com o lançamento da Amazing Stories por Hugo Gernsback, é que a ficção científica começa a impor-se como um tipo narrativo específico, com designação, identidade e objetivo.

A carreira de Hugo Gernsback começa em 1908, na revista científica Modern Electrics. A sua função era interessar e educar o público para os desenvolvimentos nas comunicações eletrónicas, nomeadamente para a rádio. Depois de vender a sua parte na Modern Electrics, vai criar uma publicação semelhante chamada Electrical Experimenter, que passa a designar-se Science and Invention em 1920, onde já era publicada alguma ficção de cariz científico.

Com a criação da Amazing Stories em 1926, Gernsback passa do relato dos factos científicos ou tecnológicos para a ficção, sem perder de vista o objetivo pedagógico em relação à ciência. Os primeiros dois números são dedicados a Wells, Verne e Poe, ajudando a definir a linhagem e o tom do género emergente. Contribui ainda para a criação de uma noção de comunidade, solicitando a participação ativa dos leitores. Em pouco tempo (a Amazing Stories publicou trinta e sete edições antes de falir em 1929), Gernsback tornou a ficção científica num mercado viável e atrativo para outras revistas que se vão estabelecendo dentro do género.

A sua influência na construção da identidade da ficção científica norte-americana é tanta que dá origem à expressão gernsback era para classificar o período entre 1926 e 1938, anos em que Campbell exerce a sua influência como editor. Podemos considerar que é nesta fase que o romance científico e as viagens extraordinárias se transformam em ficção científica ou, na designação inicialmente proposta por Gernsback, scientifiction. 
Apesar das intenções didáticas em fornecer uma lição de ciência disfarçada de aventura (uma cognição sublimativa), o que vai acontecer na Era Gernsback é mais ou menos o contrário, ou seja, são criadas aventuras em que a ciência serve apenas de cenário ou de pretexto. Um dos autores mais representativos desta fase da evolução da ficção científica é E. E. 'Doc' Smith, doutorado em ciência alimentar, cujas novelas se caracterizavam pelos cenários exóticos e imaginação colorida, como acontece em The Skylark of Space, publicado na Amazing Stories em 1928. Na realidade, é a ele que é atribuída a origem da novela espacial que, como Clareson (id.) refere, é uma espécie de adaptação do western à escala cósmica. É por esta altura que se vai agravar a dicotomia entre uma ficção científica europeia e uma ficção científica norte-americana. Baird Searles et al. (1980) consideram que a diferença entre a escola inglesa e a escola norte-americana se pode resumir às dicotomias reflexão/aventura, intelecto/emoção, apolíneo/ dionisíaco, stuff/nonsense ou, usando a terminologia de Brian Aldiss, entre pensadores e sonhadores.

Hugo Gernsback ocupa um lugar histórico na formação da ficção científica norte-americana. Contudo, depois da década de cinquenta, as referência a Gernsback tornam-se pejorativas. Enquanto Hugo era usado para designar os prémios atribuídos anualmente aos melhores livros de ficção científica (os Hugo Awards), numa clara homenagem, gernsback dá origem a um adjetivo que serve para caracterizar o tipo de narrativas pobres, sem reflexões sociais, frequentemente centradas nos aparelhos tecnológicos ou nas aventuras dos heróis, e, contrariamente aos objetivos pedagógicos de Gernsback, com pouca credibilidade científica.

Além disso, é a Gernsback que se devem também alguns dos excessos de autoconsciência que funcionaram como elementos marginalizadores do género, como o envolvimento ativo dos fãs, os encontros, as convenções e os prémios, levando alguns a considerar que teria sido melhor para a ficção científica ter-se mantido fiel à tradição europeia, em formato de romance, afirmando-se como uma variante da literatura mainstream.

Entretanto, na Europa, a publicação de ficção científica continuava a fazer-se, embora esporadicamente e sem ter adquirido a identidade e o sentido de tradição que começava a ganhar nos Estados Unidos. A primeira Guerra 
Mundial contribui para criar um hiato na publicação, um espaço que os americanos rapidamente ocupam com as suas revistas coloridas e fórmulas narrativas atrativas. A partir da década de 1940, os escritores britânicos começam a escrever diretamente para as revistas norte-americanas, enquanto as poucas revistas britânicas especializadas em ficção científica (Tales of Wonder, New Worlds e Science Fantasy) publicavam também autores americanos, fundindo-se as duas tradições geográfica e culturalmente diferentes por ação de um meio de difusão comum.

Nos Estados Unidos, a partir da década de 1930 o género está claramente definido. O contexto histórico é favorável ao seu desenvolvimento e expansão. O domínio americano em relação ao resto do mundo parece claro, e a ciência e o espaço assumem-se como fronteiras últimas a conquistar. Apesar de não gozar do prestígio literário que mantém na Europa, a ficção científica norte-americana torna-se um género com imensa popularidade que exerce fascínio essencialmente nos leitores mais jovens.

No início da década de 1930, estimuladas pelo sucesso da Amazing Stories, começam a surgir várias revistas, como a Science Wonder Stories, lançada em 1929 pelo próprio Hugo Gernsback que entretanto perdera o controlo da Amazing, a Astounding Stories (1930), a Astonishing Stories (1931) e a Marvel Science Stories (1938).

Das múltiplas revistas que surgem nesta época, é a Astounding Stories que vai assumir maior protagonismo durante as décadas seguintes. Em 1933, o seu editor, Orlin Tremaine, consciente de um certo esgotamento das fórmulas narrativas habituais, sugeriu que os escritores apresentassem aquilo que ele chamou histórias de pensamento alternativo (thought variant stories), com maior densidade especulativa e maior ênfase aos efeitos da ciência e da tecnologia na sociedade ${ }^{10}$. Com isso vai dar início a um segundo movimento de transformação da ficção científica.

$10 \mathrm{Um}$ dos exemplos apontados como thought variant story é Who Goes There?, de John Campbell que virá a ter grande protagonismo como editor da Astounding Stories, publicado em 1938 e adaptado ao cinema em 1951 (The Thing - From Another World, Nyby), 1982 (The Thing, Carpenter), e em 2011 (The Thing, Van Heijningen Jr), em que o tema dominante é o confronto da ciência (grupo de cientistas) com o outro (alienígena), que se traduz também num encontro com as seus próprios limites. 
A transição para uma nova fase dá-se verdadeiramente com John Campbell, que se torna editor da Astounding Stories em 1937. Campbell pediu aos escritores que as suas histórias tivessem um fundamento científico mais sólido e encorajou uma nova geração a escrever. Por outro lado, adotou uma imagem mais sóbria, evitando as capas coloridas com monstros e naves e mudou o nome de Astounding Stories para Astounding Science Fiction, assumindo a designação criada por Hugo Gernsback.

No entanto, apesar do espírito inovador, a era de Campbell mantém alguma continuidade com a linha definida por Gernsback, não apenas no medium e no conteúdo ficcional, mas também no encorajamento de uma participação efetiva por parte dos leitores, com a publicação de cartas que representam uma forma de autocrítica do género e ajudam a moldar a ficção científica, e a promoção de encontros e convenções, transformando o envolvimento dos fãs num dos traços mais distintivos da ficção científica.

Com as transformações introduzidas, Campbell vai fazer com que a ficção científica entre no período que é genericamente designado por era dourada e que dura até ao início da década de cinquenta. Era dourada e era Campbell são expressões frequentemente utilizadas como sinónimo, e servem para designar o período em que a ficção científica se caracteriza por um aumento da qualidade narrativa, do cuidado em relação aos detalhes científicos e por uma maior reflexão sobre as implicações da evolução científica e tecnológica na sociedade, continuando a alargar o seu público alvo. Isaac Asimov, Robert Heinlein, Alfred Bester, Theodore Sturgeon são alguns dos escritores desta era, que, segundo McCracken corresponde ao iluminismo científico, concretizado em visões utópicas do progresso científico e tecnológico norte-americano, capaz de fornecer ferramentas para a descoberta e construção de um novo mundo.

\section{Nova Vaga}

A Segunda Guerra vem provocar uma alteração no tom das narrativas. O iluminismo científico norte-americano começa a dar lugar a alguma desconfiança e medo. Os cenários da ficção científica vão-se tornando cada 
vez mais apocalípticos e pós-apocalípticos. Hiroshima, Nagasaki e a tensão da Guerra Fria acentuam uma sensação de incerteza em relação ao futuro e aumenta a procura de histórias que abordem a temática nuclear. Novos leitores chegam à ficção científica à procura de explicações para as perplexidades do mundo em que vivem, e o mercando expande-se.

Enquanto a paranoia política se projeta na ficção científica em narrativas de invasão, há simultaneamente um movimento de aproximação temática às ciências humanas, como a História, a Sociologia e a Psicologia. Esta última origina um tipo de narrativas que explora as potencialidades dos poderes psíquicos, como telepatia, telecinesia e perceções extrassensoriais (psionics).

Por esta altura, uma nova geração de escritores começa a emergir e novas revistas aparecem. John Campbell vai dando lugar a novos nomes, como o de Anthony Boucher e Francis McComas, editores da The Magazine of Fantasy and Science Fiction (fundada em 1949), e H. L. Gold, editor da Galaxy Science Fiction (fundada em 1950), que promovem uma visão politicamente mais liberal e literariamente mais exigente.

Pode considerar-se que durante a década de 1950 o género atinge uma maturidade e sofisticação indispensáveis para o seu desenvolvimento posterior. Apadrinhados por Boucher, McComas e Gold, surgem nomes como Philip K. Dick, Damon Knight, Ray Bradbury e Cordwainer Smith, que trazem para a ficção científica novas temáticas e novas formas de abordagem, apesar de continuarem a ser publicadas muitas histórias que mantêm as fórmulas narrativas de sucesso da space opera.

Mais ou menos em simultâneo com o fim da era dourada, começa também o fim do domínio do magazine e assiste-se à migração para outro medium.

A Astounding Science Fiction já havia mudado para o formato digest em 1943 e melhorado a qualidade do papel. Outras revistas seguiram o seu exemplo, abandonando a pulp e aproximando-se do formato livro. O próprio livro enquanto meio de comunicação e transmissão de ideias ganha mais popularidade com a vulgarização da edição de bolso e da capa mole, e a expansão desse mercado vai também contribuir para a contração do mercado dos magazines.

Os baixos custos de publicação em paperback vão fazer com que o livro passe a ser o meio de difusão dominante da ficção científica e que 
as narrativas passem de conto a novela. Muitas das séries publicadas mensalmente nas revistas são coligidas $^{11}$ e publicadas como livro.

Paralelamente, o American News Service, principal distribuidor americano, é declarado monopólio em finais de 1950, o que vem trazer limitações à circulação de revistas, fazendo com que muitas desapareçam do mercado.

As revistas sobreviventes vão dando também lugar a antologias, nomeadamente de ficção científica (a partir de 1949, cria-se a tradição de publicar a antologia das melhores histórias do ano), que vão desempenhar um papel importante no estabelecimento de uma tipologia temática dentro do género e na sua introdução em livrarias e bibliotecas.

À medida que o mercado de livros cresce, algumas editoras vão desempenhar um papel importante na publicação de ficção científica, como é o caso da Doubleday, da Ballantine e da Ace Books, que, de alguma maneira, vão ocupar as funções que anteriormente cabiam aos editores das revistas na seleção, orientação e promoção de trabalhos, adaptando-os às políticas editoriais do novo mercado.

Nos anos de 1960, há uma nova fase de aumento da procura de ficção científica. A geração de escritores e leitores nascida depois da Segunda Guerra começa a chegar ao final da adolescência. Crescera numa época de abundância e de progresso tecnológico, mas debaixo da ameaça nuclear e da tensão da Guerra Fria. É a geração que assiste à luta pelos direitos civis, ao assassinato de John F. Kennedy e à guerra do Vietname. Tem formação universitária, desconfia das instituições e envolve-se ativamente na vida social, protagonizando a revolução cultural da década. É a geração que assume a falência das categorias mentais modernas, que reclama um mundo novo e se considera capaz de o construir, recuperando categorias pré-modernas com a promessa implícita de as superar. De alguma maneira, pode mesmo considerar-se que os mundos científico e tecnológico reais se sentem, por esta altura, como um cenário de ficção científica pré-holocáustico, politicamente opressivo, do qual é necessário escapar. E a ficção científica fornece, uma vez mais, as ferramentas para reinventar o futuro,

${ }^{11}$ A. E. Van Vogt propõe o termo fixup para descrever um livro criado a partir de histórias anteriormente publicadas às quais é adicionado novo material para que possam ser lidas como novela (Clute e Nicholls, 1993:432). 
adaptando-se às necessidades do presente e recuperando elementos do passado. Talvez por isso dois dos livros mais vendidos da década sejam Dune, de Frank Herbert, publicado em 1965, que assenta numa retrovisão, e Stranger in a Strange Land de Robert Heinlein, publicado em 1961, que oferece o encontro entre uma alteridade humanizada e um mundo estranho.

Durante esta década a Astounding Science Fiction, numa procura de novo fôlego, muda o nome para Analog, mas continua a ser incapaz de conquistar a nova geração de leitores que crescem e se fidelizam numa ficção científica em livro.

Enquanto nos Estados Unidos da América a era magazine cedia lugar à era paperback, no Reino Unido uma revista iria conseguir aquilo que décadas de literatura hardback não haviam conseguido, originando uma espécie de fenómeno de migração inverso ao que acontecera no início do século.

Apesar do estatuto e importância de autores como Aldous Huxley, George Orwell e Olaf Stapledon, estes nunca se enquadraram na tradição da ficção científica norte-americana. Eram encarados como fenómenos paralelos, ligados a padrões literários diferentes e com baixo reconhecimento por parte dos fãs. Por isso, no Reino Unido, o centro difusor da ficção científica norte-americana era um núcleo relativamente restrito de magazines editados por E. J. Carnell, nomeadamente a New Worlds, Science Fantasy e Science Fiction Adventures.

Nascida como fanzine, designação atribuída a periódicos publicados por fãs, a revista Nova Terrae passara a designar-se New Worlds e tornara-se magazine especializado em 1949. Durante a década de 1950, a importância da New Worlds resume-se largamente à publicação das histórias de Arthur C. Clarke, o autor britânico de ficção científica mais conhecido e respeitado nos Estados Unidos. Mas na década seguinte é na New Worlds que vão emergir os nomes responsáveis pelo movimento que ficou conhecido como Nova Vaga.

A nova vaga da ficção científica é, tal como o movimento cinematográfico francês do qual recebe o nome, um movimento disruptivo que pretende quebrar as tradições narrativas. É, mais uma vez, impulsionado por um editor, Michael Moorcoock, que em 1964 assume a edição da New Worlds. As vozes mais importantes desta nova vaga são as de Brian Aldiss, John Brunner e J. G. Ballard. Este último escritor já publicava nos Estados 
Unidos em 1964, mas Moorcoock convence-o a voltar ao formato mais experimental do conto e a publicar na New Worlds. Para Ballard, a base temática já não é a biologia mas a psicologia. O espaço desloca-se para o espaço interior (inner space), criando novos caminhos de exploração que vão ser seguidos pelos outros autores.

No entanto, apesar de inovadora em termos temáticos e estilísticos e geograficamente deslocada, a nova vaga não deve ser encarada como uma rutura absoluta com a tradição da ficção científica norte-americana. Ela foi potenciada por todo um movimento de transição que se inicia no pós-guerra e que, por razões sociais, culturais, políticas e geracionais, atinge o clímax em meados da década de 1960. Aliás, como alguns autores sublinham, a expressão new wave acaba por adjetivar tudo o que é diferente ou obscuro, ainda que muitas vezes o vanguardismo seja meramente estilístico e possa servir para mascarar algum vazio de significado.

No final da década de 1960 começa a esboçar-se uma ficção científica comprometida com a defesa de determinadas minorias. Joanna Russ e Ursula K. Le Guin trazem as reflexões sobre o género para o centro da ficção científica. Samuel R. Delany, negro e homossexual, é outro autor que vai surgir nesta altura, contribuindo para aquilo que Roberts (2000:83) classifica como a "erupção da alteridade nas estruturas de produção da própria ficção científica”, e uma nova era começa a nascer.

\section{Star Trek e o audiovisual}

No final da década de 1960 há outro acontecimento decisivo na história da ficção científica: o início da série Star Trek.

Star Trek representa uma nova forma de serialização da ficção científica. De algum modo é um retorno ao magazine, quer no formato de consumo quer no estilo, na combinação de fórmulas narrativas populares, temperadas por uma ideologia liberal adequada ao espírito cultural da década. Com Star Trek, a ficção científica atinge uma popularidade até aí sem precedentes, inaugurando uma nova fase que corresponde a um novo tipo de media: os audiovisuais. 
Sem a mediação da palavra escrita, o consumo da ficção científica simplifica-se. Malmgren $(i d$.) considera que qualquer leitor de ficção científica necessita de desempenhar as tarefas de interpretação e concretização para descodificar um texto literário. A concretização é a construção do paradigma ausente, em que o mundo narrado assenta, que é feita através de uma leitura conjetural que se vai confirmando ou infirmando ao longo da narrativa. Esta tarefa quase científica de inferição, que simultaneamente seduzia e afastava leitores, deixa de ser tão exigente no formato audiovisual. O mundo passa a ser mostrado bidimensionalmente, concretizado, construído. O novum já não é apenas cognitivo, mas também visual, o que facilita a iniciação de novos apreciadores do género.

Por outro lado, em termos temáticos, Star Trek oferece uma diversidade que permite agradar a todas as audiências. A noção de espaço como última fronteira remete para o western cósmico, a viagem numa nave perdida na vastidão do Universo remete para a ficção náutica, dois temas predominantemente masculinos, como é também a exploração da USS Enterprise como veículo, arma de ataque e defesa e dispositivo de contacto e comunicação. Nesta perspetiva, assume-se como gadget science fiction, cativando o público juvenil e os apreciadores de dispositivos tecnológicos, leitores típico da ficção científica das pulp. No entanto, Star Trek tem a particularidade curiosa de cativar uma audiência maioritariamente feminina, mesmo quando a relação romântica mais estável identificada pelos fãs seja entre Kirk e Spock, o que atesta as alterações que decorrem nas próprias estruturas de receção e o potencial do audiovisual para a captação de públicos.

Uma outra forma de ler Star Trek é como série que retrata o encontro com a diferença, não apenas na forma metafórica do alienígena, mas no interior da própria tripulação da USS Enterprise, constituída originalmente pelo capitão James T. Kirk, o primeiro oficial Spock, o oficial médico McCoy, a tenente Uhura, o engenheiro chefe Montgomery Scott, a enfermeira Christine Chapel, o tenente Checkov e o oficial de comunicações Sulu. O desejo expresso por Gene Roddenberry era o de representar um futuro em que não existisse discriminação, daí que a tripulação do Star Trek seja multirracial e tenha uma personagem feminina e afro-americana como oficial de comunicações, a tenente Uhura. O seu caráter revolucionário manifesta-se também 
no facto de ser o primeiro programa televisivo a mostrar um beijo inter-racial, entre Uhura e Kirk, apesar de acontecer enquanto ambos estão sob o controlo de uma entidade alienígena. Poderemos sempre questionar os limites do liberalismo da série, no entanto, o ideal de igualdade subjacente à narrativa é suficiente para captar as franjas de audiência que lutavam pela afirmação da sua diferença, sem afastar espetadores mais conservadores.

A partir de Star Trek, a ficção científica deixa de poder associar-se a um determinado género, idade, raça ou estatuto social e passa a ser um fenómeno de massas. A capacidade de mobilização e organização de fãs, que sempre caracterizou o género, multiplica-se. Foram as cartas dos fãs que permitiram a manutenção da série no ar entre 1966 e 1968, como foram também os trekkers ou trekkies, designação atribuída aos fãs de Star Trek, que se mobilizaram para que o primeiro vaivém espacial recebesse o nome de USS Enterprise.

Sem a mesma popularidade de Star Trek, mas marcando decisivamente a transição da escrita para a imagem, é lançado em 1968 o filme 2001: a Space Odyssey, uma adaptação do romance de Arthur C. Clarke realizada por Stanley Kubrick. O filme é notável em vários aspetos. Por um lado, a viagem espacial pode considerar-se antecipatória do voo e aterragem da Apollo 11 em solo lunar, por outro pode considerar-se o primeiro filme a retratar o medo da tecnologia, num momento em que a informática começa a instituir-se enquanto ferramenta de trabalho. O 2001 é reflexo da consciência de que o avanço da humanidade é indissociável das ferramentas que usa, mas que a vulnerabilidade orgânica do ser humano constituirá uma desvantagem quando comparado com a natureza maquínica do computador. Contudo, o filme encerra com a imagem otimista de uma criança que caminha entre as estrelas, prenunciadora de uma nova fase da evolução da humanidade.

Em termos de ficção científica literária, a década de 1970 parece relativamente desinteressante, sobretudo quando comparada com a promessa de inovação da década anterior e até com os acontecimentos que ocorrem na própria realidade. De acordo com Edward James (1994), as aterragens da Apollo na lua entre 1969 e 1972 habituam o público à textura quase ficcional da realidade, banalizando o conceito de viagem espacial. 
Mais uma vez dialeticamente, realidade e ficção condicionam-se mutuamente, mas as sucessivas transmissões televisivas das aterragens e do drama da Apollo 13, a série Star Trek e o filme 2001: A Space Odyssey, contribuem decisivamente para a transição de um modo predominantemente literário para um modo predominantemente audiovisual, posição que se vai consolidar durante a década de setenta.

\section{Modo Cinematográfico}

Em 1977 é lançado o filme Star Wars, de George Lucas, que faz com que a ficção científica passe de um género menor para um dos modos cinematograficamente dominantes em Hollywood. Lucas consegue traduzir visualmente as narrativas de E. E. Smith, combinando princesas, aventureiros, heróis, imperadores, naves, robôs, num esquema simples e maniqueísta de forças do bem contra o mal, replicando os ingredientes das novelas espaciais dos magazines pulp. Após o sucesso de Star Wars, seguem-se vários filmes que contribuem para consolidar a ficção científica como género cinematográfico e como fenómeno cultural. Nos anos que se seguem são lançados Superman (Richard Donner, 1978), The Black Hole (Gary Nelson, 1979), Alien (Ridley Scott, 1979), Star Trek - The Motion Picture (Wise, 1979), Battle Beyond the Stars (Jimmy Murakami, 1980) e ainda as séries televisivas Battlestar Galactica (1978-80) e Buck Rogers in the 25th Century (1979-81).

Enquanto a ficção científica se populariza na forma cinematográfica, torna-se também tema de reflexão académica: começa a ser lecionada nas universidades, aumentam as publicações sobre ficção científica e surgem revistas académicas especificamente dedicadas a este género narrativo, como a britânica Foundation (1972) e a norte-americanas Science Fiction Studies (1973), que se juntam à precursora Extrapolation, fundada em 1959 por Thomas Clareson. O despertar do interesse académico pela ficção científica inscreve-se numa tendência mais geral de interesse pelos fenómenos de cultura popular, mas deve-se também ao facto de alguns dos escritores da nova geração serem professores universitários ou desenvolverem investigação académica, como é o caso de Samuel Delany, Brian Aldiss e James Gunn. 
No final da década de 1970, existe já um corpo teórico consistente e a ficção científica torna-se um fenómeno respeitado nos meios académicos.

As tendências simultâneas de academização e audiovisualização da ficção científica vão manter-se durante as décadas que se seguem. Durante os primeiros anos da década de oitenta, surgem alguns filmes importantes para sua evolução enquanto género cinematográfico, como Blade Runner (Scott, 1982), The Terminator (Cameron, 1984) e Aliens (Cameron, 1986), que, à imagem do primeiro Alien (Scott, 1979), se direcionam para um público mais adulto, implicando um conjunto de reflexões acerca da identidade e das relações com a alteridade.

Mas, como refere Mark Bould ${ }^{12}$, depois de Star Wars e de E.T. (Spielberg, 1982), a tendência dominante é de uma juvenilização e sentimentalização do cinema de ficção científica, dando como exemplo os filmes Back to the Future (Zemeckis, 1985), Cocoon (Howard, 1985), Explorers (Dante, 1985) e Weird Science (Hughes, 1985), o que, segundo o autor, se deve em larga medida ao contexto político interno dos Estados Unidos.

A partir de meados da década de 1980, o cinema de ficção científica parece ser dominado por um pequeno número de grandes realizadores, como Steven Spielberg (Jurassic Park I, II e III -1993, 1997, 2001, A.I. - Artificial Intelligence, 2001, e Minority Report, 2002), James Cameron, (Aliens, 1986; The Abyss, 1989; The Terminator, 1984, Terminator 2: The Judgement Day, 1991), Paul Verhoeven (Robocop, 1987; Total Recall, 1990; Starship Troopers, 1997; The Hollow Man, 2000), Roland Emmerich (Universal Soldier, 1992; Stargate, 1994; Independence Day, 1996, Godzilla, 1998), John Carpenter (Escape from New York, 1981, The Thing, 1982 e Escape from L. A., 1996).

Um outro fenómeno importante das décadas de oitenta e noventa é a serialização dos filmes de ficção científica. À imagem de Star Wars, também Alien, The Terminator, Back to the Future, Men in Black, Escape from NY, Robocop e The Matrix são serializados, conseguindo assim uma fidelização da audiência, à imagem do que acontecia nos magazines mensais.

A aproximação do final do milénio inspirou um ciclo de filmes pré-apocalípticos ou de catástrofe, alguns na zona de fronteira com a ficção

12 Film and Television, in James e Mendlesohn, 2003:79-95. 
científica, como Outbreak (Petersen, 1995), Twelve Monkeys (Gilliam, 1995), Dante's Peak (Donaldson, 1997), Volcano (Jackson, 1997) The Fifth Element (Bresson, 1997), Armageddon (Bay, 1998) Deep Impact (Mimi Leder, 1998). Mas um dos fenómenos mais marcantes da década de noventa é a crescente permeabilidade entre os vários media audiovisuais, numa estratégia comercial alargada. O cinema adapta séries televisivas, como acontece com My Favourite Martian, adaptado por Petrie em 1999, inspira séries televisivas (Stargate - SG1, desde 1997), faz remakes de filmes antigos (The Nutty Professor, Shadyac, 1996), fornece material temático e personagens aos jogos de vídeo (o jogo Space Invaders é uma adaptação das batalhas espaciais de Star Wars), e aproveita o sucesso das personagens dos videojogos para as passar ao grande ecrã (SuperMario, Jankel e Morton, 1993, Lara Croft, West, 2001), num jogo de relações com benefícios mútuos. A própria relação entre a escrita e o cinema começa a funcionar no sentido inverso, originando os spin-offs, textos que serviram de argumento a filmes e séries e que são posteriormente comercializados como material promocional, juntamente com brinquedos, canecas, camisolas e outros produtos.

Graças a este fenómeno, a ficção científica ganha durante as últimas décadas uma popularidade inequívoca, resultante em larga medida dos processos de globalização e fragmentação que alimentam a crescente mercantilização do mundo. A ficção científica traduz a incerteza que se vive no mundo empírico. A geração que na década de sessenta desejava mudar o mundo, instala-se no sistema que queria abolir. A utopia tecnológica do sonho americano, que a ficção científica alimentara, falhara. A própria ficção científica deixa de ter uma memória viva. Todos os grandes nomes que a tinham moldado ao longo de décadas estavam mortos, tornando-se assim mais dependente do presente do mundo do que do seu passado.

Além disso, a partir dos anos de 1980, há a dupla sensação de que a realidade ultrapassou a ficção científica e de que a realidade ficou aquém da ficção científica. Os futuros reduzem-se, os espaços aproximam-se e as perceções distorcem-se. Como John Clute (2003) argumenta, a visão ficcional torna-se indistinta do mundo que tenta diferenciar. O futuro chegara no dobrar do milénio, e todas as promessas implícitas no discurso da ficção científica da era dourada pareciam por cumprir. Paralelamente, a ficção 
científica falhara em antecipar o conjunto de transformações que ocorria no mundo real. Daí que, segundo Clute $(i d$.), as narrativas das últimas duas décadas tenham sido uma espécie de despedida relutante em relação a um futuro em que o próprio género nos ensinou a acreditar, mas que perdera o significado com o advento do século XXI.

Mas os contextos de mudança e incerteza são também propícios ao crescimento das narrativas em que essa incerteza e mudança se podem projetar. O clima de desilusão e pessimismo não representou um esgotamento do género. Apesar de se ter assistido a algum abrandamento literário, a ficção científica tornou-se um dos géneros cinematográficos dominantes, adaptando velhas fórmulas aos novos contextos, fornecendo visões inquietantes e moldando expectativas em relação ao mundo que há-de vir. Porque a ficção científica é isso mesmo, um género que se reinventa inventando o futuro, num movimento de adaptação ao presente. 
(Página deixada propositadamente em branco) 


\section{TIPOLOGIAS DA FICÇÃO CIENTÍFICA}

\section{Sub-Géneros e Categorias}

Resultante de múltiplas tradições e contradições, moldada por diferentes espíritos e expressa em diversos media, a ficção científica apresenta uma grande diversidade de temas ou, se preferirmos, de subgéneros. Alguns desses subgéneros estão intimamente ligados a determinados momentos da sua evolução e deram origem a designações que são usadas muitas vezes como forma de adjetivação. Exemplos são a já referida space opera, sinónimo de ficção científica de aventuras, que adjetiva e caracteriza a ficção científica resultante ou herdeira da tradição Gernsback, centrada na ação e orientada para a satisfação das necessidades sublimativas. Também típica da era Gernsback é a gadget science fiction, que centra a narrativa quase exclusivamente num dispositivo tecnológico, o que pode conduzir a outras formas de classificação.

Uma das distinções mais frequentes é entre ficção científica hard e soft, em que hard é o conceito definidor e soft o conceito opositor. De facto, é apenas a partir do momento em que ficção científica inflete na direção das ciências sociais e humanas, durante a década de 1950, que surge a necessidade de fazer a diferenciação em relação à ficção científica anterior. No entanto, os limites deste subgénero acabam por escapar a qualquer tentativa de circunscrição. Em termos temáticos, uma narrativa pode ser classificada como hard desde que esteja ligada às ciências físicas, mas, como sublinha Kathryn Cramer $^{13}$, essa ligação pode ser de aceitação, oposição

13 Hard science Fiction, in James e Mendlesohn, 2003:186-208. 
ou diálogo. Além disso, independentemente de se constituir como fonte direta do novum da narrativa, a ciência é normalmente traduzida numa linguagem que lhe permite ser usada como uma espécie de mitologia ou iconografia, que faz com que a maior parte da ficção científica se possa classificar como hard.

Apesar de estar intimamente associado às vozes masculinas e tecnologicamente otimistas das eras de Gernsback e Campbell, o conceito também escapa a uma circunscrição temporal, uma vez que a corrente cyberpunk dos anos 1980, embora mais pessimista no tom, recupera alguns dos traços distintivos da hard $s f$.

Uma outra variante popular da ficção científica, objeto de classificação corrente, é a science fantasy que, como foi analisado, se caracteriza pela introdução de um elemento sobrenatural num mundo projetado sobre o horizonte da episteme científica.

Mas limitar a ficção científica aos subgéneros para os quais existe uma designação mais ou menos consensual, mais ou menos popular, constitui uma forma de classificação pobre e redutora. De facto, ao longo de mais de um século de existência, ela tem alargado o seu campo temático, retomando e reinventando alguns dos temas da tradição literária que lhe é subjacente ou adjacente, dividindo-se, multiplicando-se e metamorfoseando-se em múltiplos subtipos narrativos.

Uma tentativa de classificação mais abrangente poderá incluir temas ou ícones tão diversos como naves, computadores, realidade e inteligência artificiais, dispositivos tecnológicos, avanços científicos, seres alienígenas, monstros, super-heróis, robôs, androides, manipulação e mutação genética, viagens no tempo, linhas históricas desviantes, futuros apocalípticos, utopias e distopias. Estes temas podem aparecer isoladamente, ou agrupar-se com outros em torno de um conceito ou categoria que lhes confira unidade.

\section{Espaço, Tempo, Máquina e Monstro}

Mark Rose (1981) considera que o paradigma da ficção científica é o encontro entre o humano e o não humano e que esta relação se projeta 
em quatro categorias distintas: espaço, tempo, máquina e monstro, originando quatro tipos específicos de narrativa.

$\mathrm{Na}$ categoria espaço, o encontro com o não humano e não terrestre dá origem a histórias de encontro com o alien e de viagens extraordinárias, interplanetárias ou intergalácticas. No entanto, as narrativas da categoria espacial representam a versão mais básica da ficção científica, em que as preocupações com a diferença se situam sobretudo ao nível da natureza física e as criaturas extraterrestres são entendidas como uma versão animada da natureza que as origina.

A categoria tempo inclui todo o tipo de narrativas situadas no futuro ou numa versão alternativa do presente, refletindo sobre as transformações resultantes da passagem do tempo. São narrativas centradas sobre o significado da história e os seus efeitos, assumindo como possíveis ou prováveis um conjunto de continuidades e descontinuidades em relação ao presente empírico.

$\mathrm{Na}$ categoria máquina, a humanidade é tomada como criadora e, frequentemente, vítima do não humano. Histórias em que robôs, computadores e máquinas inteligentes desempenham um papel central entram nesta terceira categoria. Rose inclui ainda neste grupo as máquinas sociais das distopias.

$\mathrm{Na}$ categoria monstro, o elemento inumano pode estar localizado fora ou dentro da própria humanidade. As narrativas desta categoria dependem normalmente de uma transformação que pode ocorrer de um dos seguintes modos: o encontro com o alienígena pode conduzir a variações ou mutações que transformam o humano em monstro; o tempo pode conduzir a mudanças na humanidade por evolução, ou o próprio homem pode ser simultaneamente agente e sujeito dessa metamorfose, como acontece em histórias de apocalipse pós atómico. A monstruosidade pode ser negativa ou positiva, enquadrando-se neste último grupo as narrativas de super-heróis.

Com esta grelha de classificação, Rose reduz toda a variedade de enredos, fórmulas e contextos da ficção científica às quatro instâncias de encontro entre o humano e o não humano, sublinhando que a maior parte dos textos pode inscrever-se ou ser lida a partir de múltiplas categorias. 


\section{Atuantes e topoi}

Carl Malmgren (1991) apresenta uma outra grelha classificativa das narrativas da ficção científica. De acordo com este autor, a infinita multiplicidade de elementos pode resumir-se a atuantes (actants), conceito que resume todas as formas possíveis de alteridade, e topoi, onde se podem inscrever todos os contextos espaciais e temporais, físicos, sociais e topográficos.

Em qualquer das duas classes pode ser introduzido um novum e, apesar de uma narrativa poder apresentar atuantes e topoi, Malmgren considera que um deles é sempre dominante e, por isso, confere identidade tipológica ao texto.

No grupo atuantes, Malmgren não considera a diferença entre alienígenas e máquinas, e propõe uma classificação em não humanos, super-humanos e sub-humanos, num espetro que vai do computador inteligente ao monstro extraterrestre. O paradigma das narrativas desta categoria é o encontro com o outro, que conduz necessariamente à reflexão sobre os limites da humanidade, daquilo que no outro remete para o eu.

A categoria topoi inclui as narrativas em que o novum é essencialmente social, como acontece na utopia ou distopia, em que o leitor é convidado a fazer comparações com a organização social em que está inserido, obrigando a refletir sobre a relação entre o indivíduo e a sociedade, num sentido lato que envolve a produção de conhecimento e a tecnologia. Inscrevem-se também nesta categoria as narrativas que resultam da mera invenção ou apropriação de um dispositivo ou aparelho tecnológico, explorando a relação do ser humano com a tecnologia, e as de mundos ou futuros possíveis, que obrigam a refletir sobre a relação da humanidade com o contexto físico e sobre a forma como este modela e condiciona as diversas formas de vida.

Partindo da divisão em atuantes e topoi, Malmgren propõe quatro tipos de narrativa aos quais toda a ficção científica se pode reduzir: encontro com alienígenas (alien encounter), sociedade alternativa (alternate society), história de dispositivo tecnológico (gadget story) e mundo alternativo (alternate world).

Apesar das diferenças entre as propostas de Rose e Malmgren, pode fazer-se coincidir o encontro com alienígenas com a categoria monstro, a 
história de dispositivo tecnológico com a máquina e a sociedade e mundo alternativos com o tempo e o espaço. Ao fazê-lo, o traço mais distintivo entre Rose e Malmgren passa a ser a defesa da permeabilidade ou impermeabilidade entre categorias e narrativas, possibilitando ou impedindo classificações múltiplas, uma vez que Malmgren considera que o novum dominante determina a classificação estanque de cada texto.

\section{Ícones}

Gwyneth Jones (2003) propõe uma outra forma de classificação das narrativas de ficção científica, assente na iconografia específica do género. Para esta autora, existe um reportório central de ícones que permitem anunciar e distinguir a ficção científica de qualquer outro género narrativo.

Vai considerar quatro conjuntos de ícones, a partir dos quais deriva formas narrativas específicas. Num primeiro grupo reúne foguetões, naves, habitats espaciais e ambientes virtuais. Para Jones, o foguetão, com a sua forma fálica apontada ao céu, é um símbolo incontornável de poder e conquista e por isso vai dominar o imaginário da ficção científica durante os anos trinta do século passado. Mas, pela sua forma, acaba por ficar associado às armas alemãs V2 e, ao longo da década seguinte, vai dando lugar à nave espacial como veículo de transporte interplanetário ou como microcosmos, um mundo autocontido onde se reproduzem as relações humanas do mundo empírico e se produzem encontros com as várias formas possíveis de alteridade. A nave constitui-se como um espaço familiar à deriva num Universo estranho e muita da ficção científica audiovisual explorou as suas potencialidades narrativas, podendo a nave Enterprise da série Star Trek ser apontada como exemplo.

Uma segunda categoria de ícones inclui robôs, androides, cyborgs e aliens, abrangendo as várias possibilidades de alteridade que podem ir do robô sub-humano até ao clone pós-humano.

O terceiro tipo de imagens é constituído por aquilo que Jones designa como mundos imaginados, embora sublinhe que estes cenários derivam, em larga medida, da diversidade ecológica do planeta Terra. 
Finalmente, numa quarta categoria, que designa genericamente por cientistas loucos e damas em perigo, agrupa o leque de personagens típicas, carateres planos a que o género frequentemente recorre. Esta categoria é menos autónoma que as anteriores, uma vez que estes ícones raramente dominam a narrativa, aparecendo como uma espécie de personagens secundárias ou até figurantes, cuja importância deriva apenas da sua relação com os outros elementos.

Pode concluir-se que, em última análise, também a dimensão visual e iconográfica da ficção científica remete para as noções de máquina, monstro e tempos e espaços alternativos, não havendo, por isso, uma diferença muito significativa em relação à categorização temática proposta pelos autores anteriores.

\section{Alteridade, Tecnologia, Tempo e Espaço}

Alteridade, tecnologia ${ }^{14}$, tempo e espaço são, de facto, os conceitos nucleares em torno dos quais toda a ficção científica gravita. Se pretendermos ir mais longe, podemos mesmo argumentar que todos eles se podem sintetizar no de alteridade, uma vez que a ficção científica trata sempre do encontro com o outro (humano, alienígena ou máquina), mediado pela tecnologia, que acontece num espaço e tempo deslocados, ou seja, num mundo outro que pode ser ficcionalmente especulado ou extrapolado a partir do mundo empírico. A diversidade de narrativas resulta das várias combinações entre os quatro conceitos e do grau de otimismo com que são apresentados.

Tempo e espaço outros significam um mundo outro, o que remete para a noção clássica de utopia. Em rigor, o modo temporal da ficção científica não é a utopia ${ }^{15}$, mas a outopia, um lugar outro situado em lugar nenhum.

${ }^{14}$ Do mesmo modo que anteriormente foi argumentado que a expressão ficção científica negligenciava a dimensão tecnológica, a escolha do conceito tecnologia é igualmente redutora, uma vez que muita da ficção científica atual reflete sobre as possíveis consequências dos desenvolvimentos da ciência.

15 Utopia é o termo criado por Thomas More que resulta da fusão das palavras gregas eutopia (lugar feliz) e outopia (lugar nenhum). Assim, o significado etimológico de utopia é lugar feliz em lugar nenhum. 
O mesmo se pode aplicar ao tempo. As narrativas da ficção científica decorrem num tempo outro, muitas vezes em aderência ao passado e futuro que a linha temporal impõe, mas que é tempo nenhum, um passado, presente ou futuro que não existe fora do imaginário de quem o cria e de quem o recria através da leitura.

Visões positivas relativamente ao tempo e espaço dão origem a narrativas otimistas que se podem classificar como eutópicas e eucrónicas retratando espaços e tempos mais perfeitos que o mundo empírico.

A relação positiva entre o tempo e a tecnologia dá origem a eucronias tecnofílicas que estão essencialmente associadas à fase inicial do desenvolvimento do género. Não apresentam sociedades perfeitas e estáticas como as utopias literárias clássicas, mas antes a promessa de um movimento progressivo perpétuo através da tecnologia e da ciência, que conduzirá a um futuro melhor, aquilo a que alguns autores chamam utopismo tecnológico.

Quando as narrativas se centram num futuro otimista em que a tecnologia é positiva, a alteridade normalmente não desempenha um papel central. $\mathrm{Na}$ maior parte dos casos é representada pelo próprio humano, deslocado num futuro em que a capacidade tecnológica lhe permite conquistar as fronteiras do espaço, o que propicia uma diversidade de encontros com outras formas de alteridade que podem ser positivas (divinizadas) ou negativas (demonizadas), mas que, em qualquer dos casos, continuam a ser largamente uma projeção das características humanas. As narrativas de aventura no espaço poderão incluir-se neste grupo.

As (e)utopias da ficção científica aderem ao modelo clássico fornecido por Thomas More, retratando civilizações em que a tecnologia ou a sua ausência permitem uma organização social mais perfeita do que a do mundo real. O outro é normalmente apresentado de uma forma positiva e a diferença em relação aos humanos pode ser mais radical do que nas narrativas predominantemente de tempo. As utopias tendem a ser pedagógicas, mostrando aquilo que a humanidade poderia ser.

Quando estão associadas a uma visão negativa da tecnologia, as utopias apresentadas são tecnofóbicas e os mundos aproximam-se do modelo das sociedades recoletoras primitivas, em que a coexistência é pacífica e a relação com a natureza harmoniosa. Quando estão associadas a uma visão 
positiva da tecnologia, os mundos apresentados resultam por norma do avanço científico-tecnológico, cujas consequências se refletem numa organização social, cultural e política mais justa.

James (2003) argumenta que a capacidade de imaginar um mundo melhor morreu durante o século xx com o horror das guerras globais, do genocídio e do totalitarismo, daí que o modo dominante de retratar o tempo e o espaço na ficção científica recente seja negativamente, originando distopias e discronias.

As discronias são presentes ou passados alternativos e futuros próximos ou distantes em que a realidade apresentada é pior do que a do presente real. As discronias são frequentemente narrativas apocalípticas ou pós-apocalípticas, estando por vezes associadas a uma visão negativa da tecnologia, com reflexos em termos de organização social e política. Nestes casos, as transformações que ocorrem no espaço de tempo que medeia entre a realidade presente e a sociedade discrónica refletem as consequências de um desenvolvimento científico e tecnológico que conduz ao esgotamento dos recursos, à guerra global, à escravização da humanidade pelas máquinas ou outras formas de vida, a desordens naturais e, consequentemente, à degradação da vida humana.

Quando as transformações que provocam a discronia têm causas naturais, a ciência e a tecnologia podem aparecer numa forma positiva, como a atividade criadora que permite salvar a humanidade. Mas os casos em que a discronia acaba num restabelecimento da ordem a classificação é mais difícil, uma vez que a discronia funciona como pretexto para transmitir uma mensagem positiva, de fé na tecnologia, no engenho do herói ou numa transcendência alienígena salvadora.

Nas discronias, a alteridade pode aparecer sob diversas formas. Pode mesmo ser a entidade negativa que provoca as transformações indesejáveis na humanidade e no curso da história, pode ser uma entidade alienígena salvadora, pode ser a própria humanidade resultante dos processos de evolução e mutação (positiva ou negativamente), outras espécies animais ou os produtos da evolução tecnológica (máquinas que igualam e superam os criadores).

Tratando-se do espaço, uma visão negativa conduz a distopias, lugares outros piores que os conhecidos. Podem ser planetas ou galáxias habitados 
por alienígenas com características e formas de organização menos justas do que as humanas, podem ser ambientes construídos pelos humanos (naves, planetas terraformados, colónias espaciais), ou pode ser a própria Terra num passado ou presente alternativos ou num futuro mais ou menos distante, coincidindo neste caso com a discronia.

Tempo e espaços piores do que a realidade empírica estão frequentemente associados a visões tecnofóbicas, em que a tecnologia é utilizada como instrumento de ameaça, perigo ou morte, ou a tecnologia se institui ela própria enquanto entidade ameaçadora.

As narrativas que projetam uma alteridade tecnológica (computadores, robôs, ciborgues, androides) num futuro sombrio são aquelas em que a tecnofobia é mais acentuada, sendo recorrentes em termos cinematográficos. No entanto, o medo da máquina nem sempre é genuíno ou absoluto. Seres e máquinas tecnologicamente avançados são normalmente combatidos recorrendo a tecnologia anterior, o que acaba, muitas vezes, por reduzir a questão central a um maniqueísmo moral e sublinhar o medo em relação ao progresso e não à própria tecnologia.

Nenhuma das categorias propostas é estanque e qualquer narrativa admite múltiplas classificações. Aliás, qualquer classificação temporal obriga a uma classificação espacial. A distinção entre tempo e espaço serve essencialmente para sublinhar o modo temporal da ficção científica. Um tempo outro reflete-se sempre na configuração do espaço (num espaço outro). O contrário, apesar de frequente, não é necessariamente verdadeiro. Mas, ao distanciar-se do presente, é exatamente dele que a ficção científica trata. Subjacente à alteridade e diferença está a noção de mesmidade. O encontro com o outro serve apenas para refletir sobre o mesmo, o encontro com o futuro para refletir sobre o presente. Outros mundos e outros tempos são sempre projeções desfocadas deste mundo e deste tempo, do real empírico sobre o qual assentam todas as possibilidades. E é à luz do presente de que nasce que a ficção científica pode ser interpretada, num movimento de reflexão sobre as hipóteses que encerra. 
(Página deixada propositadamente em branco) 


\section{CINEMA DE FICÇÃO CIENTÍFICA}

\section{Cinema e ficção científica}

Cinema e ficção científica partilham um conjunto alargado de características. Tal como a ficção científica, o cinema é um produto de fronteira, que resulta do impulso tecnológico de finais do século XIX e que responde às necessidades de sublimação da sociedade industrial moderna e, tal como ela, move-se entre múltiplas categorias, como o realismo e a ficção, a arte e a técnica, o entretenimento e a cultura, a perceção e a inteleção, gerando diferentes teorias sobre os modos como se constrói, se difunde e se recebe.

Como refere Barry Keith Grant ${ }^{16}$, o cinema é, ele próprio, simultaneamente ciência e ficção. É um aparelho tecnológico de gravação e um instrumento de narração ficcional. Permite contar histórias através de imagens captadas e registadas por um dispositivo tecnológico. Os três aspetos centrais a partir dos quais o cinema se constitui são o tempo, o espaço e a máquina, categorias centrais também na ficção científica.

À semelhança do que acontece na ficção científica, o aparente realismo cinematográfico não fornece o que o mundo é, mas o que ele poderia ser. Ocupa um lugar de fronteira entre o realismo e a ficção. No cinema ficcional, o tempo da diegese, retratado no ecrã, constitui sempre um tempo outro, eternamente presente e continuamente tornado presente, o que o coloca num horizonte omnitemporal. Também a ficção

16 Sensuous Elaboration: Reason and the Visible in the Science-Fiction Film, in Kuhn, 1999:21. 
científica se desloca nesta linha de todos os tempos possíveis, estando-lhe apenas vedado o passado que efetivamente foi e o presente que efetivamente é.

Por oferecer mundos que poderiam ser, possibilidades de existência alternativa, o cinema permite satisfação de necessidades que o mundo real nem sempre pode proporcionar, compensações para o espetador, de ordem afetiva, psicológica, ideológica ou social, que se concretizam em possibilidades de identificação, de satisfação de desejos vouyeurísticos e necessidades catárticas e até de legitimação ou crítica do status quo. Também a ficção científica, escapando aos limites do enquadramento espácio-temporal presente e jogando com as expectativas sobre o real possível, permite ao espetador satisfações de ordem psicológica e ideológica e uma aprendizagem sobre futuros possíveis. Qualquer um dos dois fenómenos permite, isoladamente, a satisfação da necessidade de ultrapassar os limites do real. Quando conjugados, multiplicam esse potencial escapista, o que poderá servir de justificação para o sucesso do cinema de ficção científica.

Efetivamente, é na forma cinematográfica que a ficção científica se afirma de modo global, alcançando audiências que não conseguira cativar através de outros meios e formas de difusão. O cinema é o medium que transforma a ficção científica num fenómeno cultural global e de massas. Isto pode justificar-se pelo potencial difusor do cinema e pelas suas políticas de distribuição, mas também pela especificidade da linguagem cinematográfica, que facilita ao recetor a tarefa de construir imaginativamente os tempos, mundos e alteridades da ficção científica. A tarefa nem sempre fácil de imaginar a estranheza, de construir o paradigma ausente, mantinha afastados do género alguns potenciais apreciadores. Com a passagem para um meio de comunicação audiovisual, o leitor deixa de ter de preencher os vazios, de construir sobre o texto, e passa a ter uma narrativa visualmente construída. Ao oferecer uma perceção imediata do extraordinário, a popularidade da ficção científica cresce e torna-se um dos géneros cinematográficos de maior sucesso, num processo de influência mútua que começa na década de 1970 e se deve a um conjunto alargado de fatores. 


\section{Tendências gerais do cinema recente}

A geração de jovens criadores que chega ao cinema na década de 1970 é a primeira com formação universitária específica e a crescer sob a influência da televisão e do espírito liberal da década anterior. Steven Spielberg, George Lucas, Francis Ford Coppola, Brian De Palma, Peter Bogdanovich ou Michael Cimino são exemplos dessa geração, conhecida como movie brats, em que há uma manifesta consciência da história e linguagem do cinema. Perante a aceitação do público, os estúdios acabam por financiar estes novos autores, conseguindo quase sempre bons resultados de bilheteira, como acontece com $M^{*} A^{*} S^{*} H$, de Robert Altman (1970), Chinatown de Roman Polanski (1974), Taxi Driver (Martin Scorsese, 1976), The Godfather (Francis Ford Coppola, 1972), The Godfather: Part II (Francis Ford Coppola, 1974) e Apocalypse Now (Francis Ford Coppola, 1979).

Essencial para esta nova fase do cinema foi o sucesso de Jaws (1975), realizado por Steven Spielberg, que consegue receitas superiores a cem mil dólares, dando origem à atual noção de blockbuster, um produto desenhado para conquistar o mercado. Para Cook e Bernink (1999), Jaws marca o início de um segundo momento na história de Hollywood, em que se reinstaura a produção de filmes com objetivos essencialmente económicos, agora concebidos como matriz de um conjunto diversificado de produtos que inclui cassetes de vídeo, álbuns de bandas sonoras, novelas, comics e jogos. Dois anos depois de Jaws é lançado Star Wars, um sucesso comercial ainda maior, que marca definitivamente a entrada neste novo momento da história do cinema.

A década de 1970 é também marcada por conjunto de inovações tecnológicas, como a televisão por cabo e o videogravador, que se irão massificar ao longo dos anos de 1980 e criar novas exigências à produção cinematográfica. O consumo doméstico de cinema através das videocassetes contribui para uma simplificação dos argumentos e aumento da espetacularidade das imagens, de modo a agradar a todas as audiências. Os efeitos especiais aperfeiçoaram-se ao longo dos anos de 1980, principalmente ao serviço da ficção ou da fantasia científicas, originando grandes sucessos comerciais de que são exemplo The Empire Strikes Back (1980), 
Return of the Jedi (1983), The Terminator (1984) e Robocop (Paul Verhoeven, 1986), mas também em filmes de ação como Lethal Weapon 2 (Richard Donner, 1989) ou $F / X$ (Robert Mandel, 1986), este último centrado na própria criação de efeitos especiais.

A aposta no cinema enquanto medium percetivo, enquanto espetáculo e máquina de sonhos, está patente na filmografia de dois movie brats: Steven Spielberg e George Lucas, que se tornam os realizadores de maior sucesso comercial da sua geração. Ambos perceberam que para retirar o público do conforto do sofá e fazê-lo ir ao cinema era necessário oferecer um conjunto de perceções e emoções que o grande ecrã potenciaria. Os filmes são concebidos e montados de modo a manter o espetador atento ao que poderá acontecer no momento seguinte, como acontece nos três filmes da saga Indiana Jones (1981, 1984, 1988), que combinam simplificação dos enredos com aumento da espetacularidade.

Em termos temáticos, pode assumir-se que na década de 1980 se assiste a uma juvenilização do cinema, notória nos vários géneros. A comédia juvenil surge nessa década com Porky's (Bob Clark, 1982), cujo sucesso origina as sequelas Porky's II: The Next Day (Bob Clark, 1983) e Porky's 3: Revenge (James Komack, 1985). Na ficção científica, E.T. (Spielberg, 1982) e a trilogia Back to the Future (Robert Zemeckis, 1985, 1989, 1990) manifestam a mesma tendência de aposta numa audiência predominantemente juvenil. Mas também o terror se especializa num público jovem e se afirma como um género de sucesso, atestado pelas múltiplas sequelas de Halloween (John Carpenter, 1978), A Nightmare on Elm Street (Wes Craven, 1984) e Friday the 13th (Sean S. Cunningham, 1980). O êxito dos filmes de aventuras, de que são exemplo os filmes Indiana Jones, Lethal Weapon (1987, 1989, 1992, 1998) ou Die Hard (1988, 1990, 1995 e 2007), reforça a aposta em narrativas de ação, simples e fáceis de perceber por qualquer tipo de audiência, que se manterá pelas décadas seguintes.

Os filmes mencionados são ilustrativos de uma outra tendência: a serialização. A estratégia de reutilização de heróis e fórmulas já testadas pelas audiências reduz os riscos comerciais e o investimento em publicidade. O terror, a ação, a ficção científica e a comédia são géneros em que a sequela é comum. 
Mas também há pessimismo no cinema da década de 1980, não só na imaginação distópica da ficção científica mas noutros géneros cinematográficos. Sublinha-se a suspeita de que existem mais níveis de realidade (física, política, psicológica) para além daqueles que são dados a conhecer. Filmes como Blue Velvet (David Lynch, 1985), After Hours (Martin Scorsese, 1985) ou Nikita (Luc Bresson, 1989) exploram as fronteiras existenciais e cognitivas, questionando os limites da perceção.

A ficção científica, rejuvenescida e dignificada em termos cinematográficos pelos filmes da década anterior, mostra-se capaz de traduzir esta incerteza existencial e atinge a sua afirmação ao longo dos anos de 1980, criando novos heróis e futuros possíveis, em filmes como Blade Runner, Total Recall, The Terminator ou Alien.

O domínio da ficção científica enquanto género e a serialização de filmes com sucesso comercial são tendências visíveis ao longo de toda a década de 1990, estendendo-se pelo início do século xxi. Aprofunda-se a suspeita cognitiva e epistemológica e o desencanto existencial da década anterior, propondo-se visões distópicas para futuros cada vez mais próximos, que dão forma às ansiedades sociais, políticas, científicas e tecnológicas que a realidade desperta.

Nos outros géneros cinematográficos, mais ancorados aos limites do tempo e do espaço, a suspeição de que existem dimensões para além da superfície visível, dá origem a novos modelos narrativos que traduzem a fragmentação do próprio real e o relativismo cognitivo e existencial, adotando uma estrutura polifónica, feita de múltiplas linhas narrativas que se entrecruzam numa espécie de mosaico. Encontramo-los em filmes como Short Cuts (Robert Altman, 1993), Pulp Fiction (Quentin Tarantino, 1994) e Magnolia (Paul Thomas Anderson, 1999), em que narrativas não lineares jogam com o espaço e tempo psicológicos, obrigando o espetador a orientar-se numa espécie de labirinto narrativo, de que é exemplar o filme Memento (Christopher Nolan, 2000).

A tendência para a juvenilização do cinema mantém-se nas últimas duas décadas, dando origem a séries de filmes de terror para jovens como Scream (Wes Craven, 1996), Final Destination (James Wong, 2000) ou Jeepers Creepers (Victor Salva, 2001), de comédia juvenil como American Pie (Paul 
Weitz, 1999) e, num jogo de intertextualidade e cruzamento de géneros, de paródia ao terror, subgénero criado para uma audiência capaz de descodificar as convenções narrativas cinematográficas, como acontece com Scary Movie (Keenen Ivory Wayans, 2000), todos eles originando várias sequelas que repetem a fórmula narrativa inicial. O cinema torna-se cada vez mais autorreferencial, resultado de uma maior consciência da sua própria história, de que são exemplo The Untouchables (De Palma, 1987), que recria a queda do carro de bebé pela escadaria de O Couraçado Potenkine (Eisenstein, 1925), ou Pulp Fiction (Tarantino, 1992), em que John Travolta, no papel de Vincent Vega, interpreta uma cena de dança com Uma Thurman, aludindo ao seu desempenho em Saturday Night Fever (John Badham, 1977). Estas referências assumem a literacia cinematográfica do espetador e implicam a noção de que o cinema faz parte de uma cultura ocidental partilhada, inteligível para qualquer audiência do mundo globalizado.

Os últimos vinte anos são também marcados por uma infantilização do cinema, com filmes de animação a conseguirem resultados de bilheteira nunca alcançados por este género, como Beauty and the Beast (Gary Trousdale e Kirk Wise, 1991), Lion King (Roger Allers e Rob Minkoff, 1994), Pocabontas (Mike Gabriel e Eric Goldberg, 1995), Hercules (Ron Clements e John Musker, 1997) ou Mulan (Tony Bancroft e Barry Cook, 1998), todos da Walt Disney Feature Animation. O desenvolvimento da tecnologia de imagens geradas por computador permite dar forma a fantasias cada vez mais elaboradas, como acontece em Toy Story (John Lasseter, 1995), o primeiro filme de longa-metragem inteiramente gerado por computador, ou Shrek (Andrew Adamson e Vicky Jenson, 2001), onde mais uma vez se podem encontrar múltiplas intertextualidades e um desafio às convenções do cinema e da narrativa tradicional. Dirigidos a uma audiência constituída por crianças e adultos, a Pixar Animation Studios (que em 2006 se funde com a Walt Disney Pictures) produz filmes como Monsters Inc. (Pete Docter e David Silverman, 2001) e Finding Nemo (Andrew Stanton e Lee Unkrich, 2003), em concorrência com a Dreamworks, de George Lucas, que, além de Shrek, é responsável por êxitos como Shark Tale (Bibo Bergeron e Vicky Jenson, 2004), Madagascar (Eric Darnell e Tom McGrath, 2005) e Bee Movie (Steve Hickner e Simon J. Smith, 2007). 
Apesar da crescente concorrência de outros media, como a televisão e a internet, o cinema continuou a conquistar audiências ao longo das décadas recentes. Nos últimos anos a tecnologia torna o cinema mais acessível e os filmes facilmente revisitáveis. O próprio cinema, enquanto meio de comunicação e difusão, sofre alterações ao nível da produção e do consumo durante os últimos trinta anos, adaptando-se a novas realidades mediáticas e às necessidades do público. Recriou espaços, estratégias e tecnologias de modo a responder aos desafios que se foram colocando. Ir ao cinema é, atualmente, uma prática associada a outras formas de consumo. As salas de cinema estão situadas em centros comerciais e a produção de filmes aposta na oferta de experiências sensoriais intensas, adaptando e assimilando narrativas anteriores e experiências marginais, diversificando a oferta e proporcionando aos espetadores mundos e visões alternativas às que a realidade empírica lhes proporciona. Se, por um lado, se pode considerar que as últimas décadas promovem uma superficialização do conhecimento, focando a dimensão percetual em detrimento da inteleção, também é verdade que a exigência dos espetadores em relação aos filmes cresce e que a audiência tem uma literacia cinematográfica elevada, que lhe permite descodificar, interpretar e atribuir sentidos a narrativas cada vez mais afastadas da realidade empírica e dos padrões narrativos convencionais.

Estas tendências gerais encontram-se também na própria ficção científica, género que desempenha um papel essencial no desenvolvimento das capacidades narrativas do próprio cinema. A relação entre a ficção científica e o cinema é simbiótica. Se o cinema fez crescer o número de admiradores de ficção científica, esta contribui também para o crescimento do cinema. Foi, em grande parte, a necessidade de transpor para imagem mundos e seres cada vez mais estranhos que comandou os desenvolvimentos tecnológicos da linguagem cinematográfica, tornando-a capaz de dar forma imagética a universos extraordinários. A deslocação temporal e espacial a que a ficção científica obriga também contribui para que esteja um passo à frente dos outros géneros. A visão alternativa que propõe torna-a dependente dos efeitos especiais. Os seus filmes, mais do que em qualquer outro género, refletem a tecnologia que os torna possíveis. Muitas vezes essa tecnologia torna-se tão central para a narrativa como o seu próprio enredo. Um dos casos mais 
ilustrativos é o filme Jurassic Park (Steven Spielberg, 1993), em que o novum é a capacidade de clonar dinossauros a partir do ADN extraído de insetos fossilizados, que obriga o cinema a responder ao desafio de criar imagens verosímeis de dinossauros em interação com humanos. A capacidade de produzir imagens digitais, inteiramente geradas por computador, de animais desaparecidos há milhares de anos, parecia, em 1993, tão futurista como a possibilidade de os clonar. Um outro exemplo é Avatar (Cameron, 2009), considerado um dos filmes mais caros da história do cinema pela tecnologia inovadora, capaz de dar ao espetador uma experiência tridimensional próxima da realidade e conferir realismo ao exótico habitat e habitantes de Pandora.

Assistir a um filme de ficção científica é assistir também ao modo como a tecnologia cinematográfica permite mostrar, de forma sensorialmente cada vez mais complexa, uma realidade que não existe e que, no caso das imagens geradas por computador, nem sequer é um ícone, porque não remete para nenhum referente mas para um algoritmo matemático. Esta capacidade tecnológica tem exercido, de forma sustentada, um fascínio sobre as audiências paralelo ao da própria ficção narrada, como se pode comprovar numa breve panorâmica pela sua história.

\section{Breve história do Cinema de Ficção Científica}

A génese do cinema de ficção científica pode ser encontrada no filme Voyage dans la Lune, de Méliès, em 1902. Nas duas décadas que se seguem, durante o período mudo, foram realizados alguns filmes que retrospetivamente se podem classificar como ficção científica, de que são exemplo The Comet (realizador desconhecido, 1910), o primeiro filme de catástrofe inspirado na passagem do cometa Haley, One Hundred Years After (realizador desconhecido, 1911), The Last man on Earth (Blystone, 1924), Aelita (Protazanov, 1924) e The Airship (Madsen, 1917).

Na década de 1920, assiste-se à consagração de Fritz Lang, um dos realizadores mais importantes para a história do cinema de ficção científica, principalmente pelo filme Metropolis (1927) que explora os perigos da tecnologia e da desigualdade social. Antes de partir para Hollywood, Lang 
realiza ainda Die Frau in Mond (1929), uma narrativa de viagem à lua. A influência de Lang faz-se sentir na ficção científica das décadas seguintes com a monumentalização dos cenários e o cruzamento entre a celebração tecnológica e a ansiedade da alienação, como em High Treason (Elvey, 1929), Just Imagine (Butler, 1930) e Things to Come (Menzies, 1936).

Na década de 1930, a fórmula dominante é a do cientista louco, misturando elementos da ficção científica e do terror. Frankenstein (Whale, 1931), Bride of Frankenstein (Whale, 1935), Invisible Man (Whale, 1933) e Island of Lost Souls (Kenton, 1933) combinam ciência com cenários sombrios, sublinhando os riscos da construção científica quando desvinculada do controlo institucional.

Nessa década e na seguinte, correspondentes à era dourada das pulp e à proliferação dos comics, surgem alguns filmes de super-heróis ${ }^{17}$, que ressurgirão na década de 1970 e novamente a partir da década de 1990. Flash Gordon (Stephani, 1936), Buck Rogers (Beebe and Goodkind, 1939) e Adventures of Captain Marvel (John English e William Witney, 1941) são exemplos dessa tendência, que contrasta com o tom sombrio e monumental dos filmes anteriores e com o tom paranoico da ficção científica da década seguinte.

A década de 1950 é marcada pela construção de uma identidade cinematográfica de género, que pode comprovar-se pelo número significativo de filmes com fórmulas narrativas idênticas e pelo sucesso que obtêm, fazendo da ficção científica um género popular. Esta tendência inicia-se em 1950 com o filme Destination Moon, produzido por George Pal e realizado por Irving Pichel, que é uma adaptação da novela de Robert Heinlein, Rocket Ship Galileo, publicada em 1947.

O sucesso do filme desencadeia um ciclo de cinema dedicado à temática espacial. No ano seguinte, são lançados The Day the Earth Stood Still (Wise), The Thing from Another World (Nyby), When Worlds Collide (Maté), e outros filmes de menor orçamento, como Flight to Mars (Lesley Selander),

17 James (1994:48) considera as narrativas de super-herói uma das criações mais eminentes da era pulp, que têm como características distintivas centrarem-se mais em ação do que em pensamento, em poder do que em responsabilidade, em agressão do que em introspeção e em satisfação do desejo do que na realidade, constituindo por isso uma influência negativa para a ficção científica. 
Flying Disc Man from Mars (Fred Brannon), Lost Continent (Samuel Newfield) e The Man from Planet $X$ (Edgar Ulmer).

O grande filme de 1952 foi Monkey Business (Hawks), uma comédia em que Cary Grant e Ginger Rogers interpretam um casal que, acidentalmente, toma um elixir da juventude e começa a comportar-se de modo cada vez mais juvenil e irresponsável. The New Adventures of King Kong (Willis O’Brien) é também um filme desse ano, cujo sucesso leva à produção de mais filmes de monstros, como The Beast from 20000 Fathoms (Lourié, 1953), Them! (Douglas, 1954), The Creature from the Black Lagoon (Jack Arnold, 1954), The Snow Creature (Lee Wilder, 1954), It Came from Beneath the Sea (Robert Gordon, 1954) e The Beast with a Million Eyes (David Kramarsky e Lou Place, 1955).

Ao longo da década são lançados outros filmes que exploram os perigos da invasão e a ansiedade nuclear que crescem com a consolidação da Guerra Fria, como acontece com Invaders from Mars (William Menzies, 1953), It Came from Outer Space (Jack Arnold, 1953), Phantom from Space (Lee Wilder, 1953) e War of the Worlds (Byron Haskin, 1954), This Island Earth (Newman, 1955), Forbiden Planet (Wilcox, 1956), Plan 9 from Outer Space (Wood Jr., 1956), Invasion of the Body Snatchers (Don Siegel, 1956) e The Blob (Irvin Yeaworth Jr, 1958), entre outros. A monstruosidade é explorada de múltiplas maneiras, seja de origem alienígena, seja como resultado de mutações genéticas acidentais ou intencionais que ocorrem num futuro próximo ou distante.

Os excessos cometidos na exploração destas temáticas fazem com que a ficção científica perca a respeitabilidade conseguida com os filmes iniciais. Pelo final da década, os seus filmes são vulgarmente designados bug-eyed monster films numa alusão ao recurso à monstruosidade como novum, esgotando o potencial narrativo e crítico do género pela repetição de ícones e fórmulas descredibilizadas.

Na década seguinte a ficção científica tenta reinventar-se, procurando novos temas e aproximações a outros géneros cinematográficos. Encontra-se como comédia em filmes como The Absent Minded Professor (Stevenson, 1961), The Nutty Professor (Jerry Lewis, 1963) ou Way...Way Out (Gordon Douglas, 1966), como terror em Village of the Damned (Wolf Rilla, 1960), 
The Birds (Alfred Hitchcock, 1963) ou Night of the Living Dead (Romero, 1968), ou numa forma mais pura, como em Planet of the Apes (Schaffner, 1968), The Satan Bug (John Sturges, 1965), The War Game (Watkins 1966), filmes em que se encontram preocupações tão diversas como evolução, armas nucleares, guerra biológica, direitos civis e confronto social. Na década de 1960 e início de 1970, merecerá destaque a obra de Kubrick que realiza Doctor Strangelove or How I Learned to Stop Worrying and Love the Bomb (1964), 2001: A space Odyssey (1968) e A Clockwork Orange (1971).

A ficção científica da década de 1970 é marcada por temas ecológicos e sociais, apresentando, em alguns casos, preocupação com as formas de utilização da tecnologia. Os filmes mais relevantes são The Andromeda Strain (Wise, 1970), Running (Trumbull, 1971), It's Alive (Cohen, 1973), Westworld (Crichton, 1973), The Stepford Wives (Forbes, 1975), The Terminal Man (Hodges, 1974) e The Man Who Fell to Earth (Roger, 1976).

O ano de 1977 marca a afirmação da ficção científica enquanto espetáculo cinematográfico com Star Wars (Lucas) e Close Encounters of The Third Kind (Spielberg) que apelam a audiências de todas as idades e colocam a alteridade no centro da ficção científica.

Na sequência destes filmes, e seguindo uma tendência idêntica de juvenilização, encontramos Superman (Donner, 1978), The Black Hole (Nelson, 1979), Star Trek - The Motion Picture (Wise, 1979) e E.T. (Spielberg, 1982). O tom de aventura espacial está também presente nas séries televisivas Battlestar Galactica (1978-80) e Buck Rogers in the 25th Century (1979-81).

A década seguinte dá continuidade a esta linha de aventura e sentimentalização em filmes como Back to The Future (Zemeckis, 1985), Cocoon (Howard, 1985), Explorers (Dante, 1985) e Weird Science (Hughes, 1985).

No entanto, nos anos 1980 assiste-se a um acentuar do tom crítico e distópico, inaugurado com Alien (Scott, 1979) e Blade Runner (Scott, 1982) que se mantém em Terminator (1984, 1991), Aliens (1986), Robocop (1987, 1994) e Total Recall (1990), em que a tecnologia é a categoria dominante. Este período corresponde à massificação do computador enquanto ferramenta de trabalho e de uso pessoal, podendo considerar-se que o cinema de ficção científica reflete as ansiedades geradas no cidadão comum pela crescente informatização do mundo. 
Em termos informáticos, a segunda metade da década é marcada pela redução de tamanho dos computadores pessoais, que se tornam portáteis, pelo triunfo do interface gráfico que facilita a utilização do computador, sem exigir competências técnicas específicas, e pela difusão da internet. Segundo Sherry Turkle (1995) na segunda metade dos anos 1980 há a sensação de domesticação da tecnologia. Esse sentimento é também dominante na ficção científica. Os filmes que no início da década assumiram a tecnologia como ameaça para a existência humana, lançam sequelas em que as máquinas são redimidas. É o caso de 2010 - The Year we Made Contact (Peter Hyams, 1984), Aliens (James Cameron, 1986), Terminator 2 (James Cameron, 1991) e Robocop 2 (Irvin Kershner, 1990). No entanto, este otimismo em relação à máquina não é permanente porque no dobrar do milénio filmes como The Matrix (irmãos Wachowski, 1999), Terminator 3 (Jonathan Mostow, 2003) e Terminator 4 (McG, 2009) voltam a centrar-se no confronto entre humanos e máquinas.

Tal como acontecera com a literatura em finais do século XIX, o sentimento finissecular é acompanhado por um incremento na produção do cinema de ficção científica, que, na década de 1990, se torna o género mais rentável do cinema norte-americano.

Nesta década mantém-se a aposta na serialização de alguns filmes que provaram ter sucesso nas bilheteiras, como acontece com Alien, Terminator, Predator, MIB e a saga The Matrix.

Acentuam-se neste género outras tendências gerais do cinema. Uma delas é a de hibridação com outros media, nomeadamente com a televisão, através de adaptações ao cinema de séries como os Jetsons - The Movie (William Hanna e Joseph Barbera, 1990), My Favorite Martian (Donald Petrie, 1999), ou da adaptação televisiva de filmes, como acontece com Stargate SG1 (1997). Para operar simultaneamente como filmes e como jogos, são concebidos produtos polivalentes como é o caso de Super Mario, Lara Croft e Resident Evil. Este fenómeno de migração dos jogos para o cinema pode comparar-se ao que se deu em décadas anteriores com os comic books, reforçando a ideia de que as várias formas de entretenimento são permeáveis e permitem rentabilizações mútuas.

Mantém-se também a tendência de fusão com outros géneros. Ao longo da década, assiste-se ao aparecimento de um conjunto de filmes de ficção 
científica que são simultaneamente melodramas familiares, como Deep Impact (Mimi Leder, 1998), Armageddon (Bay, 1998), Lost in Space (Stephen Hopkins, 1998) e Mission to Mars (de Palma, 2000), mas também é nos últimos anos do século xx que os filmes de catástrofe (disaster movies) têm maior sucesso.

Os filmes de catástrofe aproveitam os medos coletivos que acompanharam a transição de milénio, projetando os mais diversos desastres num futuro muito próximo. Alguns desses filmes retratam o medo de uma natureza sem controlo, perante a qual o homem, apesar de todo o seu poder tecnológico, é impotente.

Susan Sontag, num texto de 1965 intitulado The Imagination of Disaster ${ }^{18}$, considera que aquilo que caracteriza a ficção científica não é a ciência, mas o desastre. Para a autora, a essência do género é a imaginação do desastre e sua estética é a da destruição, convidando, não à reflexão mas a uma visão mais desapaixonada da violência. O cinema de ficção científica é, segundo ela, gerador de apatia em relação aos processos de radiação, contaminação e destruição, e retrata a alteridade e a estranheza familiarizando-a. Os diálogos tendem a ser banais e os filmes perpetuam lugares comuns sobre identidade, poder, conhecimento, felicidade, consenso social, culpa e responsabilidade. Apesar de retratarem os receios do desastre atómico, os perigos das radiações ou o medo da despersonalização, para Sontag não há nestes filmes qualquer criticismo social ou científico

Concordando-se ou não com Sontag, algumas das características que ela aponta ao cinema de ficção científica da sua época podem encontrar-se na ficção científica da transição do milénio. Os temas da catástrofe natural estão presentes em filmes como Armageddon, Deep Impact, Volcano (Jackson, 1997), Dante's Peak (Donaldson, 1997), The Day after Tomorrow (Emmerich, 2004), 2012 (Emmerich, 2009), o apocalipse nuclear pode encontrar-se nos filmes Terminator (Cameron, 1984 e 1991), a ameaça biológica em Outbreak (Petersen, 1995) e Resident Evil (Anderson, 2002), e a invasão do planeta por alienígenas em Independence Day (Emmerich, 1996), Mars Attacks! (Burton, 1996), War of the Worlds (Spielberg, 2005) e Cowboys \& Aliens (Jon

18 The Imagination of Disaster, in Redmond, 2004:40-47 
Favreau, 2011), comprovando que a imaginação do desastre está claramente presente no cinema de ficção científica.

De acordo com Maurice Yacowar ${ }^{19}$, o disaster film obedece a um conjunto de convenções que permanecem atuais, sendo a primeira a ausência de distância temporal ou espacial em relação ao mundo empírico. São filmes de proximidade temporal com o presente, sem uma iconografia específica além de imagens de destruição espetacular. Uma segunda convenção é a representatividade social das personagens, reforçando a sensação de que toda a sociedade está em perigo. Frequentemente é dramatizado algum tipo de conflito de classe, que acaba resolvido ou minimizado perante a ameaça global. O isolamento da comunidade ameaçada é também apresentado como uma das convenções, juntamente com a confiança no conhecimento especializado de uma das personagens, normalmente cientista, fundamental para o restabelecimento da ordem. Quase invariavelmente existe um subplot romântico e as instituições (políticas, religiosas e militares) revelam-se incapazes de responder à ameaça ou ataque, características que estão presentes nos filmes atrás referidos.

Na década de 1990, a informatização do mundo, a virtualização da realidade e a capacidade de criar artificialmente estímulos sensoriais e percetivos estão presentes num conjunto de filmes que traduzem, por um lado a incapacidade de apreender cognitivamente a realidade, por outro algum desencanto em relação ao mundo real, cada vez menos contido nos limites físicos impostos pela ancoragem no tempo e no espaço. Filmes como The Lawnmower Man (Brett Leonard, 1992), Virtuosity (Brett Leonard, 1995), Strange Days (Kathryn Bigelow, 1995), Dark City (Alex Proyas, 1998) e The Matrix (irmãos Wachowski, 1999) abordam a questão da estranheza do mundo, obrigando também a considerar o problema da fragilidade da identidade. Os filmes do início da década centram-se na mediação tecnológica da perceção, refletindo as ansiedades geradas pela dissolução de fronteiras entre real e virtual e desencanto pelas promessas de futuro não cumpridas. Jogos e dispositivos que permitem criar experiências alternativas da realidade estão presentes nos filmes The Lawnmower Man, Strange Days e The

19 The Bug in the Rug: Notes on the Disaster Genre, in Grant, 2003:277-295. 
Thirteenth Floor (Josef Rusnak, 1999), mas, à medida que a década avança, a alteração percetiva alastra a toda a realidade, obrigando a um questionamento simultaneamente epistemológico e ontológico da existência. Estas narrativas, de que Dark City e The Matrix são exemplares, classificam-se como narrativas de dissonância cognitiva por provocarem uma cisão entre a realidade aparente e um outro nível de realidade, invisível mas estrutural. A abordagem proposta enraíza-se na tradição filosófica ocidental, propondo a dicotomia platónica aparência/essência e perceção/conhecimento para explicar a duplicidade do real. No entanto, ao contrário de Platão, o mundo inteligível não é mais perfeito que o real, mas é resultado de uma ação negativa, seja alienígena no caso de Dark City, seja da tecnologia inteligente como acontece em The Matrix.

A ficção científica de dissonância cognitiva mostra a radicalização da incerteza cognitiva da existência pós-moderna. A desorientação, fragmentação, desintegração, dissolução de fronteiras e hibridação entre humano e inumano, real e virtual são temas dominantes nesta década, refletindo a crescente complexificação do mundo. A ansiedade milenar conduz a uma sensação de pós-futuro, de não cumprimento dos projetos tecnológicos da década de 1950 e do desejo reformista das décadas de 1960 e 1970.

O esbater das oposições e a permeabilidade entre as categorias traduz, por um lado a crescente aliança entre a tecnologia e o corpo, graças aos avanços da medicina e da robótica, por outro a crise do sujeito pós-moderno e a exaustão das próprias categorias enquanto ferramentas para pensar uma realidade cada vez mais fluida.

Estas tendências continuam a manifestar-se no cinema dos primeiros anos do século Xxi, com a conclusão de sagas, como The Matrix - Revolutions (irmãos Wachowski, 2003), Star Trek (J. J. Abrams, 2009) e Terminator Salvation (McG, 2009), a que se junta o acentuar dos medos em relação à clonagem ou manipulação genética, visível em filmes como The 6th Day (Roger Spottiswoode, 2000), Godsend (Nick Hamm, 2004) e The Island (Michael Bay, 2005), tornando-se uma das preocupações centrais no cinema de ficção científica do novo século, juntamente com as questões da perceção e da identidade que dela derivam (The 6th Day, Godsend, The Island, I Robot), ou que resultam do avanço tecnológico, como acontece nos filmes 
The Matrix, I Robot (Proyas, 2004), Paycheck (John Woo, 2003), Surrogates (Jonathan Mostow, 2009) e Avatar (Cameron, 2009), filme classificado como ficção científica mas que se aproxima mais da fantasia científica.

Comparativamente, poderemos considerar esta década menos criativa do que as anteriores, tese argumentável com a quantidade de adaptações de novelas e romances de autores reconhecidos pelo público, de que são exemplo os filmes I, Robot, baseado na obra de Isaac Asimov publicada em 1950, Minority Report, baseado num conto de Philip K. Dick publicado em 1956, Paycheck, também baseado num conto de Philip K. Dick, publicado pela primeira vez em 1953, Journey to the Centre of the Earth, baseado na obra de Jules Verne, publicada em 1872, e War of the Worlds, baseado no romance de H. G. Wells, publicado em 1898.

Sintomático de algum esgotamento criativo do género é também a onda de remakes de filmes de décadas anteriores, como acontece com War of the Worlds (Spielberg, 2005), remake do filme de Pal, de 1953, The Stepford Wives (Frank Oz, 2004), remake do filme de 1975 de Bryan Forbes, The Day the Earth Stood Still (Scott Derrickson, 2008), remake do filme de 1951 de Robert Wise, I am Legend (Francis Lawrence, 2007), remake do filme The Omega Man, realizado por Boris Sagal em 1971, e When Worlds Collide (Stephen Sommers), remake do filme de Rudolph Maté, de 1951. Esta estratégia estava já presente em filmes como The Invasion of the Body Snatchers (1956, 1978 e Body Snatchers, em 1993) e The Thing from another World (1951 e The Thing em 1982 e em 2011).

O filme Alien vs Predator também permite sustentar a tese de que há um decréscimo de originalidade narrativa, uma vez que se trata de um remix, uma combinação entre duas entidades alienígenas já conhecidas do público para gerar uma onda de novas narrativas, reflexivamente menos férteis que os originais.

No entanto, apesar da argumentável falta de criatividade, o cinema de ficção científica do século XXI continua a dominar as bilheteiras e a impulsionar o desenvolvimento da linguagem cinematográfica.

Reconhecida, ao nível da produção e da receção, como género autónomo, a ficção científica ocupa espaços de fronteira com o terror, a fantasia, a ação e o filme de catástrofe, apropriando-se de enredos e personagens 
de quase todos os outros géneros cinematográficos, mesmo os que se tornaram anacrónicos e desapareceram, de que é exemplo Cowboys \& Aliens (Jon Favreau, 2011), uma mistura entre western e ficção científica.

Por essa razão, alguns autores, como Farah Mendlesohn (2003), defendem a ideia de que a ficção científica não é um género mas um modo. O argumento apresentado por Mendlesohn é que, a ser um género, deveria fornecer uma ideia clara daquilo que se pode encontrar nas suas narrativas, tal como acontece, por exemplo, no romance, em que se sabe que duas pessoas se irão conhecer, entrar em conflito e apaixonar. Para a autora, aquilo que é distintivo na ficção científica é a capacidade de provocar o encantamento (o sense of wonder) e surpreender o espetador, não a estrutura narrativa em si, muitas vezes copiada de outros géneros. Poderá afirmar-se com segurança que um dos segredos do sucesso e longevidade da ficção científica está na gestão das expectativas do espetador e na imprevisibilidade dos enredos. Esta imprevisibilidade obriga a outros mecanismos de reconhecimento, que permitam aos espetadores algum tipo de antecipação que os leve à sala de cinema, de que é exemplo o remaking. Outro mecanismo, relativamente frequente nos filmes de ficção científica, é o recurso a atores que acabaram por ficar associados ao género, como acontece com Keanu Reeves (Johnny Mnemonic, The Matrix I, II, III), Tom Cruise (Minority Report, War of the Worlds), Will Smith (MIB I, II e III, I am Legend, I, Robot, Wild, Wild West, Independence Day), Sigourney Weaver (Alien I, II, III, e IV, Galaxy Quest, Ghostbusters, Wall-E, Avatar) e Arnold Schwarzenegger (Total Recall, Terminator I, II, III, Predator, Junior, The 6th Day).

O mesmo acontece com realizadores, como Steven Spielberg (Close Encounters of the Third Kind, E.T., Jurassic Park I, II e III, A.I. - Artificial Intelligence, Minority Report, War of the Worlds), James Cameron (Xenogenesis, Aliens, The Abyss, The Terminator, Terminator 2: The Judgement Day, Avatar), Paul Verhoeven (Robocop, Total Recall, Starship Troopers, The Hollow Man), Roland Emmerich (Universal Soldier, Stargate, Independence Day, Godzilla, 2012), Ridley Scott (Alien, Blade Runner, Prometheus) e George Lucas (Star Wars e THX 1138).

A serialização dos filmes funciona também como estratégia de reconhecimento, oferecendo continuidade narrativa e familiaridade de universos e 
personagens, como acontece em séries como Alien (I, II, III, e IV), Terminator (I, II, III, IV), The Matrix (I, II, III), M.I.B (I, II, III), Resident Evil (I,II, III, IV, V), Robocop (I, II), Predator (I, II), Star Wars (IV, V, VI, I, II, III) e os nove filmes Star Trek.

O recurso a estas estratégias facilita os processos de identificação que vão para além da mera classificação tipológica, fidelizando as audiências de um modo semelhante às revistas pulp.

É a capacidade de se apropriar de temas, enredos e estruturas narrativas de vários géneros, de se reinventar e de adaptar velhos textos a novas situações históricas e sociais do momento, conjugada com o facto de ter uma dimensão metafórica que permite uma apropriação de sentido adaptável a cada contexto, que fazem da ficção científica um dos géneros mais permanentes do cinema norte-americano, capaz de sobreviver ao western, ao musical e ao film noir, géneros que a evolução social e cultural tornou anacrónicos. A essência da ficção científica reside no facto de não oferecer a familiaridade do real concreto, nem mesmo a familiaridade de personagens ou enredos predeterminados, mas mover-se num leque infinito de possibilidades cujo único limite é o da verosimilhança. O horizonte de todos os tempos e espaços possíveis permite um número quase infinito de possibilidades de combinação de elementos de modo a superar continuamente as expectativas da audiência, ecoando as esperanças ou angústias do presente real e propondo formas de viver, evitar ou combater futuros que a audiência reconhece como possíveis. 


\section{ALTERIDADE, TECNOLOGIA, TEMPO E ESPAÇO NO CINEMA DE FICÇÃO CIENTÍFICA}

\section{Alteridade}

A alteridade assume-se como categoria dominante na ficção científica, mais do que o tempo e o espaço, usados frequentemente como meros contextos, ou a ciência e a tecnologia, que muitas vezes se limitam a fornecer os conhecimentos e dispositivos que permitem o encontro com as diferentes espécies, culturas e modelos de organização social.

Tratar a alteridade em ficção científica é, em última análise, refletir sobre o não humano, o que conduz a questões sobre a identidade e sobre a configuração dada à humanidade no encontro com o que lhe é estranho. A dicotomia estrutural em jogo é o Eu e o Outro, definindo-se cada conceito nesta oposição relativa.

Para Haraway (1991), o eu (self) representa aquele que não é dominado, o ser autónomo, poderoso, unificado, que se opõe ao outro, afirmado como contrário e, por isso, múltiplo, sem fronteira definida, pouco substancial. Seja para afirmar a sua supremacia, seja para mostrar as suas debilidades, o eu da ficção científica corresponde ao perfil dominante na cultura ocidental moderna: indivíduo, humano, masculino, caucasiano, heterossexual e habitante do hemisfério norte. Cada texto pode ser interpretado pelo grau de diferenciação e desvio que o outro introduz em relação a este modelo de identidade.

No entanto, o conceito de identidade deixou de poder encarar-se unidimensionalmente nas últimas décadas. Stuart Hall (1997) aponta cinco 
conceções teóricas que abalaram estruturalmente a identidade do sujeito moderno: o pensamento marxista interpretado pelos pensadores da década de 1960, a noção freudiana de inconsciente e o trabalho de Lacan, que sublinham que a identidade é uma construção gradual e difícil, que a criança vai fazendo na sua relação com os outros. Acrescenta o trabalho dos linguistas que, na sequência de Saussure, retiram ao autor o domínio absoluto sobre os significados dos enunciados que produz, as reflexões de Foulcault sobre a loucura e as instituições de vigilância do Estado moderno, os movimentos sociais das décadas de 1960 e 1970 que, criticando a ideologia dominante, apelam às múltiplas formas de identidade, destacando o feminismo por abrir a esfera doméstica e a sexualidade à contestação política e sublinhar o caráter adquirido das identidades, nomeadamente de género. Segundo o mesmo autor (1996:4) as identidades são construídas a partir da narração do self, envolvendo um processo que implica a imaginação e fantasia, sem retirar efetividade discursiva, material ou política à narração. Considera que a ficção científica é uma estratégia enunciativa que estabelece a possibilidade de construção da identidade a partir do encontro com a diferença, fornecendo modelos de eus em tempos e espaços outros.

Como exemplares do discurso da pós-modernidade, as narrativas da ficção científica refletem a crise identitária do sujeito pós-moderno, para quem o tempo, o espaço e a própria noção de realidade sofreram processos de compressão, distensão e fragmentação, impedindo a construção de noções estáveis e unívocas, num mundo em que os outros, os duplos, as sombras do self ocidental moderno, se assumem enquanto agentes de discurso e instâncias de poder.

Esta mutabilidade e plasticidade identitária do sujeito pós-moderno permitem imaginar vários tipos de alteridade, acentuando a sua centralidade na ficção científica. A ficção permite dramatizar o medo da perda do eu, da sua permanente fluidez e mobilidade e da permeabilidade às influências exógenas. O radicalmente outro da ficção científica fornece um espelho a partir do qual o eu se pode refletir e compreender, percebendo que a sua natureza é problemática e é, também ela, heterogénea e artificial. 
A dicotomia humano/não humano na ficção científica traduz-se fundamentalmente na dicotomia humano/alien. Em termos cinematográfico, pelo domínio da dimensão visual, o primeiro grau de diferenciação é sensorial. O alien é a corporização do inumano, dando forma física à estranheza. A morfologia da alteridade traduz simultaneamente as conceções e ansiedades biológicas e culturais dominantes no momento de produção do filme e o estado de evolução da tecnologia dos efeitos especiais. Mas a aposta na mera estranheza visual, do marciano verde aos exóticos alienígenas de M.I.B., apesar de ser eficaz em termos de espetacularidade e de contribuir para a construção da iconografia do género, nem sempre conduz a uma reflexão crítica sobre a diferença, como acontece, por exemplo, no filme Star Wars. No entanto, a maior parte dos filmes de ficção científica permitem uma leitura conotativa, metafórica, mais rica e que promove a articulação de discursos normalmente marginalizados, facilitando a reflexão crítica sobre as identidades e diferenças biológicas, sociais, e psicológicas.

Para efeitos de análise, poderá criar-se uma primeira categoria de alteridade cuja origem não é humana nem mecânica, que provém de um topos que não o mundo empírico e se pode movimentar numa escala omnitemporal. Este outro como alien, como estranho absoluto que não partilha qualquer herança biológica, histórica ou social e não habita o mesmo espaço tempo, distingue-se do alien humano, do outro enquanto eu, que coloca de forma mais dramática as questões da identidade e as várias formas de hibridação que podem originar o humano como alien ou o alien como humano. Neste grupo de aliens encontramos também clones e réplicas humanas, colocando-se as questões ontológicas da distinção entre original e cópia, aparência e realidade.

Numa terceira categoria de alteridade encontramos o outro como máquina, forma de alteridade típica das narrativas em que o novum é a tecnologia, instituída como o lugar do não humano, que o interpela e confronta. Topologicamente, são narrativas situadas no planeta Terra, e passam-se tendencialmente num futuro próximo do tempo zero da narrativa. Este outro enquanto máquina, nas suas múltiplas versões, traduz os modos de encarar a tecnociência ao longo das décadas em análise, sendo abordado por isso na categoria tecnologia. 


\section{Aliens não humanos}

O humano ganha novo significado através do encontro com o não humano porque se torna, ele próprio, estranho. Mas o não humano também só adquire significação quando é trazido à relação com o humano, porque nessa altura passa a fazer parte da experiência humana. O fenómeno que ocorre na ficção científica é, como Suvin descreve, o de familiarização do não familiar e desfamiliarização do familiar, e é isso que a torna cognitivamente fecunda.

É impossível pensar o absolutamente outro, imaginar o radicalmente diferente por necessitar de se ancorar no familiar, Pensar a alteridade é sempre pensar graus de diferença, nunca a diferença absoluta. O absolutamente diferente seria, também, sem significado. Dar sentido é tornar humano. O grande desafio da ficção científica é mostrar graus superiores de diferença sem perder as referências que permitem atribuir significação e, ao permitir dar sentido ao inumano, promover a compreensão daquilo que é especificamente humano.

Atribuir significado é sempre uma tarefa contextualizada, situada num momento da história e do desenvolvimento da ciência e tecnologia, implicando, por isso, a projeção dos valores e ansiedades presentes. Daí que os aliens da ficção científica sejam sempre construídos por analogia ou contraste com uma dada noção de humanidade, que, por sua vez, é construída por projeção do real no imaginário. Telotte (1995) usa o conceito de humanidade imaginada para se referir a este tipo de ficção através da qual se descreve, analisa e até prescreve a natureza humana, e se constrói a identidade utilizando os mecanismos de projeção e coesão que a diferença permite. No cinema de ficção científica anterior à década de 1950, a alteridade encontra-se no planeta Terra e é constituída por heróis importados dos comics ou por monstros produzidos pela ciência, numa relação próxima com o terror das lendas. A antropomorfização da alteridade é reveladora da incapacidade de pensar o radicalmente outro, talvez pela existência de estruturas de diferenciação social, cultural e política no seio da própria realidade.

Nos anos de 1950, com a afirmação da ficção científica enquanto género cinematográfico, há necessidade de uma maior imaginação da diferença, 
embora ainda fortemente ancorada no orgânico. A morfologia alienígena mantém traços antropomórficos, e a alteridade encontrada na Terra deriva, normalmente, de mutações nos organismo conhecidos, provocadas por efeitos imprevisíveis e indesejáveis dos avanços científicos.

É apenas a partir da década de 1970, por ação conjugada da dissolução de fronteiras conceptuais, afirmação de múltiplas diferenças sociais e políticas e desenvolvimento das tecnologias que permitem o aperfeiçoamento dos efeitos especiais no cinema, que a diferença assume contornos cada vez mais fantásticos, contribuindo para isso, de forma sustentada ao longo de várias décadas, a criatividade de Steven Spielberg e George Lucas.

O cinema de ficção científica acumula, desde então, uma vasta galeria de alienígenas, antropomórficos, xenomórficos ou polimórficos, benévolos, malévolos ou indiferentes, individuais ou coletivos, livres ou determinados, próximos ou distantes da compreensão humana.

Alguns autores, como Roberts (id.) apresentam os borg, no episódio The Best of Both Worlds e no episódio First Contact da série Star Trek, como uma das mais eficazes tentativas de pensar a alteridade. Tal como aparecem neste episódio, os borg representam tudo o que a Federação não é e, por isso, o seu modo de ser está para além da capacidade imediata de compreensão humana. Roberts sustenta esta tese mostrando as diferenças entre a Federação e os borg. A Federação tem uma cultura baseada na individualidade, na liberdade e autodeterminação. Por oposição, os borg são um coletivo em que a individualidade é irrelevante. A cultura humana é hierárquica. Os borg não têm centro de poder nem hierarquias. A Federação está enraizada, tem origem no sector 001 (Terra) e assenta em valores, crenças e ideologias que o espetador identifica como dando sentido aos indivíduos e às coletividades. Os borg não têm origem nem centro, não têm propósito ou sentido e não precisam dele. Em suma, os borg não têm noção de individualidade, centro, estrutura, ou propósito. Não têm liberdade nem autodeterminação, e não valorizam nada daquilo que os humanos valorizam, nem sequer têm a noção de valor. A relação com os borg não é maniqueísta. Os borg não representam o mal, mas uma coisa mais difícil de pensar: a estranheza. Não mostram a força, mas que a força é irrelevante, tal como a vida ou a morte individuais. Como diz um dos borg a Picard "Força é 
irrelevante. Liberdade é irrelevante. Autodeterminação é irrelevante. Devem obedecer". Perante a resposta de Picard, que diz preferir morrer a ser assimilado pelo coletivo borg, é afirmado que a morte é igualmente irrelevante.

Segundo Roberts, é esta indiferença pelos valores mais centrais da humanidade que torna os borg um caso de sucesso na imaginação do radicalmente outro. O elevado grau de diferença na estrutura social, mental ou valorativa dá-lhes uma maior riqueza interpretativa, podendo ser compreendidos como uma alusão ao comunismo ou conformismo, mas também como uma referência a estados epidémicos. Para Roberts os episódios seguintes e o filme First Contact, são uma desilusão, uma vez que não conseguem sustentar o grau de diferença inicialmente proposto. No episódio I, Borg a individualidade passa a ser importante e no filme aparece uma rainha, o que mostra que afinal eles têm um centro e uma hierarquia, aproximando-se das formas de organização social humanas. Deste modo deixam de ser o radicalmente outro e posicionam-se apenas como inimigo.

Independentemente do grau de diferença proposto pela alteridade ficcionada, a primeira grande divisão clara e consensual que se pode fazer em relação aos filmes centrados nessa categoria é entre os que a retratam de forma negativa e os que a mostram de forma positiva, numa polarização entre alien benévolos e alien malévolos, traduzindo, normalmente na proporção inversa, um otimismo ou pessimismo antropológicos.

No cinema de ficção científica há um claro predomínio da malevolência alienígena, que permite pensar a humanidade como categoria unificada e sublinhar a superioridade das características humanas por oposição ao não humano. No entanto, a consciência de que a humanidade e os seus inventos podem constituir um perigo para si própria e para o equilíbrio ecológico e até interplanetário, surge no cinema da década de cinquenta, na forma do alien Klaatu, o extraterrestre de The Day the Earth Stood Still, um dos primeiros filmes a abordar a oposição entre humano terreno e não humano vindo do espaço, e a inverter os polos do maniqueísmo.

The Day the Earth Stood Still é lançado em 1951, produzido por Julian Blaustein e realizado por Robert Wise. Baseia-se numa história criada por um dos editores da era dourada da ficção científica, Harry Bates, intitulada Farewell to the Master, e dá origem a um remake, realizado em 2008. 
Explora, como o filme The Thing, o tema dos objetos não identificados e dos seres extraterrestres que neles podem viajar. Começa com a imagem de radares que espreitam céus. O radar capta alguma coisa que se move através do planeta. A BBC anuncia que é um objeto não identificado que circunda a Terra a velocidades incríveis.

O relato da aterragem do disco é feito por uma das personalidades da rádio da época, num toque de realismo. Depois de aterrar, o OVNI é rodeado por soldados, tanques e artilharia, numa resposta militar à assumida ameaça alienígena.

Enquanto a vOz off radiofónica prossegue, a nave projeta a plataforma e aparece um ser com aspeto humano, Klaatu, que desce e anuncia "Viemos para vos visitar em paz e boa vontade”. Esta declaração não provoca qualquer reação no exército, que continua em sentido, e, quando Klaatu retira um objeto do seu uniforme, um dos soldados atinge-o.

Nessa altura, aparece Gort, um ser mecânico gigante que iguala o exército em capacidade destrutiva. Klaatu e Gort são agentes de uma federação intergaláctica que pretende transmitir uma mensagem para os líderes da Terra. Quando estes se recusam a reunir-se num único lugar por razões políticas, Klaatu decide conhecer o planeta por si mesmo. Foge aos seus captores com facilidade e instala-se numa casa onde se torna amigo de uma viúva, Helen, e do seu filho Bobby, com quem estabelece uma relação em que revela a sua gentileza e bondade. A criança coloca Klaatu em contacto com Barnhardt, um cientista. Klaatu tem esperanças que o cientista reúna os líderes da comunidade científica para concretizar a missão de avisar os seres humanos que a aliança intergaláctica não tolerará que a humanidade, na posse das tecnologias que permitem viagens espaciais e produção de armas nucleares, leve para o espaço o seu potencial destrutivo.

Barnhardt diz a Klaatu que terá de fazer uma demonstração de força para que acreditem nele e Klaatu consegue que a energia se desligue durante trinta minutos, o que faz parar o planeta. Klaatu é novamente perseguido e alvejado, e Helen procura a ajuda de Gort, que entretanto escapara do bloco de plástico onde havia sido preso. Juntos levam Klaatu para a nave e ressuscitam-no. 
Klaatu revive, liberta Helen e fala aos cientistas que Barnhardt entretanto reunira. Antes de voar pelos céus, explica-lhes a sua missão: avisar a Terra, no início da sua exploração espacial, que, se os perigos da energia nuclear ameaçarem a segurança de outros mundos, a polícia intergaláctica será forçada a destruir o planeta.

Em The Day the Earth Stood Still, a alteridade, na figura de Klaatu, aparece sob a forma positiva e é o ser humano que constitui um perigo para si próprio e para o equilibro cósmico. O alien é representado antropomorficamente e comunica com os humanos, numa ténue variação da mesmidade. Pode mesmo considerar-se que Klaatu representa o poder transcendente que vem oferecer salvação à humanidade. A sua personagem pode ser comparada a Cristo. Tal como Cristo, é ferido e morto pelos soldados e, tal como ele, ressuscita e deixa a humanidade entregue a si própria para escolher o rumo que irá seguir. Gort representa a alteridade tecnológica, mas é também retratado positivamente. Faz parte de um grupo de robôs a que foi atribuída a função de patrulhar a galáxia e garantir a paz, tendo o poder de destruir os mundos que não obedeçam às regras. O que os torna destrutivos é o cumprimento desapaixonado e objetivo das normas, tarefa que exige uma frieza mais facilmente atribuível a máquinas do que a seres vivos. Numa das passagens do filme, Klaatu explica a Helen que não há limites para o que Gort pode fazer se for provocado pelos humanos. No entanto, apesar do perigo potencial que Gort representa, The Day the Earth Stood Sitll não entra na categoria dos filmes tecnofóbicos. O poder do robô foi-lhe atribuído por seres com uma inteligência superior à humana, que abdicaram dos instintos, da violência e de parte da sua liberdade em favor da paz intergaláctica. A bondade de Klaatu, a sua "humanidade”, expressa na tolerância, é argumento suficiente para levar o espetador a acreditar que este é um estádio superior de desenvolvimento, a que o homem poderá aspirar mas pelo qual terá de lutar. Ao contrário do que acontece na maior parte dos filmes de ficção científica, os discos voadores de The Day the Earth Stood Still trazem o bem, a ordem e a possibilidade de a humanidade pertencer a uma comunidade superior. A exploração espacial e a energia nuclear representam a ameaça de destruição da espécie, mas também constituem aquilo que torna a humanidade 
digna da visita de Klaatu e de vigilância intergaláctica, uma espécie de entrada na maioridade planetária.

De acordo com o filme, é o poder político-militar, e não a ciência, que coloca a humanidade em perigo. Foi aos cientistas e não aos políticos que Klaatu conseguiu transmitir a sua mensagem, sendo à comunidade científica que é atribuída a responsabilidade e a esperança de que as suas palavras sejam tomadas em consideração. Apesar da consciência dos perigos que a racionalidade científico-tecnológica militarizada pode trazer à humanidade, acaba também por prevalecer uma esperança cautelosa em relação ao futuro.

O otimismo em relação à alteridade só é retomado no final dos anos de 1970 e início dos anos de 1980, contribuindo para isso a visão do realizador Steven Spielberg, como acontece em Close Encounters of the Third Kind e E.T. Herdeiros de Klaatu, aos visitantes alienígenas de Spielberg, para quem o perigo é a incompreensão humana, podem juntar-se Starman de John Carpenter (1984), The Man Who Fell to Earth, de Nicolas Roeg (1976) e The Brother from Another Planet, de John Sayles (1984). Como refere Kaveney (2005:41), são "figuras seculares de Cristo" que, como ele, fazem milagres e sofrem perseguições. Nesta perspetiva, pode considerar-se que o cinema, com algum atraso, recria as tendências literárias da ficção que utiliza o alien para mostrar a rigidez e injustiça das estruturas sociais e políticas humanas, de que é exemplo Valentine, o herói da obra de Heinlein Stranger in a Strange Land, publicada em 1961 e premiada com um Hugo Award.

Nas décadas seguintes, torna-se difícil encontrar um bom alien no cinema de ficção científica que chega às salas de cinema. Podem apresentar-se os exemplos de Cocoon (Ron Howard, 1985) e K-Pax (Iain Softley, 2001), embora tratem a questão da inserção social de idosos ou doentes mentais, os verdadeiros outros sobre os quais o espetador é levado a refletir, usando a ficção científica como dispositivo que garante a desfamiliarização do real e a capacidade de o olhar de modo diferente.

Nos anos de 1950 há um claro predomínio das narrativas de alteridade negativa, concretizadas em relatos de invasão que traduzem o mal-estar da Guerra Fria e da ansiedade nuclear, mas simultaneamente algum otimismo, não tanto em relação à humanidade, mas à capacidade de os Estados 
Unidos resistirem e combaterem qualquer ameaça externa através de alianças entre os vários poderes: científico, tecnológico, económico e militar.

Paradigmático da conceção de uma alteridade negativa, no sentido em que se institui como modelo de narrativa para muitos filmes futuros, é The Thing, realizado por Christian Nyby e baseado no conto Who Goes There? de John Campbell.

Neste filme, à imagem de The Day the Earth Stood Still, é a alteridade que se constitui como novum, estabelecendo a existência de mundos diferentes e a possibilidade de um futuro outro, resultante da eventual incapacidade de os humanos anularem a ameaça. Mas apesar de ter a alteridade como categoria dominante, o seu potencial reflexivo sobre as noções de humanidade e alteridade é baixo, o que está patente desde logo na coisificação do ser.

Os créditos iniciais do filme surgem entre neve e vento, e as letras que formam o título vão aparecendo uma a uma em fogo no ecrã. Uma figura solitária aproxima-se da base da força aérea em Anchorage, Alaska. A primeira personagem do filme é Ned Scott, um jornalista recém-chegado à base, à procura de uma história. Em pouco tempo, Scott está num avião com o Capitão Pat Hendry para investigar a queda de um objeto, registada pela base. A primeira referência ao contexto geopolítico surge com o levantamento da hipótese de que possam ser os russos os causadores da ocorrência. No local, os cientistas encontram uma área escura que se assemelha à cabeça e cauda de um espermatozoide, com um objeto no meio. Carrington sugere que se dividam e a rodeiem de modo a avaliar o tamanho da descoberta. Os homens dão passos atrás, esticando os braços e percebem que descobriram um objeto com uma forma redonda perfeita: um disco voador, o que gera algum entusiasmo patente na exclamação: "Finalmente conseguimos um! Encontrámos um disco voador!". Quando tentam derreter a cobertura, acabam por destruir acidentalmente a nave. No entanto, a alguma distância está enterrada uma outra nave debaixo do gelo e o seu piloto, 'a coisa' do título, é libertado pela explosão. Hendry, o militar, assume o comando da situação e manda preservar a coisa num bloco de gelo, impedindo o jornalista de comunicar a história ao mundo. 
Carrington, o cientista, quer começar a estudar imediatamente a criatura enquanto o militar insiste em esperar por ordens. O bloco de gelo é guardado num armazém aberto para se manter congelado. Um cobertor elétrico é acidentalmente atirado para o gelo por um dos homens, e o ser descongela. Hendry e outros encontram o bloco descongelado e a forma da criatura na laje. Ainda conseguem recolher o braço e mão do ser, decepados numa luta com os cães. O membro transforma-se numa espécie de vegetal. A procura pela coisa começa e o cientista e os seus técnicos tentam capturar a criatura sem o conhecimento dos militares, montando uma guarda à estufa quando lá encontram o corpo mutilado de um cão. No dia seguinte, descobrem os dois homens pendurados na estufa de cabeça para baixo com as gargantas cortadas. O primeiro contacto do espetador com a coisa acontece quando Hendry abre a porta da estufa e a descobre, com o braço completamente regenerado. A criatura tem uma forma humanoide mas de traços exagerados. Usa uma espécie de uniforme e uiva e rosna enquanto avança para a porta. Há uma antropomorfização da alteridade, ainda que esta tenha características que a afastam da espécie humana, como os sons que emite, a ligação ao mundo vegetal e a capacidade de regeneração que permite o crescimento do membro decepado. Apenas na versão de 1982, realizada por John Carpenter, quando a tecnologia de efeitos especiais já o permite, é que o alien assume o polimorfismo como caráter distintivo.

Os homens lutam contra o ser lançando-lhe fogo, o que o faz atirar-se por uma janela e lançar-se na neve. O confronto final acontece quando ele destrói o sistema de aquecimento do campo e o grupo se junta para fazer uma barreira ao gerador elétrico. Fazem uma armadilha com três linhas elétricas. O grupo é mergulhado na escuridão. Não se distinguem os vultos e o diálogo sobrepõe-se, tornando difícil distinguir quem é quem. No final, o alien é eletrocutado e o jornalista pode finalmente contar a sua história. O filme termina com um aviso: vigiem os céus!

Em The Day the Earth Stood Still e The Thing a ação passa-se na Terra, num tempo que poderia ser o presente, sem grande distanciamento em relação ao contexto social e político do mundo zero, contribuindo para aumentar a ansiedade e agravar a paranoia característica da década. Nenhum dos filmes avança um cenário claro de futuro, sublinhando a incerteza e o 
perigo, terminando ambos com um aviso à humanidade. É o filme The Thing, embora mais próximo do terror, que sugere maior otimismo antropológico. O perigo é o outro, o estranho, a alteridade não humana que vem dos céus e que obriga a humanidade a uma vigilância permanente das suas fronteiras celestes. Ao contrário de The Day the Earth Stood Still, em The Thing é a curiosidade científica e a não obediência aos regulamentos militares que constitui uma ameaça. No entanto, apesar do antagonismo presente ao longo do filme, no final é a aliança entre o poder militar e a ciência, entre a força e a inteligência, que permite a vitória da humanidade sobre a ameaça externa, o que confere ao filme um tom tecnofílico (ou cientofílico) suficiente para estabelecer uma visão otimista do futuro, não já de conquista mas, pelo menos, de capacidade de defesa perante ameaças externas.

A tendência de demonização do alien e de aproximação ao terror vai continuar ao longo da década de 1950, expressa em filmes como Invaders from Mars (William Cameron Menzies, 1953), It Came from Outer Space (Jack Arnold, 1953), Phantom from Space (Lee Wilder, 1953), War of the Worlds (Byron Haskin, 1953), Devil Girl from Mars (David Macdonald, 1954), Killers from Space (Wyott Ordung, 1954), Them! (Gordem Douglas, 1954), Invasion of the Body Snatchers (Don Siegel, 1956), Invasion of the Saucermen (Edward L. Cahn, 1957), The Brain Eaters (Bruno VeSota, 1958), I Married a Monster from Outer Space (Gene Fowler Jr., 1958) e Invisible Invaders (Edward L. Cahn, 1959), entre outros.

No final dos anos de 1970, inicia-se um novo ciclo de aliens malévolos, inaugurado com Alien em 1979. Segundo Quayle e Hunter ${ }^{20}$, o filme Alien e as suas sequelas identificam o inumano com a alteridade monstruosa e não deixam dúvidas que um bom alien é um alien morto.

Dentro das narrativas de aliens malévolos, podemos identificar subtipos. Numa categoria mais abrangente, pode considerar-se o alien malévolo como inimigo, estando em causa não apenas a sobrevivência da Terra mas, frequentemente, o equilíbrio do Universo. Os filmes que se enquadram neste grupo cruzam-se tipologicamente com os filmes de guerra, em que

\footnotetext{
20 in Cartmell et al., 1999:2.
} 
o confronto com uma ou várias espécies estranhas reforça a identificação e coesão da humanidade e faz prevalecer valores humanistas, moralmente inquestionáveis pela audiência. Normalmente não há indicação clara da motivação que leva à guerra nem uma preocupação em antropomorfizar o inimigo. A forma insetóide é frequentemente escolhida, provavelmente pelo facto de, no reino animal, os insetos se distanciarem dos mamíferos, quer morfologicamente quer ao nível do funcionamento biológico, do comportamento reprodutivo e da organização social. Um exemplo de filme de ficção científica que retrata os aliens simplesmente como inimigos, reduzindo-se com isso à categoria de filme de guerra, é Starship Troopers, do holandês Paul Verhoeven. Neste filme, um grupo de jovens americanos defende o Universo da ameaça de aliens com forma aracnídea que desmembram, esventram e decapitam grande parte do elenco. O filme é uma sátira à militarização, excessivamente gráfico para que a mensagem tenha efeitos reflexivos na audiência e para que possa ser feita uma leitura conclusiva da oposição entre humano e não humano.

Uma forma diferente de apresentar o alien como inimigo é colocá-lo como invasor. Nestes filmes, a potencial ameaça ao planeta e ao modo de viver humano retira qualquer ambiguidade moral em relação aos motivos da guerra. Os aliens declaram as suas más intenções tomando a iniciativa de atacar a Terra. A ameaça de destruição é coletiva, anulando as distinções internas e mobilizando a humanidade em torno do objetivo comum de lutar pela sobrevivência, dando corpo à fantasia da boa guerra, do moralmente justificável estado de united warfare contra um inimigo exterior, não humano. A subcategoria em que se enquadram continua a ser a de filme de guerra, mas a belicosidade é justificada pela necessidade de defesa contra a pior ameaça possível: o extermínio da espécie humana.

Os filmes que se inscrevem nesta linha narrativa são herdeiros da novela War of the Worlds, de H. G. Wells, que inspirou sucessivas versões cinematográficas. Dado o contexto em que foi escrito, o livro pode ser interpretado como uma crítica ao imperialismo, manifestando simpatia pelos povos colonizados. Mas a riqueza dos marcianos ou dos extraterrestres enquanto metáfora permite que eles possam significar qualquer coisa ou coisa nenhuma. 
O filme The War of the Worlds, produzido por George Pal e realizado por Byron Haskin, foi lançado em 1954. Em relação à novela, o filme transfere a ação de Londres para a Califórnia, onde uma chuva de meteoros cai sobre uma pequena comunidade. Quando um raio é disparado sobre a primeira equipa de investigadores e se descobre que meteoros idênticos caíram sobre todo o planeta, começa a desconfiar-se que se tratará de uma invasão. Máquinas com raios mortais levantam-se dos meteoros e começam a disparar, indestrutíveis perante a capacidade de armamento terrestre. Os marcianos acabam por morrer, não como resultado da potência militar, mas infetados por uma bactéria, um recurso da natureza, que prova ser superior ao poder dos humano e dos não humanos. As cenas de destruição presentes no filme são memoráveis e resultam de um enorme investimento em efeitos especiais. No entanto, além de tornar presente a ideia de outro não humano como perigoso invasor espacial, mais avançado em termos tecnológicos e militares e orientado pelo desejo de conquista e domínio, a leitura do filme pode enquadrar-se dentro das críticas apontadas por Susan Sontag aos filmes de ficção científica, por apostar no desastre como espetáculo e na devastação dos espaços simbólicos da cultura ocidental.

Nas últimas décadas, além do remake realizado por Spielberg em 2005, destacam-se dois filmes sobre invasão militar alienígena, ambos de 1996: Independence Day (Roland Emmerich) e Mars Attacks! (Tim Burton). Este último é uma sátira, com uma estética própria, que utiliza de forma irónica os lugares comuns da invasão, mas em que dificilmente se pode perceber o significado alegórico dos marcianos.

No Independence Day, como no Mars Attacks!, os pacifistas são rapidamente mortos, e um grupo que espera ser levado para a nave mãe, como no filme Close Encounters of the Third Kind, está também entre os primeiros a ser massacrado.

Kaveney (2005) considera que no Independence Day a invasão alienígena significa o medo homofóbico da homossexualidade. Para sustentar a sua tese, argumenta que as duas personagens masculinas principais, representadas por Will Smith e Jeff Goldblum, têm amigos que morrem durante o filme, um assumidamente gay e o outro brinca acerca da sua potencial relação homossexual com a personagem de Will Smith. Depois destes amigos estarem, 
como diz Kaveney, profilaticamente mortos, é que Will Smith e Goldblum podem, de forma segura e inequívoca, realizar os rituais masculinos de vitória e camaradagem que envolvem contacto físico e charutos. Refere ainda que, numa outra linha narrativa, a personagem interpretada por Randy Quaid torna-se o alcoólico da cidade desde que, segundo ele, fora raptado por aliens e sujeito a vários tipos de exame físico, incluindo retal. Psicologicamente destruído depois disso, redime-se lutando contra os aliens e, no clímax do filme, destrói uma nave entrando no seu interior e fazendo-a explodir. Esta sugestão de interpretação é reforçada por Michael Rogin ${ }^{21}$ que considera que os aliens do Independence Day se podem codificar como gayliens.

De acordo com Sean Redmond (2004), a mensagem subliminar dos filmes de invasão é que as pessoas normais devem estar vigilantes, sempre conscientes da ameaça que o outro constitui, e que o perigo se combate através da cooperação militar e científica.

Um outro subtipo de filmes centrado na alteridade malévola que compromete a integridade humana consiste naquilo que poderemos classificar como alien alienador. Filmes centrados neste tipo de ameaça dão origem a relatos de invasão corporal, de apropriação de identidade, de despersonalização e desumanização. Nestes casos, o alien constitui um perigo menos material, que não se pode combater com armas e que pode ser interpretada como o avanço silencioso das ideologias, da apatia social ou do conformismo, projetando as ansiedades acerca da organização social e da condição psíquica individual. Para Redmond (id.), estas narrativas podem representar uma crítica ao mundo moderno, crescentemente regulado por procedimentos racionais e tecnológicos, que implicam a docilidade e conformidade dos indivíduos. Representam simultaneamente um perigo coletivo e uma ameaça pessoal, e constituem um ataque direto àquilo que define a essência humana. O humano possuído torna-se desprovido de emoções e sem noção de identidade ou individualidade. A pessoa atacada não morre, mas desaparece. Deixa de ter centro e não se reconhece como indivíduo, por isso deixa de ser humano. O tema é importado dos filmes de terror: relatos de vampiros, lobisomens ou mortos-vivos apresentam as mesmas caracte-

21 apud Cartmell et al, 1999:3. 
rísticas, e, nessa medida, os filmes de alien alienador apenas deslocam a ameaça da floresta e da noite para um espaço mais vasto, também escuro, desconhecido e cheio de potenciais perigos.

A manutenção da vida e da aparente integridade do corpo permite que se possa ler este subtipo como uma metáfora de estados epidémicos ou da despersonalização da vida moderna. Grande parte dos filmes que abordam este tipo de alien derivam da novela Body Snatchers, de Jack Finney, publicada em 1955, que relata a invasão de uma pequena cidade americana por seres que crescem copiando a forma do indivíduo, destruindo o humano original. A novela dá origem, em 1956, ao filme de Don Siegel, Invasion of the Body Snatchers, em que aliens se vão gradualmente apropriando dos corpos da população da pequena cidade de Santa Mira perante a impotência do médico local e da sua namorada que assistem à substituição dos habitantes por réplicas sem emoções. Invasion of the Body Snatchers é um dos filmes mais respeitados da história do cinema de ficção científica, dando origem a dois remakes, um em 1978 (Philip Kaufman) e outro em 1993 (Abel Ferrara). A leitura que se pode fazer do filme depende do ponto de vista ideológico: os aliens podem ser entendidos como comunistas a infiltrarem-se no coração dos Estados Unidos, ou então como uma crítica interna à situação política americana, ao conformismo produzido pelo Macartismo. Apesar da leitura ambivalente, o filme é uma alegoria sobre o ataque ao individualismo pelas forças do conformismo e à perda de emoções no ser humano. No entanto, implica também uma reflexão sobre as oposições igualdade $v s$. diferenciação, livre arbítrio vs. obediência e coletivo vs. individual.

Os filmes Alien (1979, 1986, 1992 e 1997) são exemplares na entidade que propõe. O alien, além de inimigo, é invasor do espaço humano e violador da integridade física. Ataca, invade e possui, acumulando categorias. O primeiro filme, estando colocado na fronteira entre a ficção científica e o terror, explora o potencial do alien para despertar medo no espetador. O alien representa o monstruoso dentro dos limites da verosimilhança, o que o torna num dos monstros mais polivalentes e assustadores da história do cinema. O tratamento militar do segundo filme e a religiosidade do terceiro retiram alguma da carga metafórica e transformam a criatura simplesmente em inimigo ou em demónio, fazendo-o perder alguma da versatilidade 
presente no primeiro Alien, além do fator surpresa que garante o interesse do espetador durante todo o filme. No quarto filme (1996) o alien é explicitamente considerado um ser inteligente. Essa inteligência, que poderá resultar da sua hibridação com o humano, torna-o mais perigoso mas simultaneamente mais próximo e inspirador de simpatia, obrigando a novas articulações entre os conceitos de alteridade e identidade.

\section{Alien humano}

As narrativas que mais diretamente apontam para as questões ontológicas e antropológicas, para a determinação das fronteiras e do sentido daquilo que significa existir no mundo e ser humano, são aquelas em que a alteridade se constitui como desvio do próprio humano. Nestes casos, o outro descobre-se no interior do eu, por infeção, desvio ou mutação que provocam a ameaça ou destruição da integridade biológica, psicológica ou emocional.

Mas a fluidez dos processos identitários pós-modernos faz aumentar a diversidade de eus e, consequentemente, a diversidade de outros que nele se podem encontrar ou dele derivam, traduzindo múltiplos medos e ansiedades em relação ao que poderá comprometer a contenção imaginada do eu.

As narrativas que mais diretamente se podem enquadrar nesta classe são aquelas em que a alteridade se constrói por sobre-humanização ou por sub-humanização do humano. Em qualquer dos casos, trata-se de uma pós-humanidade que se concretiza em relatos de hibridação, cruzando-se muitas vezes com a fantasia ou versões pouco credíveis da ciência. O espetador não tem de fazer um esforço interpretativo porque reconhece no outro que lhe é apresentado quer a essência humana quer o desvio morfológico, fisiológico ou mental que constitui o novum e onde radica a diferença.

Ao contrário do outro como inimigo, invasor ou alienador, que congregam a humanidade em torno de um objetivo comum (sobrevivência ou vitória) e de uma categoria definidora, o alien humano sublinha o individualismo, a singularidade, a diferença no interior da mesmidade. Os outros como eus desafiam as leis físicas e sociais, insistindo na sua unicidade. 
Simbolizam o id ou o superego, e são normalmente um subproduto da racionalidade científica e tecnológica que está na sua génese.

Os super-heróis dos universos das editoras Marvel e DC Comics são um exemplo de como o estranho pode estar no aparentemente humano. O não humano está, normalmente, numa característica sobre-humana, mas é encoberto, constitui-se como identidade secreta, um segredo que o espetador/ leitor partilha com o herói. É a diferença que o individualiza, mas para que possa ser diferente tem de optar pelo anonimato, fundir-se com a classe média, sofrer por amor, ser invisível e cooperar com as instituições, situação cada vez mais problemática nos filmes recentes, em que a identidade e a diferença são trazidas para primeiro plano da narrativa. Spider Man (Sam Raimi, 2002, 2004, 2007), Batman (Tim Burton, 1989, 1992; Christopher Nolan, 2005), X-men (Bryan Singer, 2000 e Matthew Vaughn, 2011) ou The Incredible Hulk (Louis Leterrier, 2008) são exemplos de filmes centrados na hibridação entre humano e sobre-humano, que se transformaram em sucessos de bilheteira ao longo das últimas décadas, embora o seu estatuto enquanto filmes de ficção científica seja questionável, entre outras razões pela sua génese enquanto comics, pela apertada rede de intertextualidade e pela frequente desobediência às leis do mundo natural.

Se os super-heróis se apresentam como uma sobre-humanização resultante de uma mutação biológica ou fisiológica encoberta no anonimato, existem outras narrativas em que a variação do eu se faz por sub-humanização. O resultado são formas de alteridade construídas por monstrização do humano. Os monstros de matriz humana, herdeiros de Drácula e de Frankenstein, traduzem de forma mais aguda as ansiedades geradas pela transformação do humano, seja por mutação ou por engenharia genética.

Tematicamente, ao longo das últimas décadas, os aliens externos têm rivalizado com os aliens internos. As epidemias, armas biológicas, resultados da engenharia genética ou dos efeitos da destruição da biosfera, têm constituído um dos núcleos temáticos centrais da filmografia de ficção científica. De acordo com Telotte $(i d$.$) , uma das preocupações da ficção científica é o$ desejo moderno de tornar o corpo uma coisa manipulável e de criar um duplo humano. Para o autor, isso reflete-se no cinema dos anos de 1930 em narrativas de fronteira entre a ficção científica, a fantasia e o horror, tradu- 
zindo a preocupação com as experiências científicas que podem ser feitas sobre o corpo humano, transformando-o em outro monstruoso, algo que causa aversão ou repulsa. Dá como exemplo os filmes Frankenstein (James Whale, 1931), The Invisible Man (1933), Island of Lost Souls (1933) e Mad Love (1935). São histórias de constructos humanos, de fusão entre natural e artificial, resultados da vontade de criar uma outra versão do humano que origina cópias imperfeitas, monstros que, segundo Haraway (1991), servem para definir os limites da comunidade na imaginação ocidental.

A questão da manipulação do corpo humano, transformado em estranho, está presente, por exemplo, no filme The Island of Lost Souls (1933), de Erle Kenton, com remakes em 1977, realizado por Don Taylor, e 1996 por John Frankenheimer, ambos com o título The Island of Dr. Moreau, original da novela de H. G. Wells. Os filmes retratam as experiências científicas do Dr. Moreau. As suas criaturas, metade humanas, metade animal, causam a mesma repulsa que Frankenstein. São sujeitas a um regime disciplinar rígido com o objetivo de lhes impor uma humanidade que conflitua com os seus instintos bestiais. O inumano é, neste filme, associado à animalidade, permitindo o confronto entre instinto e valores, natureza e cultura, inato e adquirido.

As ansiedades relativas às transgressões que a ciência pode operar no corpo passaram, nas últimas décadas, a estar mais ligadas à tecnologia, originando narrativas que implicam a ciborguização do humano. No entanto as preocupações científicas e biológicas permanecem, quer ao nível da recriação do corpo humano, com a clonagem, quer na dimensão viral, potencialmente epidémica. As narrativas de epidemia, pelo grau de verosimilhança que têm, são as que mais diretamente permitem a identificação do espetador com o humano que, uma vez infetado, morre ou se transforma em inumano.

Outbreak (Petersen, 1995) e Twelve Monkeys (Gilliam, 1995) são textos exemplificativos desta ansiedade biológica. A sequência de abertura de Outbreak situa-se num contexto de guerra, em 1967, no Zaire. Médicos americanos descem vestidos com fatos espaciais, o que acentua o cenário de ficção científica. Tiram uma amostra a todos os mercenários e partem prometendo ajuda. Depois de partirem, o campo é bombardeado. Nada 
mais é explicado, o que reforça a noção de África como mundo estranho, não ocidental. Há, desde o início, uma militarização da situação, sublinhando a aliança negativa entre ciência e poder militar.

Uma das cenas de contaminação coletiva passa-se na sala de cinema, sublinhando no espetador a sensação de que é tão vulnerável como os infetados que vê no ecrã. O medo ancora-se, de uma forma mais ou menos clara, ao que, na época, se sabia acerca do HIV e, por outro lado, às ansiedades relativas a guerras biológicas e ao aparato científico-militar da contenção dos agentes patogénicos.

Resident Evil (Paul W. S. Anderson, 2002) centra-se na mesma ansiedade biológica conjugada com os perigos da militarização da ciência. A história gira em torna de um laboratório subterrâneo, gerido por uma Companhia, a Umbrella, que secretamente produz armas biológicas para os militares. A personagem principal, Alice (Milla Jovovich), é uma agente de segurança colocada na mansão que serve de entrada secreta para o laboratório. O plano de Alice é descobrir e revelar a verdadeira atividade da Companhia, mas o seu parceiro tem objetivos diferentes: roubar o vírus e vendê-lo no mercado negro. Para o conseguir, parte uma das cápsulas nos laboratórios, mas o computador central, Red Queen, ativa o sistema de defesa que consiste em matar todos os empregados do laboratório e provocar perdas de memórias nos que se encontram em andares superiores, como acontece com Alice. Mesmo sem memória, junta-se a uma equipa que investiga o que aconteceu nos laboratórios, e acabam por ser atacados pelos cientistas mortos, que, por efeito do vírus, se transformam em criaturas antropófagas. Quando Alice finalmente consegue fugir dos laboratórios e chegar à rua descobre que a cidade também já está contaminada, abrindo a porta às sequelas que se seguem.

Neste filme, o vírus criado pela Umbrella através da ciência com objetivos primariamente comerciais e secundariamente militares, é o agente que, ajudado pela tecnologia na figura do computador Red Queen, permite a transformação do humano no inumano violento, irracional e predador, figura mais característica dos filmes de terror do que da ficção científica.

Outra forma de retratar a alteridade sem a deslocar no espaço e no tempo é imaginando réplicas humanas. Já neste milénio, The 6th Day (Roger Spottiswoode, 2000) e The Island (Michael Bay, 2005) são filmes que tratam 
as questões da identidade e da moral perante os desafios da manipulação genética, nomeadamente da clonagem, instituída ao longo das últimas duas décadas como um espaço de reflexão sobre as questões da identidade e de encontro com o outro. O clone, apesar de morfologicamente igual ao mesmo, não deixa de se constituir como alteridade, como aquilo que o espetador pode identificar como ontologicamente diferente de si.

The 6th Day e The Island apresentam ângulos diferentes para debater a questão da identidade e da diferença de estatuto entre original e cópia. A ação de The 6th Day passa-se em 2015, num futuro próximo em que a clonagem de órgãos e animais é uma prática comum, mas a clonagem de humanos é expressamente proibida pela Lei Sexto Dia, numa referência bíblica ao dia em que Deus criou o ser humano. Um piloto de helicóptero, Adam Gibson (Schwarzenegger), regressa a casa para celebrar o seu aniversário e descobre um clone no seu lugar. O filme termina com Gibson a desvendar toda a trama que levou à sua clonagem, resgatando a família e recuperando a vida anterior com a ajuda do seu clone, para o qual forjam uma identidade que lhe permite viajar para a Argentina para que ambos possam ter uma existência singular e autónoma.

Apesar de propor uma solução conciliadora, o filme não deixa de partir da premissa que original e cópia têm um estatuto ontológico e existencial diferente e de questionar a legitimidade moral da clonagem de seres vivos.

No filme The Island, o espetador é levado a descobrir que os personagens, inicialmente identificados como humanos de igual estatuto, são, na realidade, clones geneticamente fabricados à imagem dos indivíduos a quem pertencem, tendo como função garantir a existência de órgãos compatíveis para eventuais transplantes. No final, o clones reivindicam o seu direito à individualidade e existência autónoma, que corresponde ao direito da cópia se instituir como original, do outro ser reconhecido como um eu. O argumento do filme permite reconhecer mais humanidade no clone do que no humano, invertendo o valor tradicional da dicotomia original vs. cópia e aproximando-se das noções propostas por Baudrillard de que o estatuto ontológico da cópia pode superar o da própria realidade.

Gattaca (Andrew Niccol, 1997) pode ser também apresentado como exemplo da abordagem do eu como outro, explorando o que poderia 
acontecer se a perfeição genética fosse considerada o critério de hierarquização social e se cada indivíduo valesse pelo seu ADN. Em Gattaca é retratado um futuro em que uma nova espécie de super-humanos se consegue através do controlo genético e de processos de eugenia. A avaliação genética condiciona o posicionamento social e as ambições individuais, permitindo uma nova forma de discriminação, que obriga Vincent Freeman, um jovem geneticamente inferior, a utilizar amostras do sangue, pele e urina de Jerome Eugene Morrow, um paraplégico geneticamente perfeito, para concretizar o sonho de voar pelo espaço e mostrar que a força de vontade supera qualquer noção de determinismo genético.

A mutação do humano, seja por sub ou por sobre-humanização, como resultado da ciência, da natureza ou de forças alienígenas, despertou o interesse da ficção científica desde a sua génese enquanto género, permitindo conceber a alteridade como desvio em relação à identidade, à noção de self culturalmente estabelecida, que é desafiada também pelas narrativas que deslocam a diferença para o alienígena pretendendo retratar de forma metafórica a diferença interna.

\section{Humano Alien}

Retomando as ideias de que o estranho não pode ser pensado sem ancoragem ao familiar, e de que a identidade nasce da diferenciação, não se poderá pensar o desconhecido sem que este remeta para uma qualquer realidade conhecida, nem pensar o outro sem que ele reflita a imagem do eu. Mas se nos casos dos filmes anteriormente referidos é o estatuto ontológico do indivíduo que é questionado ou afirmado de uma forma denotativa, clara, noutros casos este sentido tem de ser inferido e a narrativa interpretada, não de forma literal mas enquanto metáfora, de onde deriva muita da riqueza textual da ficção científica. A luta pelos direitos civis e a fragmentação da identidade pós-moderna obriga a procurar o outro que existe no interior da comunidade, a diferença social, política, sexual ou étnica subjacente à aparente uniformidade social e cultural, capaz de originar conflitos que, de acordo com a proposta de Lévi-Strauss, conduzem ao 
aparecimento de narrativas que os traduzam e resolvam ficcionalmente as oposições. Nessa perspetiva, poderá ler-se Men in Black (Barry Sonnenfeld, 1997, 2002 e 2012) como uma alegoria à imigração ilegal, Independence Day (Emmerich, 1996) como uma representação dos medos relativamente à homossexualidade, Predator (John McTiernan, 1989) como tradução das ansiedades relativamente aos negros, e Species (Ronald Donaldson, 1995) como manifestação das inquietações geradas pela afirmação do feminino.

Em cada um dos casos referidos, a metáfora traduz os receios relativos às minorias, as ansiedades geradas pelo multiculturalismo e pelas diferença sexual e de género. Uma vez que a alteridade é construída a partir de e por oposição ao self ocidental (caucasiano, homem, heterossexual), estes textos permitem leituras rácicas, feministas e queer, os outros culturais que se reveem nas propostas de alteridade da ficção científica, ainda que nem sempre representados na figura do alien.

A ficção científica, enquanto imaginação do futuro, permite postular um tempo em que a igualdade de género é uma realidade. No entanto esse movimento imaginativo não deixa de estar vinculado às representações vigentes no mundo zero. Per Schelde (1993) divide a imagem feminina na ficção científica em cinco estereótipos: mulher enquanto cuidadora, enquanto geradora de crianças, como objeto sexual, enquanto ser terreno e conservador de laços e como agente de socialização ${ }^{22}$. Exemplifica estes estereótipos recorrendo a filmes como The Fly (Kurt Neumann, 1958), em que Helene é a esposa de Andre, o cientista cuja experiência origina a metamorfose em homem mosca, e o remake de 1986 (David Cronenberg), em que Veronica (Geena Davis) desempenha o papel que cabia a Helene, não já como esposa passiva, mas como profissional, confidente e amante. Helene toma conta da casa e do filho e sente-se amedrontada com o trabalho científico que o seu marido leva a cabo na cave. Veronica, por seu lado, é uma mulher independente, uma jornalista que escreve sobre ciência e que procura Seth (Jeff Goldblum), o cientista, para escrever um artigo sobre as suas investigações, acabando por envolver-se romanticamente com ele.

22 No original: "women as nurturers, producers of children, sex objects, earthy and homebound beings, and socializers." p. 71. 
No entanto, apesar das diferenças e dos quase trinta anos que medeiam os dois filmes, Helene e Veronica tornam-se meros duplos femininos, definidas pela relação que têm com os homens e assumindo o papel de cuidadoras quando as experiências que eles levam a cabo resultam na sua monstrização.

O segundo estereótipo, de acordo com Schelde, está também presente nos dois filmes. Na versão de 1986, a questão da maternidade é colocada de modo mais ambivalente porque Veronica tem dúvidas sobre se deve ou não levar a gravidez até ao fim, mas acaba por manter a criança, assumindo a maternidade como valor e permitindo a serialização do filme.

O estereótipo da mulher como objeto sexual está presente ao longo de toda história da literatura e do cinema. Schelde dá como exemplo de exploração deste estereótipo na ficção científica o filme The Brain that Wouldn't Die (Joseph Green, 1962). Neste filme, a noiva de um médico cientista sofre um acidente e apenas sobrevive a sua cabeça, que o cientista mantém com a ajuda de máquinas enquanto procura um corpo sensual para ligar à cabeça decepada. O filme não trata da questão da identidade feminina, mas do desejo masculino que fragmenta a mulher, separando as dimensões afetiva e sexual.

O quarto estereótipo é o da mulher terrena, que mantém o homem ligado a si com o seu amor, e o quinto diz respeito ao seu papel enquanto agente de socialização, já que, segundo Schelde, por norma as mulheres têm mais medo de violar a ordem socialmente aceite e desobedecer às regras. No entanto, as últimas décadas têm abalado estes dois estereótipos, quer de forma explícita quer de forma implícita. Por exemplo, o filme The Stepford Wives (Bryan Forbes, 1975, com remake de Frank Oz em 2004) é um dos primeiros filmes de ficção científica a abordar explicitamente o papel da mulher na sociedade contemporânea. Joanna Eberhart (Katharine Ross em 1975 e Nicole Kidman em 2004) é uma nova-iorquina que se muda para a pequena cidade de Stepford por insistência do marido, estranhando a docilidade das esposas que lá vivem, que assumem satisfeitas o seu papel de mães, cozinheiras e donas de casa sem qualquer outro desejo ou expectativa. Acaba por descobrir que as verdadeiras mulheres, independentes e inconformadas, vão sendo assassinadas pelos seus maridos e substituídas por androides submissos. A ansiedade presente não é provocada pela 
tecnologia, mas pela diferença de géneros e pelas expectativas que lhes estão associadas num momento em que o movimento feminista se afirma e as mulheres reclamam para si mais do que aquilo que os estereótipos enunciados por Schelde propõem. Nos anos seguintes, a imagem da mulher e o modo como as narrativas de ficção científica a inscrevem nos estereótipos altera-se.

Uma das formas de valorização das personagens femininas é a sua masculinização, transformando-as em fêmea homem (female man). Um exemplo é Brainstorm (Douglas Trumbull, 1983), filme que explora a relação de uma cientista, Lillian Reynolds (Louise Fletcher) com a sua criação, uma máquina que grava pensamentos, sentimentos e perceções sensoriais. Apesar de ser uma das primeiras personagens femininas no cinema de ficção científica a desempenhar um papel ativo na construção da ciência e na criação de tecnologia, a sua caracterização corresponde ao estereótipo de cientista masculino sem explorar a sua dimensão feminina. Natalie Wood também faz parte do elenco como uma das cientistas, casada com o colega de investigação de Reynolds, morre durante as rodagens, comprometendo a conclusão do filme, que acaba por assumir um papel relativamente marginal na história da ficção científica.

Os anos de 1970 marcam um ponto alto no tratamento das questões de género na literatura de ficção científica, com a publicação de um número significativo de textos que Joanna Russ classificaria mais tarde como utopias feministas, e que podem servir de fundo para o aparecimento da primeira heroína do cinema de ficção científica: Ellen Ripley no filme Alien (1979).

No entanto, a escolha de Ellen Ripley para heroína pode ficar a dever-se, não tanto ao impacto do feminismo no modo de conceber e retratar as políticas de género, mas ao filme Alien estar na fronteira entre a ficção científica e o terror, desempenhando Ripley o papel de rapariga sobrevivente, a final girl dos filmes de terror típicos dessa mesma década, embora vá muito mais longe, fazendo-o sem qualquer auxílio masculino, num ambiente radicalmente estranho e salvando a humanidade no seu processo de sobrevivência.

Tal como Ellen Ripley, Sarah Connor (Linda Hamilton) é outra heroína do cinema de ficção científica que mostra a versatilidade e força femininas, 
ilustrando claramente as alterações na perceção do papel da mulher que ocorrem entre a década de 1980 e a de 1990.

No primeiro filme Terminator (James Cameron, 1984), Sarah é uma jovem atraente, ingénua, com um aspeto quase infantil, um emprego mal pago e sem grandes preocupações além de divertir-se. Ao longo da narrativa assume-se como objeto de amor e desejo de Kyle Reese, o humano enviado do futuro para a proteger, e torna-se responsável por gerar, cuidar e educar uma criança que crescerá para ser o futuro líder da humanidade. Corresponde a vários estereótipos femininos, encerrando ainda a simbologia cristã de ter sido escolhida para dar à luz o salvador, filho de um ser que não poderia, pelas leis da lógica e da física, ser seu pai.

Mas, apesar da aparente fragilidade revelada por Sarah, ao longo do filme vai-se revelando autónoma e capaz, fazendo o espetador acreditar que desempenhará eficazmente os seus vários papéis, nomeadamente o de mãe do líder da oposição humana na guerra contra as máquinas.

No filme seguinte, de 1991, Sarah é a antítese da jovem desprotegida que o espetador conhecia. O seu corpo musculado torna-a uma versão feminina do exterminador que enfrentara no filme anterior, mostrando que as oposições humano/máquina e homem/mulher podem ser superadas na figura da mulher, através da assimilação da máquina e do homem. No início do filme Sarah está internada num asilo para pessoas com problemas mentais onde é exibida como objeto clínico, atestando que a superação do estereótipo feminino não é isenta de custos e não está conforme aos limites da normalidade. Mas, apesar disso, Sarah representa a capacidade humana de modelação, de adaptação às circunstâncias, de sobrevivência em ambientes adversos e de resposta às exigências que são colocadas. Neste filme ela não é apenas a mãe de John Connor, mas ela própria é profetisa e salvadora da humanidade. Apesar da resistência física que o corpo musculado lhe confere e da aparente ausência de emoções, Sarah mostra não ter perdido a empatia humana ao ser incapaz de matar Miles Dyson, o responsável pelo computador Skynet que conduzirá a humanidade à Terceira Guerra.

Passível também de uma leitura de género e da fusão entre humano e máquina é a inversão de papéis que acontece entre Sarah e o exterminador, o androide masculino que no segundo filme se transforma numa 
figura paternal a quem Sarah atribui a responsabilidade de proteger e acarinhar John Connor.Depois de Ellen Ripley e Sarah Connor, as heroínas de ação (action babes) tornam-se frequentes nos vários géneros cinematográficos, substituindo as big bosomed babes de que é exemplo Jane Fonda em Barbarella (Roger Vadim, 1967). As actions babes de maior sucesso são Lara Croft (Angelina Jolie) e Alice (Milla Jovovich) do filme Resident Evil, ambas importadas dos jogos de computador, mas também Demi Moore em G.I. Jane (Ridley Scott, 1997), Geena Davis em Cutthroat Island (Renny Harlin, 1995) ou Michele Pfeifer em Batman Returns (Tim Burton, 1992). Neste filme, Pfeifer interpreta o papel de Selina Kyle, uma jovem solteira tímida que vive rodeada de gatos num apartamento ultra-feminino e que é abandonada pelo namorado por the ter ganho num jogo de ténis. Depois de ser atacada pelo seu chefe, Selina resolve fazer um fato e transformar-se em Catwoman, uma vingadora solitária. O drama de Catwoman é não poder amar sem voltar a ser a frágil Selina, e por isso foge de Batman, mostrando que a independência feminina implica perdas emocionais.

Apesar de o herói masculino ainda ser a figura dominante no cinema de ficção científica, representando a mulher os valores em perigo que é necessário salvar, as personagens femininas assumem cada vez mais protagonismo, desviando-se dos estereótipos propostos por Schelde ou da alteridade alegada pelas leituras feministas, e refletindo as alterações na atribuição dos papéis de género que ocorrem na própria realidade.

A leitura rácica dos filmes de ficção científica também é frequente. Um dos textos mais analisados é a série televisiva e os filmes Star Trek. Apesar da vontade expressa de Gene Roddenberry em representar um futuro sem discriminação, Mia Consalino (apud Roberts, 2000) considera a série tacitamente racista. Para sustentar a sua tese aponta a marginalidade da personagem Uhura e as características da espécie Klingon como representações estereotipadas do afro-americano: raça guerreira, com emoções fortes e manifestações físicas de poder, em contraste com o controlado, inteligente e diplomático Capitão Jean-Luc Picard. Roberts (2000) considera que Consalino não faz justiça à sensibilidade multicultural e rácica de Star Trek, patente em personagens como Geordi, representado por LeVar Burton, um ator afro-americano que ganhou popularidade na série 
Roots e que não tem nenhum dos atributos estereotipados da masculinidade negra: é um especialista informático, dedicado ao trabalho, tímido, amigo de um robô e cego, o que, mais do que a cor, gera ocasionalmente alguma discriminação.

No entanto, principalmente no cinema da década de 1980, é frequente uma demonização direta do negro. Roberts aponta como exemplo o filme Alien argumentando que o ser alienígena, uma entidade malévola, tem a pele escura, é representado por um ator negro e ataca as vítimas de forma violenta e violentadora no interior da nave (símbolo da cidade industrial), representando os medos da classe média caucasiana em relação à violência urbana. Mais explícito é o filme Predator (McTiernan, 1987), em que o ser alienígena tem rastas, habita na selva e ataca colonos brancos de forma violenta. Alien e predador acabam por ser controlados e mortos por heróis caucasianos, pondo fim à ameaça.

A partir da década de 1990 a tendência inverte-se e o cinema de ficção científica passa frequentemente a retratar o afro-americano de modo positivo, como um auxílio essencial na recuperação dos valores centrais da humanidade.

Esta tendência está patente em filmes como Johnny Mnemonic, em que Johnny é ajudado por T-Bone (personagem representada por Ice T, um rapper afro-americano) e o seu grupo. Também se encontra em Virtuosity, filme em que o próprio herói (Denzel Washington) é um afro-americano ex-polícia caído em desgraça, que põe a sua vida em risco para salvar uma mulher branca e a sua filha do assassino virtual SID 6.7. Comprova-se ainda em Strange Days (Kathryn Bigelow, 1995), filme em que Mace (Angela Bassett) é uma guarda-costas afro-americana que se dedica a proteger Lenny, o herói branco, salvando-o e resgatando-o com o seu amor. Um dos subtemas do filme é a tensão rácica, uma vez que todo o enredo se desenvolve em torno do assassinato de Jeriko One, um músico negro que, com música e discursos inflamados, mobiliza a população de Los Angeles contra as forças policiais corruptas e racistas.

Men in Black (1997), lançado um ano depois de Mars Attacks! e Independence Day, é uma narrativa de alien invasor que representa uma metáfora à imigração ilegal nos Estados Unidos. A premissa do filme é a de que os 
aliens já existem entre nós, disfarçados de seres humanos, sujeitando-se a políticas de imigração e vigilância. Os aliens não são necessariamente malévolos nem benévolos, e os seus objetivos não são militares nem ideológicos. Vivem ilegalmente no planeta, adotando ou adaptando os hábitos e regras humanos, mas representam um potencial perigo para a humanidade, por isso, são monitorizados e controlados pela organização secreta M.I.B., criada exclusivamente para esse fim.

Kaveney (2005) aponta outros aspetos interessantes no filme, nomeadamente o significado da cor preta. O filme começa com a escuridão do espaço na primeira imagem. Depois avança para o preto do carro, do fato, dos óculos e, finalmente, com o recrutamento de Jay (Will Smith), para a cor da pele. Negro é a cor da invisibilidade, do anonimato, assumida como a cor da institucionalização, do poder, da vigilância. Ao contrário dos homens de preto, que, mais do que anónimos se pretendem indiferenciados (destacando-se), os aliens vestem roupas coloridas e são visualmente diferentes (dissimulando-se). O neuralyzer, instrumento que apaga a memória, é um gadget igualmente interessante. Serve para apagar o conhecimento de que os aliens vivem entre nós, ou, pelo menos, para apagar o conhecimento da sua diferença. Para os humanos que não pertencem ao M.I.B. ou que foram 'neuralizados', os aliens são versões do humano, nunca reconhecidos como outro. Mas enquanto os aliens são explicitamente apresentados como exuberantes, excessivos e infantis, a própria humanidade, aparentemente superior, é retratada como insignificante e pueril, sem valores definidos ou moral clara, além da de que os mecanismos de vigilância e controlo permitem o funcionamento de uma realidade que não é o que parece. Apesar de aparentemente marginal, a questão da perceção é o tema central do filme.

Tal como acontece com a representação fílmica das mulheres, a ficção científica das décadas de 1990 e 2000 é politicamente mais correta e tolerante com a diferença cultural ou rácica, assumindo um tom multicultural que se afasta das metáforas mais explícitas das décadas anteriores, permitindo leituras mais ambivalentes.

Mulher e negro, tomados metafórica ou literalmente, são atualmente representados como parte integrante do self ocidental e, mesmo quando desempenham papéis secundários, são retratados como pares e não como 
lugar da diferença. Os fenómenos migratórios, terrestres ou intergalácticos, são também abordados de modo diferente. Na década de 1980 eram frequentes as narrativas de imperialismo terrestre, de movimento para o exterior, implicando a noção de conquista e colonização espacial, mas nas décadas seguintes esta tendência foi-se desvanecendo até desaparecer, deslocando-se a ação dos filmes de ficção científica para um planeta Terra cada vez mais multicultural, que contém ou recebe diferença.

A oposição irreconciliável encontra-se na figura do alienígena, do absolutamente estranho, e não naquilo que é humano, embora diverso na forma, origem, prática ou tendência. Clones, mutantes e heróis, ainda que diferentes, permitem a reconciliação do eu com o outro. Apenas o alien é lugar de diferença absoluta, do absolutamente inumano. As narrativas de hibridação humano/alien são de possessão ou de contaminação, de destruição da humanidade. Com a exceção de raros casos, situados principalmente nas décadas de 1950 e 1970, a alteridade que vem do espaço é retratada como malévola, o verdadeiro inimigo contra o qual os humanos se devem unir para defender os valores centrais, anulando as diferenças internas e congregando os esforços das várias agências de poder e conhecimento, colocadas ao serviço da causa mais nobre: a defesa da humanidade.

\section{Tecnologia}

A tecnologia, à imagem da alteridade, permite pensar as fronteiras do humano e do inumano, tomando como dicotomia central os binómios humano/máquina e natural/artificial. Nestes casos, a tecnologia, nas suas diversas manifestações, constitui-se frequentemente como uma ameaça à espécie, ao modo de vida humanos e até à própria natureza. Mas serve também de mediadora entre o ser humano e o que lhe é estranho, o presente e o passado ou o futuro, ou ainda entre a Terra e outros espaços, constituindo-se como dispositivo que permite o posicionamento físico e temporal da própria narrativa. Pode, por isso, ser encarada de modo positivo ou negativo, otimista ou pessimista, originando tecnofílias ou 
tecnofobias de acordo com as visões pessoais dos autores e as ansiedades do momento histórico de produção dos textos.

Colateral à antinomia humano/máquina, é também tratada a relação racionalidade/emoção, central no pensamento moderno e pós-moderno. A modernidade elegeu a racionalidade como conceito a partir do qual se pensa o humano. O não humano é, por oposição, o irracional, o não pensante, o pulsional, instintivo, animal. À razão caberia a função de controlar a emoção de modo a garantir a correção dos conhecimentos e processos mentais.

Ao longo do século xx, com a criação de máquinas capazes de assegurar as funções mecânicas de modo preciso e as tarefas de armazenamento, tratamento e difusão de informação de forma rápida e eficaz, o núcleo identitário da humanidade foi deslocado. Já não é a racionalidade, a capacidade de produzir conhecimento correto do ponto de vista lógico e gnosiológico, que define o ser humano. Essa passa a ser uma competência que se pode atribuir à tecnologia, ao não humano. A definição do homem pode, assim, deixar de ser feita por oposição ao animal e passar a fazer-se em relação ao computador. A máquina pensante, capaz de substituir o ser humano porque liberta da dimensão biológica e afetiva, torna-se uma das ansiedades do último século. Paralelamente, dá-se uma revalorização da emoção, que passa a ser considerada inseparável dos processos mentais. Na pós-modernidade, o sentir é tão importante como o pensar. O não humano deixa de ser aquilo que não pensa e passa a ser aquilo que, pensando, é incapaz de emoção ou sentimento. A tecnologia, criada para replicar os processos mentais humanos de modo preciso, frio e mecânico, passa a ser lugar do inumano. Daí que desempenhe um papel tão importante numa antropologia do futuro e, como refere Bukatman (1993:10), a ficção científica constitua um "espaço de acomodação para uma existência intensamente tecnológica”, fornecendo versões positivas ou negativas da tecnologia, principalmente nos espaços de intersecção entre o humano e o tecnológico.

Por detrás das versões positivas da tecnologia podemos encontrar resíduos do mecanicismo moderno, que via o cosmos como uma máquina e os seres vivos como autómatos. Esta visão do mundo faz triunfar a revolução industrial do século XIX, mas gera atitudes ambivalentes em relação às máquinas. O movimento romântico e as reflexões levadas a cabo pela 
filosofia, por exemplo, podem ser lidos como protestos ou alertas em relação à excessiva mecanização do mundo.

Vários são os filósofos que refletem sobre a importância da técnica na vida do ser humano, nomeadamente Heidegger (2002), que conclui que o mundo moderno sobrevaloriza o pensamento que calcula, aquele que rege a ciência e a tecnologia. Este pensamento converte o mundo num objeto conformado aos cálculos e previsões e obtém resultados eficazes, instituindo-se, por isso, como o modo dominante de pensar. Mas, ao fazer uso da tecnologia o homem descobre novas tecnologias, mais avançadas, que permitem o domínio da natureza. Ao conquistá-la para seu uso próprio, acaba por a destruir, colocando em risco o futuro do mundo tal como o conhecemos. Sugere como solução uma relação cautelosa com a tecnologia, que implique dizer não aos seus objetos quando apenas oferecem a sedução do que já está pronto, e não considera a técnica uma coisa em si, possuidora de uma autonomia que anule a vontade individual.

O cinema de ficção científica é um reflexo desta ambivalência teórica em relação à tecnologia. As suas narrativas, frequentemente tecnofóbicas, traduzem os medos de domínio, alienação e perda de humanidade que Heidegger sublinha, funcionando como um eco difusor das reflexões filosóficas, pouco orientadas para as massas.

Telotte (1995) destaca as narrativas sobre o corpo tecnológico, seja robô, ciborgue ou androide, por manifestarem a necessidade de retratar a ambivalência dos nossos sentimentos em relação à tecnologia, as crescentes ansiedades acerca da nossa própria natureza e uma espécie de medo evolucionário de que essas entidades tecnológicas pressagiem o nosso desaparecimento, que poderá ocorrer por destruição ou por assimilação do orgânico e do não orgânico. A tecnologia pode, assim, ser concebida como alteridade, como não humano, como elemento opositor ou como lugar de fusão, de conciliação, de encontro do humano com uma outra dimensão da sua própria natureza, mas que lhe é estranha. Em qualquer dos casos permite a reflexão em torno da segunda antinomia proposta por Haraway (1991), a de humano/máquina, que envolve um posicionamento em relação aos outros binómios que lhe são adjacentes, como razão/emoção, natural/ artificial, criação/criatura, liberdade/determinismo e mecânico/espontâneo. 


\section{Outro Máquina}

A ideia de que o ser humano pode ser substituído pelas máquinas, mais potentes e eficientes, não é recente. Desde o livro R.U.R. ${ }^{23}$ de Karel Capek, publicado em 1921, que esse medo se encontra expresso. A palavra robô, trazida para o léxico da ficção científica por Capek, vem do checo robota e significa trabalho duro ou forçado. Nesta obra, homens mecânicos, criados para trabalhar, tornam-se tão competentes que suplantam os criadores.

Também o filme Metropolis reflete esta conceção da máquina enquanto substituto da força de trabalho humana. Quando o cientista Rotwang apresenta o seu robô descreve-o como uma máquina à imagem do ser humano, mas que nunca se cansa ou comete erros. Oferece Maria como protótipo do trabalhador do futuro que tornará os humanos obsoletos. No entanto, o robô irá ser usado para enganar os trabalhadores, fazendo-se passar pela humana Maria sem que desconfiem da sua natureza mecânica. Acaba por seduzir os trabalhadores e enlouquecer o seu criador, revelando-se um agente destrutivo que os cidadãos da cidade acabam por queimar como se fosse uma bruxa, uma força maléfica que revela a sua estrutura metálica à medida que as chamas vão consumindo a superfície enganadoramente humana. Telotte $(i d$.$) considera que o robô de Metropolis é uma metáfora$ para o poder sedutor da tecnologia.

A ansiedade em relação à capacidade de a máquina superar o ser humano, seja pela eficácia produtiva ou pela inteligência, é um dos temas recorrentes da ficção científica, acentuada com a criação e disseminação do computador enquanto ferramenta de trabalho que obriga a competências técnicas específicas. Esta imposição da tecnologia sobre o humano insere-se dentro de uma tendência mais geral, sublinhada por vários autores, de aumento do poder das coisas sobre os outros. Roberts (2000) situa a origem deste processo na publicação de O Capital, de Karl Marx, que fez com que as coisas deixassem de ser apenas coisas e passassem a ser bens, impondo-se como desejo. A este fetichismo dos bens chamou-se reificação, que

23 Sigla para Rossum's Universal Robots. No entanto os robôs de R.U.R. são androides, máquinas antropomorfizadas, e não entidades meramente mecânicas. 
designa a ascensão das coisas ao estatuto de seres, garantindo-lhes poder sobre os humanos. As coisas, enquanto produtos da tecnologia, e a tecnologia ela própria enquanto bem, conduzem a reconfigurações do mundo e conceções de humano que obrigam imaginação a ir criando cenários para as múltiplas possibilidades de combinação entre as categorias em jogo.

\section{Computador}

A questão central nos filmes que abordam o computador é o perigo de criar máquinas inteligentes que possam facilmente suplantar os seus criadores, e a ansiedade gerada com a criação artificial de uma inteligência livre da interferência das sensações e dos sentimentos, de uma racionalidade pura e, por isso, superior, obrigando a deslocar para a emoção a essência do ser humano.

Os computadores são máquinas que incorporam as leis básicas do pensamento, funcionando de acordo com a lógica booleana que reduz todas as instruções a um conjunto de oposições binárias, evitando as ambiguidades das linguagem naturais. A sua imposição enquanto regulador do quotidiano nas esferas profissional e doméstica vai originar, a partir dos anos 1970 e até aos nossos dias, um conjunto cada vez maior de narrativas que abordam as crescentes ansiedades acerca do lugar do ser humano num mundo regulado pela informática.

De acordo com Scott Bukatman (1993:259), a ficção científica tem a função de dramatizar a sobreimposição da tecnologia. Nas suas palavras:

"O computador sozinho é narrado como uma extensão protésica, como uma substância aditiva, como um espaço para entrar, como uma intrusão nas estruturas genéticas humanas, e, finalmente, como substituto do humano num mundo pós-humano (o computador é justaposto ao humano, é sobreimposto ao humano e, no limite, supera o humano)."

O primeiro filme a tratar seriamente a questão da sobreimposição dos computadores em relação aos humanos e à criação de mundos pós-humanos é 2001: A Space Odyssey, de 1968, seguido de Colossus: The Forbidden Project 
(1970), The Demon Seed (1977) e Wargames (1983), que exploram o perigo de as mentes mecânicas poderem superar e substituir o ser humano.

HAL 9000 (designação construída a partir das letras que se seguem a I, B e M), o computador de 2001, é um dos computadores malévolos mais famosos da história do cinema. Mas o filme é complexo e a sua análise conduz a diversas interpretações. Traça a história da humanidade e da sua relação com a tecnologia. A odisseia espacial começa com o osso que é lançado ao ar e, numa elipse fílmica, se transforma num satélite orbital. A ideia que se pode inferir é a de que o humano cria a tecnologia, mas é ela que permite a evolução da humanidade, transformando a relação criador/criatura numa correlação dialética. Essa correlação conduz o humano e a máquina à infinitude do espaço. As máquinas são agentes de mediação entre a finitude humana e o infinito uma vez que os astronautas são fisicamente inaptos para manter uma relação direta com o cosmos envolvente, retratado por Kubrick como um organismo vivo.

O futuro parece perfeito e assético. A brancura da nave Orion contrasta com o negro do espaço e o azul da Terra, sublinhando a diferença entre o natural e o artificial e sugerindo a vitória da artificialidade. Os humanos assemelham-se também a máquinas e aparecem desligados, sem laços físicos ou psicológicos entre si. Com o evoluir do filme, as máquinas deixam de ser meras ferramentas. Desenvolvem consciência e transformam-se em outro. Vão parecendo cada vez mais grotescas e o confronto humano/máquina dá-se quando HAL entra em guerra com os astronautas, matando-os.

A partir deste ponto, o filme começa a tratar da vulnerabilidade da natureza orgânica humana e da humanidade da máquina, que se expressa na manifestação de sentimentos. Quando o astronauta Bowman desliga HAL 9000, este pede-lhe para não o matar porque tem medo de morrer, mostrando que nem a racionalidade mecânica está livre da emoção.

O último segmento dá uma nova chave de leitura ao filme. A viagem de Bowman no espaço transforma-se numa viagem no tempo. Os grandes planos dos olhos de Bowman sugerem a possibilidade de uma visão direta do Universo, já não mediada pelas janelas, vigias e ecrãs da tecnologia. Bowman vê sucessivas versões, cada vez mais velhas, de si, até ser mostrado o astronauta deitado na cama no fim da vida e uma névoa brilhante, contendo 
a imagem de um feto, que substitui a imagem anterior. O quarto dá lugar ao espaço aberto e volta a ver-se a lua e a Terra, e a criança envolta na névoa avança em direção ao espetador, deixando para ele a atribuição de significado final ao filme e a esperança de um novo estádio de evolução, sem esclarecer, no entanto, qual o papel da tecnologia nessa nova fase.

Já na década de 1980, em plena Guerra Fria, o filme Wargames (1983), de Harold Schneider, traduziu as ansiedades em relação à informatização dos vários domínios da realidade, do lazer aos palcos de guerra. A personagem principal é David (Matthew Broderick), um adolescente normal que escapa ao tédio da vida quotidiana usando o seu computador. Numa época anterior à difusão da internet, David acede a outros computadores através de uma linha telefónica e de um programa informático, alterando as sua notas escolares, conseguindo bilhetes para Paris e tentando roubar os planos para um novo jogo informático. Inadvertidamente, acede aos computadores do sistema de defesa e desencadeia um conjunto de procedimentos que terminariam numa guerra mundial, que o próprio David acaba por impedir.

O filme retrata dois dos medos da década de 1980: a ameaça nuclear e crescente dependência dos computadores na execução de tarefas cada vez mais importantes.

A ideia de que os computadores gerariam autoconsciência conduz a um conjunto de narrativas sobre o existencialismo maquínico, embora estas acabem por tender para uma antropomorfização, originando a figura do ciborgue, muito explorada ao longo dos anos de 1980. Na década seguinte torna-se frequente a noção de inteligência artificial, propondo seres informáticos, normalmente desincorporados e frequentemente malévolos, que possuem as características humanas sem as limitações impostas por um corpo, como é o caso de SID 6.7, o criminoso de Virtuosity (Brett Leonard, 1995) que resulta da combinação informática das personalidades de duzentos criminosos.

\section{Robôs}

As oposições humano/mecânico e natural/artificial, tal como são retratadas na ficção científica, não são necessariamente de oposição. Podem ser 
de complementaridade ou de submissão da máquina, apresentada como um poder controlado ao serviço da humanidade. Os robôs são normalmente as entidades que permitem esse tipo de relação. Ao contrário dos computadores convencionais, têm mobilidade, o que lhes dá maior antropomorfismo, mas mantêm um aspeto mecânico, não se colocando, por isso, a questão da determinação da fronteira entre os dois conceitos em oposição. São lugares do não humano, são criações, são máquinas programáveis que desempenham tarefas de um modo mais eficaz e dócil do que os humanos.

Isaac Asimov é um otimista em relação à tecnologia e, em 1941 enuncia as três leis da robótica, publicadas pela primeira vez nos contos Reason and Liar, integrados mais tarde na coletânea I, Robot. Estas leis servem para proteger o homem das suas criações e promovem a imagem do robô como bom escravo e não como ser malévolo. Assim, de acordo com a primeira lei, um robô não pode ferir um ser humano ou, por omissão, permitir que um ser humano sofra algum mal; a segunda diz que um robô deve obedecer às ordens que lhe sejam dadas por seres humanos, exceto nos casos em que tais ordens contrariem a primeira lei; e a terceira e última lei define que um robô deve proteger a sua própria existência desde que tal proteção não entre em conflito com a primeira e segunda leis.

Um dos robôs mais famosos do cinema é Robby, do filme Forbidden Planet, realizado por Fred M. Wilcox em 1956 e inspirado na última peça escrita por William Shakespeare, The Tempest. A ação de Forbidden Planet situa-se no século XxiII. Uma nave aterra em Altair IV, planeta habitado por Morbius, um cientista especializado em linguística, pela sua filha Altaira e por Robby, o robô, que desempenha o papel que na peça de Shakespeare cabe a Ariel. Morbius e Altaira são os últimos representantes dos Krell, habitantes do planeta que projetaram a sua mente coletiva, todo o conhecimento acumulado e valoração moral, numa máquina, Caliban. As forças representadas por Caliban correspondem no filme à materialização do id freudiano, lembrando que, na base da humanidade está a animalidade. Os outros habitantes de Altair IV haviam morrido porque no decurso do seu desenvolvimento alcançaram um ponto em que tornaram materiais os seus próprios medos, o que acontece também com Morbius quando um monstro começa a atacar a tripulação da nave, percebendo-se mais tarde 
que era o i $d$ do próprio Morbius, ativado pela máquina existente no planeta e alimentado pela inveja e ciúme que provocara a atenção dada aos viajantes pela sua filha.

Apesar de Robby, o robô dócil, se ter tornado um dos ícones do cinema de ficção científica, a sua importância no desenrolar da narrativa é reduzida, como é a dos robôs mais conhecidos da história do cinema: C3PO e R2D2, os robôs ao serviço das forças do bem dos filmes Star Wars. A sua relevância não vem dos seus atributos enquanto robôs, mas de se constituírem como contraponto cómico.

Também Gort, o memorável robô de The Day the Earth Stood Still, é uma entidade protetora, apesar do seu potencial destrutivo. São ambos extensões do homem de lata do The Wizard of Oz (Victor Fleming, 1939), são instrumentos, servos obedientes, máquinas equipadas para auxiliar o homem nas tarefas quotidianas e na exploração do espaço, mas ainda assim podem representar uma ameaça, na medida em que todos os escravos constituem uma ameaça para os senhores que os dominam.

Um dos filmes que joga com a ambivalência da figura do robô é $I$, Robot (Alex Proyas, 2004), baseado no conto de Asimov. A história decorre em Chicago no ano de 2035, num futuro em que os robôs se tornaram auxiliares comuns. Del Spooner (Will Smith) é um agente da Polícia de Chicago que se sente incomodado com a presença dos robôs na vida quotidiana, principalmente depois de um deles ter escolhido salvá-lo deixando morrer uma criança de doze anos, vítima do mesmo acidente.

Nesse acidente, Del Spooner perde o braço esquerdo e parte do tronco, que são substituídos por uma prótese robótica desenvolvida pelo Dr. Alfred Lanning (James Cromwell), um cientista da U.S. Robotics, cujo aparente suicídio é investigado pelo detetive. Spooner, que acha que o cientista foi assassinado por um robô chamado Sonny. Com a ajuda de Susan Calvin (Bridget Moynahan), uma psicóloga de robôs, procura resolver o mistério, descobrindo que os robôs do novo modelo NS-5 estão a destruir os exemplares de modelos anteriores, que ainda agem em obediência às leis da robótica.

Os NS-5 dão início a uma guerra entre humanos e robôs, e Spooner descobre que o responsável é VIKI (Virtual Interactive Kinetic Intelligence), o computador da U.S. Robotics, a que foram atribuídas as funções de 
programação dos NS-5 e o controlo das infraestruturas de Chicago. Apesar de ter sido programada de acordo com as leis da robótica, a sua inteligência artificial evoluiu, levando-a a concluir que, para proteger os humanos seria necessário sacrificar alguns. No final, VIKI é desativada com a ajuda de Sonny e a humanidade é salva dos robôs comandados pelo computador, restabelecendo o status quo original do robô enquanto auxiliar.

Os robôs, não sendo figuras de intersecção entre humano e máquina, são personagens da ficção científica que remontam a uma época em que essa dicotomia ainda tem fronteiras definidas. A máquina, podendo ter inteligência e corpo, não esconde a sua natureza, constituindo-se como instrumento, como extensão, refletindo o otimismo da robótica em libertar o humano das tarefas rotineiras e mecânicas.

É nas figuras do androide e do ciborgue, menos ancoradas à realidade e, por isso, passíveis de maior liberdade imaginativa, que as fronteiras se diluem e a hibridação se concretiza, permitindo refletir de modo mais fértil a relação entre o humano e a máquina.

\section{Máquinas Humanas}

Identificando a noção de eu como humano, as narrativas em que a máquina pode ser entendida como eu são aquelas em que a sua natureza mecânica não é imediatamente revelada, representando a fusão da tecnologia com a humanidade. Enquadram-se nessa classe os androides, que são máquinas desenhadas para parecerem humanos, e os ciborgues, que são humanos compostos por próteses mecânicas. Enquanto os computadores e os robôs se mantêm para lá da fronteira que separa as máquinas dos humanos, as máquinas que se assemelham ao humano ou o humano que se comporta mecanicamente dissolvem a dicotomia e revelam a fluidez das duas categorias. Apagando as distinções físicas entre humano e máquina, colocam-se as questões da identidade, da delimitação de fronteiras dos conceitos e até do próprio corpo enquanto lugar de crise.

A preocupação com essas entidades de fusão, máquinas que se assemelham a humanos ou humanos compostos de tecnologia, mais uma vez se 
pode relacionar com a questão da simulação, tal como é colocada por Baudrillard. Ela reflete as preocupações com a tecnologia, mas também nos interpela enquanto constructos, enquanto duplos humanos e enquanto criadores da tecnologia que nos imita e limita ou liberta.

\section{Androides}

Os androides são máquinas feitas para parecer humanos. Apresentam claras vantagens: não têm necessidades físicas nem se espera que tenham dramas psicológicos ou existenciais, não têm história nem destino e estão sujeitos a um controlo que os desobriga de decisões ou escolhas, características que lhes permitem superar os seus criadores em múltiplos aspetos, embora lhes falte o que poderemos designar por alma. No entanto esta noção pode ser problematizada.

Um dos primeiros filmes a abordar a questão de forma complexa foi The Creation of the Humanoids (Wesley Barry, 1962). O filme, de baixo orçamento, retrata um mundo após a Terceira Guerra Mundial, em que os humanos reconstroem as cidades com a ajuda de androides, os clickers. A justificação para dar forma humana às máquinas é o facto de os humanos acharem psicologicamente mais suportável trabalharem lado a lado com máquinas que se lhes assemelhem, mas estas vão abolindo a fronteira que as separa dos seus criadores e acabam por exigir os mesmos direitos, até porque, estando a humanidade está quase extinta e infértil, as máquinas vão aumentando através da duplicação dos corpos daqueles que morrem.

O protagonista é Kenneth (Don Megowan), um membro da ordem da carne e sangue que se opõe aos direitos das máquinas. Kenneth acaba por descobrir que ele próprio é um humanoide e submete-se a uma operação que lhe permite ascender à classe R100, categoria em que os androides se tornam férteis e capazes de procriar naturalmente, anulando uma das diferenças essenciais entre humanos e máquinas e afirmando a conciliação entre os dois conceitos.

Apesar da originalidade do argumento de The Creation of the Humanoids, é o filme Blade Runner que aborda de modo mais memorável a questão do estatuto ontológico de um ser criado pelo homem à sua semelhança, 
e onde situar a fronteira entre sujeito e objeto, humano e artificial, liberdade e determinismo.

Baseado na novela Do Androids Dream of Electric Sheep?, de Philip K. Dick, o filme de Ridley Scott cria um universo inspirado na banda desenhada de Moebius e no film noir, influência que se manifesta também nos dispositivos narrativos utilizados, como o voice over, na conceção das personagens, nomeadamente de Rick Deckard e de Rachel, e no guarda roupa escolhido.

Os androides no filme Blade Runner têm a designação de replicantes, réplicas construídas para serem mais humanas do que os humanos. Criados pela Tyrell Corporation para servir nas colónias exteriores, são declarados ilegais no planeta Terra, sob pena de morte imediata.

Os replicantes são humanos sintéticos, máquinas que respiram, sangram e morrem como os humanos e, por isso, impossíveis de identificar. Para os detetar existe um teste, a escala de Voight Kampff, que mede a empatia das respostas dadas a um conjunto de questões através das alterações da íris. O teste coloca a diferença entre humano e não humano na capacidade de sentir. Mas os replicantes são capazes de desenvolver emoções, por isso lhes é dado um limite de vida de quatro anos. São os blade runner, a força policial responsável por os perseguir e abater, quem se mostra incapaz de sentir empatia. É esta inversão que torna o filme inovador e que the garante a atualidade. A definição de máquina enquanto entidade lógica e racional por oposição ao humano emocional e empático, presente por exemplo em Ash, o androide do filme Alien realizado por Ridley Scott três anos antes de Blade Runner, é agora invertida. Quer Rick Deckard, o blade runner que tenta matar os replicantes revoltosos, quer Tyrell, o criador dos replicantes, se mostram menos humanos que as máquinas. Apenas Sebastian, o engenheiro precocemente envelhecido, é apresentado de modo claramente positivo, mas ainda assim preferindo a companhia das suas criações à dos outros humanos. O paralelismo entre Sebastian e Geppetto vem sublinhar a infantilidade dos replicantes, que têm uma esperança de vida de quatro anos. Combinam ingenuidade com implacabilidade e instituem-se como um id a ser confrontado com as regras e limites que lhes são impostos. O bom pai Geppetto/Sebastian é o contraponto de Tyrell, o deus sem compaixão, indiferente ao destino das suas criações. 
Blade Runner é também um filme sobre o sentido da vida e da morte, da finitude e da transcendência. A causa da revolta dos replicantes é a existência de um prazo de vida e o seu regresso à Terra dá-se para confrontar o seu criador e pedir mais tempo. No final do combate entre Deckard e Roy, a questão torna-se metafísica quando Roy, nos instantes que antecedem a sua morte, pergunta para onde irão todas as suas memórias, todos os momentos que se perderão no tempo, como lágrimas na chuva.

A fusão entre humano e máquina é a proposta do filme, explícita na relação entre Deckard e Rachel, uma replicante Nexus 6, o modelo a quem foram implantadas memórias para que não tivesse consciência da sua artificialidade. De acordo com Scott Bukatman (1997:81), a possibilidade de Deckard ser replicante, que se coloca principalmente na versão do realizador, é secundária. Serve, sobretudo, para obrigar o espetador a pensar sobre o seu próprio estatuto enquanto ser humano. Se Deckard fosse replicante, o filme perderia a moral, a dicotomização deixaria de existir e, consequentemente, a sua superação não poderia acontecer através da relação entre o humano Deckard e a androide Rachel.

O filme Artificial Intelligence (2001), de Steven Spielberg, retoma a questão da autoconsciência da artificialidade mecânica e da emoção enquanto traço definidor aplicável também às máquinas, numa narrativa centrada num androide criança que, à semelhança de Pinóquio, se julga menino. Spielberg mantém neste filme o tom predominantemente otimista em relação à alteridade, característico de filmes anteriores como E.T. e Close Encounters of the Third Kind.

Um androide que se apresenta de um modo diametralmente oposto dos replicantes de Blade Runner ou de Artificial Intelligence é o exterminador do filme The Terminator (Cameron, 1984). Retomando a dicotomia humano/ máquina, o filme mantém solidamente a oposição, não deixando dúvidas sobre a malevolência da tecnologia.

Tal como em Blade Runner, a ação de The Terminator passa-se em Los Angeles, num futuro relativamente próximo, onde duas figuras masculinas aparecem vindas do futuro. Uma delas é uma máquina envolvida em tecido orgânico, o T800, que tem como missão matar uma mulher, Sarah Connor, enquanto a outra personagem, Kyle Reese, é um humano que tem por 
objetivo evitar essa morte. Os dois seres foram enviados de um tempo em que as máquinas decidiram acabar com a raça humana. A guerra do futuro já não é entre humanos, mas entre humanos e máquinas, em que estas representam o inumano, o inimigo cujo traço distintivo é, mais uma vez, o excesso de racionalidade e a ausência de emoções, aliados à resistência e indestrutibilidade metálica que se contrapõem à fragilidade e vulnerabilidade do corpo humano. O exterminador não é uma criação humana, mas uma máquina de segunda geração, um androide criado pelas máquinas para se poder infiltrar entre os humanos sem ser detetado. O humano criou a máquina, que criou outra máquina para destruir o humano. Esta mediação criadora permite mais facilmente atribuir-lhe o estatuto de alien, de ser puramente mecânico que cumpre a sua missão sem empatia e emoção. O conceito proposto é o de tech noir ${ }^{24}$, de tecnologia malévola ou disfuncional, encontrando-se o filme cheio de dispositivos que não funcionam e, por isso, se tornam aliados do exterminador na sua missão destrutiva: Sarah não consegue comunicar com a polícia no momento em que está a ser perseguida porque o telefone está avariado ou porque as linhas estão ocupadas; não consegue avisar a colega do perigo porque esta tem o atendedor ligado e está de auscultadores; e o psiquiatra da polícia não vê o exterminador entrar na esquadra porque o seu beeper dispara nesse momento.

O filme termina com a destruição do exterminador e com a certeza de que o presente seguirá o seu curso até ao futuro original, mantendo o tom tecnofóbico para além da resolução do conflito. A sequela, lançada em 1992, reintroduz Arnold Schwarzenegger como exterminador, mas desta vez programado pelos humanos com o objetivo de proteger Sarah Connor e o seu filho John, futuro líder da resistência humana. Este espírito revisionista em relação à tecnologia está patente noutros filmes que denotam uma abordagem mais otimista em relação aos androides, dando às máquinas um papel de cuidador. No caso do exterminador, a função protetora da máquina é tornada explícita pelas palavras de Sarah Connor que, num mundo incerto, o elege como o melhor pai para o seu filho.

24 Tech Noir é o nome do bar noturno onde Sarah tenta esconder-se do exterminador e origina uma forma de adjetivação do estilo proposto pelo filme. 
No entanto, esta reconciliação humano/máquina é relativa, uma vez que o oponente continua a ser um androide, o T1000, um novo modelo criado pelas máquinas com o mesmo propósito de matar Sarah e John Connor, feito de metal líquido e capaz de assumir a forma daquilo em que toca, tornando obsoleto o T800. Esta tecnologia, aparentemente sem estrutura ou mecanismo, coloca o T1000 numa categoria muito mais alienígena, mais distante daquilo que é hipoteticamente concebível dentro do paradigma epistemológico existente. De acordo com Telotte (1995), este ciborgue representa uma nova espécie de ameaça tecnológica, um ser mecânico que não revelará a sua essência porque é apenas superfície, sem forma definida ou interior que possa indiciar a sua natureza tecnológica. Para o autor, o amorfismo ou polimorfismo do T1000 ilustram a dificuldade em perceber e avaliar o mundo para além das superfícies observáveis que são oferecidas pela tecnologia, conduzindo uma vez mais à noção de simulacro proposta por Baudrillard.

Constance Penley (1993) considera que o filme não avança com uma oposição entre homem e máquina, numa revisão da oposição romântica entre o orgânico e o mecânico, exatamente porque o exterminador é um híbrido, parte homem e parte máquina. Este argumento aplica-se sobretudo ao segundo filme, em que parece claro que o ser mecânico, à imagem dos androides de Blade Runner, é capaz de uma humanidade superior à dos humanos, embora sem a autoconsciência e revolta contra os criadores que esses manifestam, assemelhando-se, por isso, aos robôs da história do cinema que acatam de modo acrítico as leis da robótica de Asimov.

Poderá acrescentar-se que o Terminator 2 propõe que a tecnologia só se pode vencer com tecnologia, não a mais recente e avançada, mas a mais datada e dócil. Assimilada e humanizada a tecnologia do presente, a tecnologia do futuro continua a ser geradora de ansiedade.

\section{Ciborgue}

As oposições e dilemas referidos em relação aos androides colocam-se também relativamente aos organismos vivos que implantam partes mecânicas, 
uma outra forma de hibridação que funde as categorias humano/máquina e orgânico/artificial.

Donna Haraway (1991) reconhece o potencial da hibridação expresso na figura do ciborgue. Considera que os ciborgues, híbridos de máquinas e organismos, são criaturas que pertencem simultaneamente à realidade social e à ficção, e por isso podem considerar-se definidoras da ontologia pós-moderna. Segundo Haraway, o ciborgue não sonha com família, não se inscreve numa narrativa edipiana, não reconhece o jardim do Éden, não provém do barro e não volta a ser pó. É uma identidade fraturada, em que se dissolvem múltiplas antinomias, como corpo e alma, macho e fêmea, realidade e aparência, agente e recurso, construtor e constructo.

Defende que os humanos, enquanto dependentes da máquina e inscritos em discursos científicos formais, são ciborgues, intersetados pela ciência e tecnologia nos seus corpos e práticas sociais. Citando:

"Na medida em que nos conhecemos quer no discurso formal (por exemplo, biologia) quer na prática quotidiana (por exemplo, a economia doméstica no circuito integrado), descobrimo-nos ciborgues, híbridos, mosaicos, quimeras. Organismos biológicos transformaram-se em sistemas bióticos, dispositivos de comunicação como os outros. Não há separação fundamental, ontológica, no nosso conhecimento formal da máquina e organismo, do tecnológico e do orgânico 25

Um dos exemplos de intersecção radical entre o corpo humano e o mecanismo é apresentada no filme Robocop (1987), realizado por Paul Verhoeven. No filme, um polícia de Detroit (Peter Weller) é transformado em robô depois de um acidente terminal. O problema das fronteiras entre humano e mecânico, orgânico e artificial surge quando as memórias de Murphy, o polícia morto a partir do qual o ciborgue foi construído, começam a emergir. Em pouco tempo o filme centra-se nas questões inerentes à sua dupla identidade, colocando mais uma vez a emoção e a liberdade

25 A Manifesto for Cyborgs: Science, Technology and Social Feminism in the 1980s, in Redmond, 2004:158-181. 
como características associadas ao humano, por oposição ao determinismo dos mecanismos programados.

O filme é seguido de duas sequelas, uma de 1990, realizada por Irvin Kershner, e outra de 1993, realizada por Fred Dekker, nenhuma com o sucesso do primeiro filme, mas mantendo como conceitos centrais a humanidade da máquina e o pessimismo em relação às corporações capitalistas e às forças de governo.

Apesar do sucesso de Robocop, a conceção ciborgue na ficção científica está essencialmente associada ao movimento literário cyberpunk. Um dos poucos filmes cyberpunk, com um argumento do próprio William Gibson, é Johnny Mnemonic, realizado por Robert Longo e estreado em 1995. A ação passa-se em 2021 no planeta Terra, que é um sítio violento, negro e assustador, devastado por uma doença, a NAS (Nerve Alteration Syndrome), que resulta do excesso de exposição à tecnologia e provoca paralisia, tremuras e morte. Neste futuro, Mnemonic é um mensageiro que transporta informação no seu próprio cérebro, modificado de modo a receber, armazenar e descarregar dados em código informático.

Ao contrário dos filmes anteriores, a fusão humano/máquina dá-se ao nível do próprio cérebro. Já não se trata do perigo do computador se tornar superior ao humano, mas do humano se transformar numa extensão do computador através de implantes neurais, de se tornar um periférico, um mero dispositivo de armazenamento e transporte, a que se acede por ligação craniana (cranial jacking). Para se tornar eficaz, Mnemonic apaga as memórias de longo prazo, perdendo a noção de identidade que se pode obter por acumulação de experiências recordadas, tornando-se exemplo ilustrativo da desorientação e fragmentação identitária pós-moderna.

No decurso do filme, Mnemonic aceita um contrato que o obriga a carregar o dobro da informação que o implante neurológico permite, pondo em risco a sua vida. Além disso, é perseguido por terroristas e por uma corporação, ambos com o objetivo de aceder aos dados que o seu cérebro contém. Mnemonic acaba por conseguir sobreviver ao excesso de informação que carrega, derrotar os terroristas e a corporação que o perseguem, e ainda fornecer a cura para a NAS. 
Apesar do relativo fracasso do filme nas bilheteiras, não será de negligenciar a sua importância no facto de Keanu Reeves ter sido escolhido para o papel de Neo na distopia tecnofóbica da saga The Matrix, lançada quatro anos depois, onde os humanos já não são criadores, inimigos ou instrumentos das máquinas, mas suas criações, dando origem a uma nova categoria de tecnologia: a tecnologia como cosmos.

Um outro filme em que a questão humano/máquina foi equacionada é The Net (Irwin Winkler, 1995), embora a realidade retratada fosse tão temporalmente próxima e tecnologicamente plausível que se possa questionar a sua classificação enquanto filme de ficção científica. Angela Bennett (Sandra Bullock) é uma analista de sistemas cuja vida profissional e social é levada a cabo através do computador. Quando fica na posse de um disco com informação comprometedora, é perseguida e a sua identidade manipulada, passando a constar dos registos informáticos da polícia como uma criminosa procurada.

Como sublinha Cláudia Springer ${ }^{26}$, apesar de ser cauteloso em relação à tecnologia, o filme reforça também os medos em relação ao contacto direto entre humanos, uma vez que Angela se mostra muito mais vulnerável na sua existência no mundo real, o que permite estender a paranoia a todos os contextos de existência e não apenas ao mundo informatizado.

Total Recall (Paul Verhoeven, 1990), baseado no conto We Can Remember It For You Wholesale, de Philip K. Dick, também pode ser lido como uma alusão à fusão entre humano e tecnologia. O filme inicia com uma mulher a aproximar-se dos oficiais de imigração depois de uma aterragem em Marte. Responde a umas questões de rotina e tem uma convulsão, revelando que é apenas um disfarce robótico para o personagem Quaid, que tenta chegar a Marte sem ser detetado. Telotte (1995) considera que esta cena, com o humano escondido no interior do robô, resume o padrão da ficção científica das últimas décadas, mostrando robôs e ciborgues a revelarem corpo e espírito humano e a lembrarem-nos que o mesmo espírito habita em nós.

26 Psycho-Cybernetics in Films of the 1990s, in Kubn, 1999:203-218. 


\section{Máquina Cosmos}

Intersetando as categorias de tecnologia e espaço, pode ainda considerar-se a máquina, não como humano mas como a uma matriz a partir da qual o humano perceciona ou vivencia a realidade.

No final dos anos de 1990, com a crescente virtualização da realidade, são vários os filmes que se centram na capacidade tecnológica de mediar a experiência do mundo, como Strange Days (Kathryn Bigelow, 1995), eXistenZ (David Cronenberg, 1999), Thirteenth Floor (Josef Rusnak, 1999) e The Matrix, filmes que se enquadram na categoria que Springer (id.) designa por cybertbrillers.

A primeira noção estruturada da tecnologia enquanto matriz de existência real surge no livro Neuromancer, de William Gibson, publicado em 1984. Considerado um dos fundadores da corrente ciberpunk, Gibson apresenta um universo em que inteligências artificiais convivem com espíritos eletrónicos e pessoas equipadas com diversos implantes e próteses num espaço virtual, o ciberespaço. No Neuromancer a tecnologia sobrepõe-se ao humano e o artificial domina o natural. Os humanos submetem-se a transformações para melhorar as suas capacidades físicas, sensoriais e intelectuais, e podem ter uma existência na matriz que vai para além da vida física, tornando-se eletronicamente imortais. Os humanos, ainda que melhorados por ação da tecnologia, tornam-se meras células ou unidades de dados de um sistema informático global.

Johnny Mnemonic passa para ecrã o universo gibsoniano, a noção de humano enquanto habitante de uma realidade virtual, informatizada, enquanto extensão da tecnologia, mas é com a trilogia The Matrix que a tecnologia é assumida como matriz sustentadora da existência humana.

The Matrix é um texto que conjuga tecnofobia com mitologia, religião, filosofia e um estilo visual comic book. Esta fusão de estilos e conteúdos está patente de uma forma explícita na escolha dos nomes: Morpheus, deus do sono e dos sonhos, Trinity, uma alusão à tripla natureza do Deus cristão, Anderson, o filho do homem, Cypher, o traidor que deseja voltar a ser um número na matriz, Neo, o novo, anagrama de one, Logos, uma das naves humanas, e ainda Oracle, Architect e Keymaker, designações de programas 
informáticos permeáveis às duas realidades, a real e a matriz informática, que carregam uma simbologia mística.

A questão da dicotomia humano/máquina é levada ao extremo da tecnofobia. As máquinas dominam um futuro em que os humanos servem para gerar o calor e energia que as alimenta, com os seus corpos ligados a um sistema de recolha e transformação de energia e as suas mentes a um programa informático que lhes fornece a ilusão de existência num mundo real. O profundo desprezo das máquinas pelos humanos é expresso pelo agente Smith, que classifica a humanidade como um vírus, uma doença, o cancro do planeta, para o qual as máquinas são a cura.

As dicotomias presentes no filme, partindo do eixo humano/máquina, obrigam também à reflexão sobre as oposições coletivo/individual, emoção/ razão, realidade/virtualidade, aparência/essência e visão/compreensão, conduzindo o espetador através de uma dúvida cartesiana para lhe propor a solução platónica da existência de um outro nível de realidade. No entanto, tal como nos filmes anteriormente referidos, especialmente no Terminator 2, a tecnologia é combatida com tecnologia mais velha, menos eficaz, menos inteligente e sem autonomia, mas um auxiliar indispensável ao sucesso dos humanos na guerra contra as máquinas, o que permite reafirmar que, nas últimas duas décadas, o cinema de ficção científica explora não apenas os perigos da dependência do homem em relação aos instrumentos, mas, colateralmente, a impossibilidade de estabelecer oposições definitivas entre os dois termos da dicotomia.

Um outro tipo de narrativas que trata a tecnologia como cosmos são as que se centram na nave. Como refere Vivian Sobchack ${ }^{27}$, a nave, sendo um dos ícones da ficção científica, não tem um sentido unívoco e consistente. Além de mostrar que a ação se passa num tempo futuro ou num espaço distante, o significado que a nave assume no filme é variável.

Enquanto dispositivo tecnológico, as naves são muito importantes. Têm o estatuto de quase personagem uma vez que representam as possibilidades tecnológicas imaginadas, enquanto extensão instrumental do homem. Um

27 Images of Wonder: The Look of Science Fiction in Redmond, 2004:5 
dos primeiros filmes de ficção científica enquanto género cinematográfico autónomo, Destination Moon (1950), é uma narrativa centrada na construção de um foguetão que permite levar os americanos à lua. Neste filme, a nave é o resultado visível da tecnologia encarada de forma positiva, originando uma narrativa tecnofílica. Produzido por George Pal, baseia-se na novela Rocket Ship Galileo, de Robert Heinlein, publicada em 1947, e inaugura um ciclo de filmes que se prolongará até à década seguinte. No livro, um cientista e três estudantes de liceu constroem um foguetão atómico e fazem o que julgam ser a primeira viagem à lua. Uma vez lá, descobrem nazis, uma base de foguetões e planos para um ataque com mísseis atómicos. $\mathrm{Na}$ adaptação cinematográfica de Pal, em conformidade com o novo contexto geopolítico, a ameaça já não são os nazis mas a União Soviética, e os três rapazes da novela dão lugar ao general Thayer, ao industrial Jim Barnes e a Joe Sweeney, um técnico de rádio, que ilustram as vantagens da aliança institucional entre o poder militar, a indústria e a técnica.

A necessidade de verosimilhança e a importância desta narrativa no contexto de corrida espacial manifestam-se nas cenas de construção do foguetão, assumidas quase como documentário. Vários cientistas e engenheiros visitaram o set durante as filmagens, ajudando nos cálculos e estatísticas de modo a dar mais autenticidade, o que resultou num Óscar para Pal pelos efeitos especiais.

Depois de construído, e contrariando ordens superiores, o foguetão é lançado com os quatro homens a bordo. No seu interior, os homens são empurrados contra as cadeiras devido à aceleração e experimentam a ausência de gravidade. Para filmar isto, Pal criou uma cabina suspensa que podia ser virada para qualquer ângulo, com painéis que podiam ser removidos para que as câmaras pudessem filmar de qualquer posição e cabos que prendiam os atores.

Apesar dos problemas de descolagem, a nave parte de regresso à Terra com toda a tripulação e, à medida que o planeta vai crescendo no ecrã pode ler-se "Isto é o fim", seguido das palavras "do princípio", frases premonitórias não apenas do sucesso das viagens à lua, mas principalmente do sucesso da ficção científica enquanto género cinematográfico, uma vez que o sucesso do filme serve de inspiração para as produções que se seguem. 
As naves acabaram por se tornar mais do que máquinas, constituindo-se como um locus que exprime personalidade e caráter, representando também a fusão entre o humano e o tecnológico. Ela aparece enquanto cosmos, habitat da espécie humana na sua exploração do Universo, e a Enterprise é, provavelmente, o paradigma da nave da ficção científica no seu modo visual.

Quer a Enterprise de Star Trek, quer a Discovery de 2001, quer ainda a Nostromo de Alien são espaços tecnológicos contidos, artificiais, onde decorrem as relações humanas no seu modo futuro. São simultaneamente contentores do humano e dispositivos que permitem a conquista de outros espaços e o encontro com o desconhecido, expondo, por vezes, os passageiros ao terror que pode vir do exterior, como acontece no filme Alien O oitavo passageiro. Neste casos a nave transforma-se em prisão, ganha uma dimensão claustrofóbica e assemelha-se aos espaços dramáticos do terror, às mansões assombradas com túneis e corredores escuros onde o perigo se esconde, num espaço e tempo próprios, desligados do real empírico.

\section{Tempo e Espaço}

Espaço e tempo são coordenadas básicas de qualquer representação do mundo e da própria identidade. Kant considera que estas categorias são condição a priori de qualquer captação sensorial do mundo, estabelecendo uma hierarquia entre elas. O espaço é condição de experiência de todos os fenómenos externos, mas o tempo é a condição da experiência em geral, ou seja, dos fenómenos externos e internos. Uma vez que toda a exterioridade tem de se transformar numa interioridade, o tempo ganha primazia sobre o espaço.

De acordo com a tradição filosófica kantiana, tempo e espaço não são propriedades das coisas ou realidades independentes, mas formas unificadoras impostas pelo sujeito na sua experiência do mundo. No entanto, este idealismo transcendental pressupõe também que o sujeito nunca possa ter conhecimento da realidade externa tal como ela é, numenicamente, uma vez que a capta sempre enquadrada no espaço e no tempo, categorias que são suas e não da própria realidade. 
Comprovando a sua importância na perceção do mundo, a ficção científica tem manipulado tempo e espaço em jogos de deslocação que obrigam a um reposicionamento do espetador e a uma reflexão sobre a relatividade da sua cosmovisão. Também para a ficção científica o tempo é a categoria mais importante do par, uma vez que a distinção entre tempo e espaço serve essencialmente para sublinhar o modo temporal da ficção científica: um tempo não presente traduz-se na configuração ou reconfiguração do espaço, mas um espaço não familiar nem sempre obriga a um posicionamento temporal relevante para a narrativa.

A alteridade espacio-temporal, característica da ficção científica, implica a deslocação para um horizonte alternativo à realidade do espetador, um mundo outro criado por manipulação do espaço e tempo, que remete para a noção clássica de utopia.

Conforme foi referido, o modo temporal da ficção científica não é a utopia, mas a outopia, um lugar outro situado em lugar nenhum. O mesmo se pode aplicar ao tempo. As narrativas da ficção científica são oucrónicas, decorrem num tempo outro, muitas vezes em aderência ao passado e futuro que a linha temporal nos impõe, mas que é 'tempo nenhum', um passado, presente ou futuro concebido à margem da história ou para além dela, como acontece nas narrativas de deslocação temporal.

\section{Tempo}

A deslocação temporal é um dispositivo frequente na ficção científica, seja para o passado (a long time ago in a galaxy far away), seja para o futuro próximo ou distante, podendo por isso afirmar-se que o horizonte da ficção científica é omnitemporal, feito de todos os tempos possíveis. No entanto, o posicionamento temporal mais frequente na ficção científica recente é o futuro, seja próximo ou distante. Nos filmes de ficção científica da década de 1950 esta distância temporal era curta ou inexistente. Os contextos dos filmes de ficção científica eram presentes possíveis, sem que as marcas temporais se expressassem em termos de reconfiguração geográfica, social, política ou arquitetónica em relação ao mundo real. Ilustrativos são os filmes 
como The Thing (1951), Destination Moon (1950), When Worlds Collide (1951), War of the Worlds (1953) ou The Invasion of the Body Snatchers (1956).

O filme 2001: A Space Odyssey (1968) pode considerar-se o primeiro a criar uma dilatação temporal consistente no cinema de ficção científica. As narrativas das décadas de 1970 e, principalmente de 1980, passam a ser essencialmente histórias de futuro.

A tarefa de construir imaginativamente o futuro é a que melhor permite a extrapolação, a formação de hipóteses de futuro partindo das observações empíricas do mundo atual. No entanto, o futuro extrapolado não poderá ser demasiado longínquo, caso contrário a quantidade de variáveis envolvidas será tão grande e imprevisível que se torna inimaginável e o futuro pode inverter a direção, colocando a narrativa num modo nostálgico, recorrendo a variações de épocas históricas anteriores, que reduzem a função cognitiva envolvida na projeção epistemológica do presente.

Os futuros do cinema de ficção científica das décadas de 1980 e 1990 situaram-se predominantemente nos primeiros anos do milénio que se avizinhava, explorando os desenvolvimentos verosímeis que podiam derivar do presente empírico. A ação de Blade Runner (1982), por exemplo, situa-se em 2019, um futuro a quase quarenta anos de distância em relação ao lançamento do filme, tempo suficiente para extrapolar do mundo real as possibilidades de colonização do espaço, de criação de androides, de quase extinção de vida animal, de crescimento das cidades, de afirmação do multiculturalismo, de expansão do capitalismo, de dissolução dos laços de inter-relação humana e de atomização e fragmentação identitárias. Com algumas variações na dosagem dos ingredientes, este é o cenário da maior parte dos filmes das décadas, acrescentando-se com frequência a sugestão de apocalipse, recente ou eminente, provocado por guerras (Terminator), por acidentes biológicos (Resident Evil) ou catástrofes naturais (Armageddon).

\section{Viagens no Tempo}

Quando a deslocação na linha do tempo, seja em direção ao futuro ou ao passado, é alcançada através de um dispositivo tecnológico, a narrativa inse- 
re-se na subcategoria das viagens do tempo, de que é exemplo paradigmático a novela de H. G. Wells, The Time Machine (1895), que origina adaptações cinematográficas em 1960 (George Pal) e em 2002 (Simon Welles).

The Time Machine representa a forma mais simples da narrativa de viagem temporal. A existência de uma máquina que permite a viagem serve para ilustrar que através da ciência o homem pode dominar o tempo e encontrar-se com a humanidade nos seus vários estádios de evolução.

A questão da possibilidade de viajar no tempo obriga também a refletir sobre as possibilidades de intervenção no curso dos eventos passados, alterando-os e criando desse modo novas possibilidades de presente. Uma dos primeiras narrativas a abordar o que ficou conhecido como efeito borboleta $^{28}$ foi o conto $A$ Sound of Thunder, escrito por Ray Bradbury em 1952. Em 2005 foi feita uma adaptação cinematográfica com o mesmo nome, realizada por Peter Hyams, embora o princípio da teoria do caos tenha sido aproveitado para outros filmes, com uma narrativa semelhante à de $A$ Sound of Thunder, assumindo que a existência de uma mera de uma borboleta terá efeitos profundos nos acontecimentos históricos subsequentes, como acontece em The Butterfly Effect, filme de 2004 com realização e argumento de Eric Bress e J. Mackye Gruber, com sequelas em 2006 (realização de John R. Leonetti) e 2009 (realização de Seth Grossman). Todos os filmes assumem que as pequenas alterações que possam decorrer de uma viagem temporal ao passado provocarão consequências imprevisíveis no mundo presente tal como é conhecido. Nestas narrativas não é tanto a tarefa extrapolativa ou reflexiva envolvida que move a história, mas antes uma divulgação e exploração do princípio científico que está na sua base, adaptado às exigências narrativas cinematográficas de ação e romance.

\section{Paradoxos Temporais}

A exploração da possibilidade de viagem temporal para além do efeito borboleta origina os paradoxos temporais (time loops), uma relação circular

\footnotetext{
${ }^{28}$ Expressão criada por Edward Norton Lorenz, matemático e meteorologista norte-americano que desenvolve estudos na teoria do Caos.
} 
entre causa e efeito que viola os princípios da lógica. Os time loops afirmam simultaneamente a liberdade e o determinismo e quebram a visualização do tempo como uma linha contínua.

Os filmes Terminator são narrativas exemplares de time looping. Em 2029, um ciborgue assassino é mandado para 1984 para matar Sarah Connor, a futura mãe do líder da resistência, acabando deste modo uma guerra que não viria a ter início se a missão fosse bem sucedida. Mas John Connor, o líder da resistência humana, envia também um emissário do futuro para evitar o assassinato da sua mãe, garantindo assim o seu próprio nascimento. Para fazer essa viagem escolhe Kyle Reese, um dos membros da resistência, que se apaixona por Sarah através da fotografia que John lhe dá. "Atravessei o tempo por ti" é uma das frases que Kyle diz a Sarah pouco antes de fazerem amor e conceberem John. Kyle morre pouco depois e Sarah destrói o exterminador e parte para as montanhas para dar à luz o seu filho e esperar pelo holocausto. O filme termina na fronteira mexicana, com um jovem a tirar uma fotografia a Sarah, aquela que John dará a Kyle para este poder identificar a sua mãe no futuro (que é passado). Nesta narrativa, os acontecimentos posteriores são causados pelos anteriores e estes pelos posteriores. Se John não tivesse enviado Kyle nunca poderia teria nascido. Como nasceu, a sucessão de eventos que lhe deu origem terá de ter acontecido antes. Outro paradoxo é que as competências de combate que John possui no futuro foram ensinadas pela mãe, que por sua vez as aprendeu de Kyle, que por sua vez as aprendeu com John.

O segundo filme da série acrescenta mais um paradoxo uma vez que a origem do mecanismo de defesa que desencadeia a autonomização das máquinas em relação aos humanos está no chip encontrado nos fragmentos do exterminador que veio do futuro no primeiro filme. Se a guerra não tivesse acontecido, a liderança de John Connor não seria necessária, logo não haveria necessidade de prevenir o seu nascimento, logo não haveria necessidade de enviar Reese para proteger Sarah, logo John Connor não poderia nascer, logo o exterminador não seria enviado e não traria a tecnologia que daria origem à guerra, transformando-se o time loop numa espiral.

Poderemos interrogar-nos porque é que, sendo possível viajar no tempo, não foi enviado um emissário para o momento em que as máquinas inte- 
ligentes são criadas, evitando esse acontecimento e todos os que se the seguem. Embora essa seja uma das linhas de ação de Terminator 2, destruir o mecanismo para que não se dê o apocalipse, continuaria a ser possível o envio para um tempo anterior, evitando toda a sequência de acontecimentos que conduz à guerra com as máquinas.

Outro exemplo de time looping é Back to the Future (1985, 1989 e 1990), produzido por Steven Spielberg e realizado por Robert Zemeckis. O filme combina vários ingredientes: humor, ação, romance, efeitos especiais e nostalgia pelos anos de 1950, atraindo audiência de todas as idades e transformando a viagem no tempo numa comédia. O protagonista, Marty McFly (Michael J. Fox), é um adolescente frustrado, com um pai fracassado e uma mãe insatisfeita, que passa a maior parte do seu tempo com a sua namorada Jennifer e com Doc Brown, um excêntrico cientista que inventa uma máquina do tempo. Marty recua trinta anos no tempo e interrompe o primeiro encontro entre os seus pais, colocando em risco a futura relação e, consequentemente, o seu próprio nascimento. Para evitar desaparecer, tem de convencer os seus pais que foram feitos um para o outro. Sendo uma comédia com ingredientes edipianos, Marty acaba por conseguir que o pai se afirme contra o poder de Biff, o rufia que o atormenta desde a juventude, que a mãe se apaixone pelo pai e que ambos se transformem em pessoas satisfeitas e equilibradas, permitindo que o presente se altere e os valores familiares tradicionais sejam alcançados, revelando uma matriz conservadora pouco conforme com a tradição da ficção científica.

\section{Histórias alternativas}

Outro tipo de narrativa centrada no tempo é a história alternativa, em que o tempo não é concebido como uma linha única mas como um número infinito de linhas, cada uma representando uma realidade, estabelecendo a possibilidade de viagens não apenas para o passado ou futuro, mas paralelas, num movimento de divisão temporal (time split).

Este tipo de narrativas é mais frequente na literatura do que do cinema. Por exemplo, Bring the Jubilee, escrito em 1955 por Ward Moore, retrata 
uma América em que o sul vence a guerra civil. A história acaba com a invenção de uma máquina do tempo em que o protagonista (um historiador) viaja para observar a batalha de Gettysburg, provocando com a sua presença uma alteração no resultado da batalha que faz com que a história siga o curso que conhecemos. Estas ficções têm interesse por sublinharem a contingência, jogando mais uma vez com a oposição entre liberdade e determinismo histórico. Em termos cinematográficos, um exemplo é It Happened Here (1966), um filme britânico escrito e realizado por Kevin Brownlow e Andrew Mollo, que apresenta de um modo documentário uma invasão de Inglaterra pelos nazis.

Quando a história alternativa se centra num único indivíduo, explorando as linhas temporais paralelas, dá origem a filmes como Sliding Doors (Peter Howitt, 1998) ou The Groundhog Day (Harold Ramis, 1993), este último vagamente baseado na novela Replay de Ken Grimwood, publicada em 1986, em que o protagonista, Jeff Winston, morre aos quarenta e três anos com um ataque cardíaco e acorda aos dezoito anos com as memórias dos vinte e cinco anos seguintes. Faz muitas escolhas diferentes, torna-se mais rico e satisfeito e morre novamente aos quarenta e três para acordar aos dezoito com as memórias de duas vidas. A vida dele continua em replay até experimentar todas as linhas possíveis, mesmo uma que acaba em suicídio. Em The Groundhog Day, um meteorologista de uma estação televisiva local, Phil Connors (Bill Murray), é enviado para cobrir as comemorações do feriado do Dia da Marmota em Punxsutawney, Pennsylvania. O mau tempo obriga-o a ficar mais uma noite, acordando no dia seguinte para perceber que se encontra preso no Dia da Marmota, vivendo-o de múltiplas maneiras depois de ter percebido que as suas ações não têm consequências porque não existe futuro para além daquele dia.

As viagens no tempo apresentadas no cinema de ficção científica recente não se dirigiram a um passado idealizado, mas tenderam a alterar as condições do presente, refletindo, não apenas a insatisfação com o mundo zero, mas a vontade de retornar a um passado que permita a sua correção.

Ao longo da década de 1990, com a aproximação do final do milénio, os futuros foram-se tornando mais curtos. A ação de grande parte dos filmes 
de ficção científica centrou-se num tempo muito próximo, como aconteceu com Strange Days (1995), cuja ação decorre na passagem de ano para o novo milénio, Twelve Monkeys (1995), The Net (1995), Armageddon (1997), eXistenZ (1999) ou mesmo a saga The Matrix.

Na primeira década do século XXI a tendência de encurtar o futuro mantém-se, voltando a tratar-se, em muitos casos, de um presente possível, como em The Island (2005), Godsend (2004), Signs (2002) ou War of the Worlds (2005).

Nestas duas décadas, apesar de muita da ficção científica se situar ainda num futuro (Alien: Resurrection e Star Trek) ou passado (Star Wars) distantes, a tendência de encurtar a distância temporal diminui a tarefa extrapolativa. Quanto mais próximo o futuro, maior a plausibilidade e menor a previsibilidade, garantindo-se assim uma maior a identificação do espetador com o contexto. No entanto, os filmes referidos promovem outras formas de estranheza e novas chaves de leitura e descodificação do texto e do mundo, envolvendo tempos e espaços alternativos que se traduzem em formas de perceção alternativas.

\section{Espaço}

A conquista do espaço pareceu, durante quase um século, um dos últimos grandes desafios físicos da humanidade. A justificação para a exploração espacial era baseada nos impulsos humanos básicos de conquista territorial ou então proposta como um dos grandes desafios políticos da Guerra Fria. Além das vantagens práticas que a conquista de outros mundos oferecia, nomeadamente a possibilidade de substituir um planeta cujos recursos naturais são limitados, a viagem espacial pode explicar-se também por uma atração quase religiosa: a conquista do céu, a afirmação do poder do homem, a sua expansão para além dos limites físicos a que estava circunscrito. Desse modo, é natural que o espaço se tenha tornado um dos aspetos essenciais da visão de mundo científica e da ficção científica enquanto capacidade de lhe dar uma forma imaginada.

É também o espaço que permite o encontro com a diferença. O radicalmente outro, a diferença absoluta já não se encontra no planeta Terra, em 
que a fauna e flora se encontram catalogadas e a alteridade cultural académica e cientificamente compreendida e acomodada a um leque de atitudes que vai do etnocentrismo ao interculturalismo.

No entanto, o fim da Guerra Fria e a dissolução das condições políticas e sociais que alimentaram a conquista espacial, a explosão do Challenger, a afirmação da diferença interna na forma de movimentos sociais, políticos e culturais e a consciência dos problemas ecológicos, podem apontar-se como razões que obrigam a uma deslocação da atenção e preocupações políticas e culturais novamente para o planeta Terra, mostrando que este não está tão controlado e dominado como a racionalidade científica instrumental faria antecipar. O cinema de ficção científica dos anos 1980 e, principalmente, dos anos 1990 e 2000 é sintomático desta tendência, recentrando a ação na Terra depois de décadas de filmes e séries televisivas situadas na fronteira final do espaço.

\section{Utopias e dissonâncias cognitivas}

A primeira forma de conjugar tempo e espaço é na figura da utopia que, como já referimos, é entendida como uma eutopia que implica uma eucronia, constituindo-se como um um espaço tempo ideal.

Segundo Penley (1993), a entropia da imaginação utópica é a de que conseguimos imaginar o futuro, mas não conseguimos conceber o tipo de estratégia política coletiva que é necessária para assegurar esse futuro. No entanto, o problema da utopia não é tanto o modo de chegar a um estado de perfeição, mas como transformar em narrativa o que acontece depois, uma vez que a utopia é estática e a imaginação narrativa envolve o conflito e a sua superação. A imaginação do futuro deverá implicar a ultrapassagem de limites e a conquista de fronteiras, mas qualquer transformação na utopia resultará num declínio, logo a inovação imaginativa não poderá existir na utopia. A este respeito, Wells, em A Modern Utopia, distingue entre utopias estáticas e cinéticas, sendo as primeiras um estado de perfeição absoluto e as segundas apenas um estado melhor do que o mundo empírico do autor. São estas, e não as primeiras, que 
interessam à ficção científica. Como refere Captain Kirk no final do episódio This Side of Paradise, da série Star Trek, "talvez não tenhamos sido feitos para o paraíso... talvez tenhamos sido feitos para lutar pelo nosso caminho".

Pode considerar-se que a dicotomia central que a utopia coloca em jogo é a oposição filosófica entre realismo e idealismo, entre as condições reais e as condições ideais de existência. De acordo com Darko Suvin (1979), o campo temático da utopia é a comunidade imaginada, na qual as relações humanas estão organizadas de modo mais perfeito do que na comunidade real de que o autor parte para, num movimento de travelling, mostrar as diferenças entre o real e o ideal. Suvin sublinha que a utopia é uma construção literária que oferece um outro mundo imanente ao mundo humano. Para o autor, numa utopia devem encontrar-se uma alternativa radicalmente diferente para a condição sociopolítica, uma comunidade imaginada na qual as relações estão organizadas de modo mais perfeito do que na comunidade do autor, a construção ficcional de tal condição, localização ou comunidade, e aquilo que a distingue dos outros projetos utópicos. Sendo um discurso sobre uma comunidade alternativa, deve ser um locus contido (vale, ilha, planeta), deve mostrar a articulação entre as várias organizações que constituem o locus (religião, aparelho militar, governo, economia) e o sistema hierárquico formal (há utopias autoritárias e de libertação, com classes e sem classes, mas não há utopias sem organização), e deve possuir uma estratégia dramática que permita o conflito com as expectativas do leitor. Embora formalmente fechada, a utopia deve ser tematicamente aberta uma vez que aponta para o topos do leitor, permitindo o estranhamento cognitivo, ou seja, constitui-se como uma grelha que permite uma leitura alternativa do mundo.

Suvin (id:49) propõe uma definição:

"Utopia é a construção verbal de uma comunidade quase humana particular onde as instituições sociopolíticas, normas e relações individuais estão organizadas de acordo com um princípio mais perfeito do que na comunidade do autor, construção baseada no estranhamento que advém de uma hipótese histórica alternativa." 
É o enraizamento no campo das possibilidades históricas que distingue a utopia dos outros géneros literários que utilizam o estranhamento cognitivo como dispositivo. Ao contrário do mito, não tenta identificar a essência eterna dos fenómenos, mas a sua contextualização material, histórica, tendo por isso uma validade que depende do contexto de partida da narrativa. Também não propõe uma realidade com um estatuto ontológico diferente (seja superior ou inferior), mas com estatuto ontológico igual ao do mundo empírico do criador e do leitor: institui-se como uma realidade alternativa, que possui um espaço próprio e um tempo histórico diferente, e, por isso, diferentes normas e relações. Permite um deslocamento da realidade e obriga a um movimento de oscilação entre o mundo empírico do leitor e o mundo da narrativa, de modo a que este possa dar significado aos acontecimentos descritos, e da narrativa para o mundo empírico do leitor, de forma a permitir-lhe um novo ângulo de interpretação do real, cumprindo uma função cognitiva e reflexiva.

Edward James ${ }^{29}$ considera que os acontecimentos do século xx marcaram o fim do idealismo e a sua substituição por cinismo e pessimismo. Mas propõe que a utopia não morreu, apenas mudou de forma em relação à utopia clássica. Se no final do século XIX muitas das utopias propostas apresentavam variações do socialismo, propondo uma organização comunitária em que dinheiro e a propriedade privada não existem e razão e a boa vontade se mostram suficientes para manter a paz e a harmonia, no século xx esta conceção utópica foi atacada em duas frentes: por um lado, pelos que argumentavam que, na realidade, muitas dessas utopias se tornariam distopias, sociedades oprimidas pela tirania de manter a perfeição do sistema a custo da liberdade individual ou pela dificuldade de impedir as elites de impor a sua autoridade sobre a maioria, por outro lado, por aqueles que as consideraram impraticáveis. Daí que a ficção científica, pela necessidade de aventura e expansão contínua de horizontes sociais e tecnológicos, tenha afirmado um projeto antitético com a utopia clássica, para o qual James propõe a designação de utopismo tecnológico. Este autor considera que, nos anos setenta, se assiste a um revivalismo da (e)utopia

29 Utopias and Anti-Utopias, in James e Mendlesohn 2003:219-229. 
como resultado dos movimentos feministas, ecologistas, raciais e sexuais que se iniciam na década de sessenta. As narrativas derivadas ou influenciadas por estes movimentos não se limitam a criticar a realidade fornecendo um mundo alternativo, mas criticam o mundo imaginado também, ficando por isso conhecidas como utopias crítica, capazes de combinar a imaginação emancipadora com a reflexividade pós-moderna, desafiando os limites formais e políticos da utopia tradicional.

Nos anos 1980, esta tendência utópica chega ao fim. A história recente da ficção científica, principalmente no seu modo cinematográfico, propõe predominantemente visões distópicas, mostrando, extrapolativamente, como o ser humano poderá chegar a condições piores de existência. Segundo Raffaella Baccolini e Tom Moylan (2003) isso deve-se, em larga medida, à reestruturação económica, às políticas de direita, a um meio cultural crescentemente fundamentalista, à mercantilização e à fragmentação dos projetos utópicos da década de 1960 em questões de afirmações identitárias circunscritas.

O texto distópico, ao contrário do utópico que começa com uma visita ao mundo ideal, não implica qualquer viagem ou dispositivo onírico. Normalmente o personagem e o espetador já estão no mundo distópico. No entanto, a contranarrativa desenvolve-se à medida que o estado geral dos habitantes do mundo distópico passa de contentamento ou resignação para alienação ou resistência. O facto de poder conter esperança, de não se limitar a aniquilar os indivíduos como acontece em 1984 ou Brave New World, será suficiente para que Baccolini e Moylan (id.) considerem tratar-se de distopia crítica. A distopia crítica é aquela que abre um espaço de resistência para os sujeitos, que permite a afirmação de vozes dissonantes que combatem e podem vencer a opressão, o que acontece na quase totalidade dos filmes de ficção científica, que acabam normalmente com a vitória dos heróis e o estabelecimento ou restabelecimento de condições mais favoráveis à existência humana.

Na década de noventa as narrativas do cinema de ficção científica afirmam cada vez mais um espaço e tempo alternativos, deslocando o núcleo de reflexão para a questão das fronteiras, já não entre real e ideal, mas entre real e virtual. O binómio realidade/virtualidade torna-se central, sublinhando o caráter ilusório da realidade, dando contornos às teorias de 
Baudrillard, para quem o simulacro e a simulação permitem a construção de sentido sem referência à realidade. A cópia não se limita a deixar de estar ligada ao original mas precede-o Para o autor, a vida pós-moderna é dominada pelas aparências, superfícies que constantemente conspiram para combater o sentido da realidade, dividindo o próprio indivíduo, que corre o risco de obliteração pela saturação de mensagens e por passar a relacionar-se virtualmente com os outros.

Bukatman (1993) considera que Baudrillard é, ele próprio, um escritor ciborgue, que impõe um tecnologismo sobre a familiaridade daquilo que continuamos a chamar experiência direta, cujo discurso é, ele próprio, uma ficção científica que, repetida e obsessivamente, narra a perda da narração. Para Bukatman, parte da responsabilidade deste abalo das fronteiras tradicionais da realidade deve-se ao novo espaço tecnológico, que exige uma nova cognição. Na transição do milénio, o mundo virtual torna-se real, muitas vezes mais familiar e mais satisfatório do que a realidade física. A realidade move-se para um não-espaço eletrónico onde tudo se transforma em dados. É um espaço descentrado que existe paralelamente à geografia espacial, topográfica da realidade, aquilo que Scott Bukatman (id.) designa por para-espaço cibernético (cibernetic paraspace), onde se corporiza a descorporização pós-moderna.

No cinema de ficção científica, esta desorientação alimenta narrativas de dissonância cognitiva em que se questiona a experiência natural do tempo e do espaço e os limites da perceção. Tempo e espaço deixam de ser categorias que o sujeito aplica à sua experiência interna e externa, mas passam a ser construções tecnológicas ou tecnologicamente mediadas, criadas para libertar a experiência humana dos limites físicos ou mentais que a experiência direta do mundo físico impõe.

Como já foi referido, em filmes como Dark City (1998), The Matrix (1999) ou The Thirteenth Floor (1999), há uma realidade consensual que se dissolve e prova ser uma ilusão, um mundo de sombras como a caverna platónica, onde espreita um génio maligno cartesiano. Como sublinha Kaveney (2005:65), "aceite a possibilidade de entrar numa realidade que construímos e interagir com seres que acreditam eles próprios ser reais, o estatuto do nosso próprio mundo fica abalado". 
No filme Dark City, baseado no argumento do próprio Alex Proyas, a ação passa-se numa cidade onde não há sol e em que John Murdoch acorda para descobrir que não tem memórias e é suspeito de vários homicídios. Com o correr da narrativa acaba por perceber que os habitantes da cidade foram raptados por uma espécie alienígena chamada strangers (que significa simultaneamente estranhos e estrangeiros) e vivem numa estação espacial construída para parecer um centro urbano terrestre. Através da força mental coletiva, os strangers reconstroem a cidade continuamente e reprogramam os humanos, apagando as memórias anteriores e atribuindo-lhes novas identidades com o objetivo de perceber se os humanos têm alguma coisa de imaterial, uma alma, ou se são simplesmente programáveis, e deste modo perceberem se há ou não uma identidade individual independente das condições reais de existência.

Dark City é uma história de procura da verdade, levada a cabo por Murdoch e por Bumstead, o detetive interpretado por William Hurt, embora este o faça de modo mais limitado uma vez que procura resolver o mistério dos crimes ocorridos na cidade, enquanto Murdoch lida com o sentido limite da realidade, com a própria estrutura ontológica. Só Murdoch pode esclarecer esse sentido porque é um híbrido, um mutante, um ser que, como Neo de The Matrix, tem o poder de atravessar realidades. Murdoch resiste à programação e desenvolve o poder dos aliens, sem a limitação de ter de ser alimentado por uma vontade coletiva, o que ecoa a questão das oposições individual/coletivo e liberdade/determinismo, afirmando-se o primeiro termo em ambos os casos, uma vez que Murdoch liberta os habitantes de Dark City do poder alienígena e permite-lhes ter uma existência unidimensional que lhes garante a continuidade e liberdade necessárias para a construção de uma identidade individual.

The Matrix assenta também na noção da realidade enquanto ilusão e na possibilidade de autodeterminação individual sobre poderes superiores e ordem dominante. No filme, os humanos vivem numa falsa realidade que se parece com o presente do mundo real, mas que é apenas sonhada, uma vez que as pessoas estão ligadas a um programa de realidade virtual que as sustenta enquanto fonte de energia para as máquinas que controlam 
o planeta. Para Peter Fitting ${ }^{30}$, a chave de leitura do filme está na luta coletiva para libertar os humanos da opressão, o que, independentemente do contexto distópico em que decorre, é um feito utópico.

Dark City e The Matrix podem classificar-se como distopias críticas, na medida em que o final encerra com a esperança de um lugar melhor, em resultado da ação de sujeitos que afirmam a sua autonomia contra a ordem dominante. Em ambos os filmes, as personagens habitam realidades construídas sem que tenham inicialmente consciência da sua artificialidade. São pseudorrealidades que, para Peter Fitting $(i d$.$) , representam as múltiplas$ formas em que governos e media se conjugam para obscurecer qualquer discussão significativa sobre os processos económicos e políticos da sociedade contemporânea.

Uma interpretação diferente é proposta por Fredric Jameson. Para ele, a ficção científica é importante, não pelo seu poder utópico mas pelo modo como trabalha os problemas ideologicamente fundamentais da modernidade tardia. Jameson concentra-se no conceito de totalidade negativa, que se vem a assumir como o oposto dialético da utopia. Totalidade negativa é, na época contemporânea, o sistema de relações do capitalismo. No seu ensaio mais influente sobre ficção científica, Progresso vs Utopia (1982), Jameson argumenta que as ficções científicas constituem deslocações para o futuro das contradições ideológicas do presente, mostrando, muitas vezes, que somos incapazes de imaginar transformações utópicas.

As narrativas de dissonância cognitiva, ao questionarem a natureza da realidade, questionam também o estatuto das experiências sensoriais e das memórias, uma vez que o tempo e o espaço das experiências se constituem como estruturas gnosiológicas e, consequentemente, como pilares identitários. A desorientação em relação ao estatuto ontológico da realidade traduz-se numa perda de garantia no conteúdo do eu, numa ausência de unificação e coerência das experiências individuais.

No filme Strange Days (Kathryn Bigelow, 1995), Lenny Nero (Ralph Fiennes) é um ex-polícia que vende playbacks, gravações das experiências

30 Unmasking the Real? Critique and Utopia in recent Science Fiction Films, in Moylan e Baccolini, 2003:155-165. 
de outras pessoas, daquilo que viram ou sentiram. Essas experiências, normalmente de sexo e violência, são utilizadas como droga, permitindo vivenciar uma realidade alternativa. Lenny é viciado nas gravações das suas próprias experiências românticas e sexuais com Faith (Juliette Lewis), a sua ex-namorada. Acaba por ser envolvido numa trama quando um assassino começa a pôr no mercado playbacks de assassinatos brutais, sugerindo que Faith será a próxima vítima. Com a ajuda de Mace (Angela Bassett), Lenny procura o assassino, e descobre ser um ex-polícia que tem um caso com Faith. No final do filme, Lenny mata o assassino, renuncia a Faith e à virtualidade dos playbacks e dá um beijo apaixonado a Mace durante os festejos da passagem para o novo milénio, o que permite ao espetador encarar otimisticamente o futuro e a capacidade individual (e coletiva) de renunciar à virtualidade e ilusão a favor da realidade concreta.

A questão da perceção relaciona-se também com a possibilidade de registo mental de experiências espacio-temporalmente situadas. A possível artificialidade das memórias cria uma dúvida existencial e identitária, como a vivida por Rachel, a androide a quem foram implantadas memórias e que se apaixona pelo humano Deckard no filme Blade Runner, ou por Quaid, o agente de Total Recall que compra um implante de memórias de uma férias em Marte e acaba por descobrir que toda a sua vida é construída sobre memórias implantadas e que a sua identidade é igualmente artificial. A indefinição entre a fantasia e a realidade está presente até ao fim do filme, quando Quaid se interroga se o que vive não será um sonho. O próprio indivíduo torna-se simulacro de si próprio, sem se distinguir claramente qual o original e qual a cópia. Como diz Hausser na gravação que deixa a Quaid (que, na realidade, é Hausser com memórias implantadas), "Prepara-te para a grande surpresa... Tu não és tu. Tu és eu!”

A questão da memória é recorrente na ficção científica das últimas três décadas, tornando-se central para a abordagem da possibilidade de duplicação do ser humano, quer por via tecnológica, quer por via biológica. As memórias, enquanto registo da vivência no tempo e no espaço e enquanto mecanismo de autenticação do passado, tornam-se chave de acesso e centro de identidade do eu. A sua transformação, por implante ou por apagamento, constitui uma forma de manipulação da essência do indivíduo, 
que, como acontece em Blade Runner e Total Recall (filmes em que também é sublinhada a constância da imagem na vida quotidiana) se vê obrigado a construir uma continuidade identitária com base em imagens protésicas de um passado que não the pertence.

As narrativas de espaço e tempo, opondo as categorias real/ideal ou real/ virtual, mostram, ao longo do cinema de ficção científica das décadas mais recentes, uma crescente incapacidade de pensar uma realidade com uma estrutura social, política, económica ou tecnocientífica superior à do mundo real, tendendo para visões distópicas e discrónicas que traduzem o desencanto em relação à racionalidade científico-tecnológica e às instituições de poder e o pessimismo em relação ao futuro. Essa tendência é acompanhada por um aumento da permeabilidade entre a realidade e a virtualidade, quer por construção tecnológica quer por manipulação percetiva, reveladora de ceticismo em relação à estrutura da própria realidade e à capacidade humana de distinguir a essência da aparência.

No entanto, as propostas da ficção científica de tempos e espaços outros apresentam-se como distopias críticas, visões que permitem refletir sobre as causas que conduziram à situação distópica e perspetivar estratégias de resolução ou, talvez mais importante, indicações sobre os comportamentos e atitudes a evitar para que um mau futuro não se transforme em presente concreto. 
(Página deixada propositadamente em branco) 


\section{CONCLUSÃO}

I told you so, you damned fools. Epitáfio desejado por H.G. Wells

O desafio que este livro propõe ao leitor é o de olhar para os filmes de ficção científica a que assistiu, não apenas como produtos de entretenimento, concebidos para despertar emoção e surpresa, mas enquanto ferramentas poderosas que moldaram a sua visão do mundo e alimentaram as suas reflexões sobre as condições de existência humanas.

A tese proposta é a de que a ficção científica é uma forma discursiva que permite pensar a alteridade e o futuro, extensões imaginadas da identidade e do presente, num mundo dominado por uma cultura científica e tecnológica. O seu crescimento enquanto narrativa acompanhou a crise da racionalidade moderna, cujos instrumentos, processos e modelos de conhecimento se mostraram insuficientes para imaginar e construir o futuro perfeito implicitamente prometido nos discursos de evolução e progresso.

A partir da década de 1970, a academização da ficção científica fornece-lhe um corpo teórico em que se pode confirmar esta tese, existindo um relativo consenso sobre a sua utilidade para explorar questões científicas, tecnológicas, sociais, políticas, culturais e identitárias, por permitir identificar as contradições do mundo concreto e imaginar como se poderão resolver ou acentuar com a passagem do tempo, mudança de espaço, transformações científicas e tecnológicas ou com a introdução da alteridade.

Uma das características que a distingue de outros géneros narrativos é o facto de escapar a qualquer tentativa de definição rigorosa movendo-se, numa 
espécie de jogo, em diversas categorias do mapeamento mental existente: afirma a realidade negando-a, inscreve-se num paradigma transcendendo-o, funda-se numa episteme criticando-a. As suas únicas fronteiras, que permitem distingui-la da fantasia ou de narrativas espacio-temporalmente deslocadas mas reflexivamente estéreis, são a obediência às leis naturais e aos princípios epistemológicos e lógicos, dos quais, extrapolativamente, se podem derivar a ciência e tecnologia do futuro ou de outros pontos da galáxia.

É a dimensão científica que está presente na sua génese, na sua história e até no currículo dos seus autores, que obriga a que o género assente num prolongamento da ciência e tecnologia reais. Deve apresentar uma mudança (novum) sem rutura, uma descontinuidade assente num prolongamento das técnicas e teorias existentes e aceites no momento da sua produção. A sua credibilidade e a capacidade para inquietar o espetador está fundada nessa continuidade, na capacidade de antecipar futuros verosímeis a partir das premissas que o presente fornece.

No entanto, a plausibilidade parece ser o seu único limite, daí que se vá construindo hibridamente, permitindo cruzamentos e confluências entre realidade e fantasia, espírito e matéria, passado e futuro, provável e improvável, imaginação e realidade, medo e esperança, temor e fascínio, fé e racionalidade, simbólico e concreto, utopia e distopia, eu e outro, familiar e estranho, ciências físicas e humanas, profecia e nostalgia, cognição e sublimação, esperança e medo. Apresenta mundos povoados por alienígenas, monstros, engenhos, humanos, máquinas, máquinas humanizadas, humanos mecanizados, cientistas, aventureiros, heróis, super-heróis, anti-heróis, criadores e criaturas. Retrata o futuro que pode ser e o passado e presente que poderiam ter sido como estratégias de interpelação do presente que é. Os seus horizontes são o infinito e a eternidade, e, no limite de qualquer um deles, pode encontrar-se o radicalmente diferente, que é intrinsecamente igual. Daí que qualquer leitura da ficção científica implique como competência descodificadora a imaginação crítica, a capacidade de perceber que ela não é mais do que uma reinvenção do humano, e que é nele que podemos encontrar a razão da sua existência.

A partir de uma panorâmica sobre a sua história, pode verificar-se que a ficção científica foi um género mutante, adaptando-se aos públicos e ao 
medium em que foi sendo difundida. Surge na Europa ligada à tradição do romance científico, mas só ganha identidade quando Hugo Gernsback começa a publicá-la nos Estados Unidos da América em magazines, em narrativas de otimismo tecnológico em relação ao sonho americano. Revistas pulp como Amazing Stories, Astounding Stories, The Magazine of Fantasy and Science Fiction e Galaxy Science Fiction são essenciais para a formação de escritores e públicos e para o desenvolvimento dos temas e iconografia do género.

A decadência dos magazines dá lugar a novos formatos de publicação, a edição de capa mole e de bolso, consumidos por uma nova geração intelectualmente mais exigente e ativamente envolvida na luta pelos direitos civis. A ficção científica reinventa-se, adequando-se ao modelo narrativo imposto pelo livro e às exigências dos novos públicos, fornecendo novamente as ferramentas para reinventar o futuro, adaptadas às necessidades do presente, muitas vezes recuperando elementos do passado. Pelo final da década de 1960, começa a esboçar-se uma ficção científica comprometida com a defesa de certas minorias, trazendo reflexões sobre género e a raça para o seu interior.

A massificação da ficção científica dá-se com a sua passagem para o audiovisual. A série Star Trek inaugura uma nova fase, mais fácil de consumir porque não obriga o recetor à tarefa de construir imaginativamente os mundos narrados. O novo medium vai contribuir para a formação de uma nova audiência que garante o sucesso do filme Star Wars e faz com que a ficção científica passe a ser um dos géneros cinematograficamente dominantes em Hollywood.

Nas últimas décadas, o cinema de ficção científica beneficia de uma plataforma mediática alargada graças à crescente permeabilidade entre televisão, vídeo, cinema, internet, jogos de computador e consolas. Prestando-se a múltiplas apropriações, quer pela diversidade e estranheza dos contextos e personagens, quer pelos temas propostos, quer por frequentemente envolver confronto e ação, a ficção científica ganha uma popularidade inequívoca.

Enquanto género popular, de difusão massiva, a ficção científica estrutura-se tematicamente em torno de quatro categorias: alteridade, tecnologia, tempo e espaço, que alternam a importância e centralidade de acordo com 
os contextos históricos de produção. Em cada década pode destacar-se uma das categorias, fruto das ansiedades dominantes. As lutas pela igualdade de género e pelos direitos civis fazem com que a alteridade seja a categoria dominante na década de 1970, promovendo uma visão otimista do outro, uma alteridade benévola capaz de entender e comunicar com os seres humanos sem intenção direta de os prejudicar. Na década de 1980 destaca-se a questão do desenvolvimento tecnológico, isoladamente ou enquanto instrumento ao serviço de interesses políticos, económicos ou militares, centrando-se na categoria tecnologia. Nos primeiros anos a ficção científica é, genericamente, tecnofóbica, como se verifica em filmes como Alien, The Terminator, Wargames e Robocop, refletindo os medos relativos à massificação do computador enquanto ferramenta de trabalho e de uso pessoal e crescente informatização do mundo. Mas o ciclo altera-se a meio da década e os filmes que assumiram um tom tecnofóbico lançam sequelas onde se manifesta a capacidade humana de utilização pacífica da tecnologia. É o caso de 2010 - The Year we Made Contact, Aliens, Terminator 2 e Robocop 2 , voltando o tom tecnofóbico a ser dominante apenas a partir dos últimos anos do milénio.

A questão da tecnologia conduz também à questão das fronteiras entre o humano e o inumano, e às múltiplas formas de permeabilização e hibridação entre natural/artificial, original/cópia, razão/emoção ou homem/ mulher. A diluição das antinomias traduz, simultaneamente, a crescente dependência da máquina, a crescente aliança entre a tecnologia e o corpo, a crise identitária do sujeito pós-moderno e a exaustão das antinomias enquanto ferramentas para pensar a realidade.

Tempo e espaço tornam-se categorias dominantes a partir da década de 1990, conjugadas com a alteridade e a tecnologia. A informatização e virtualização da realidade e o domínio da imagem, do simulacro no sentido dado por Baudrillard, dificultam a capacidade de conhecer e ajuizar, de distinguir o real do aparente e o acessório do essencial. Uma vaga de filmes reflete esta indeterminação em relação ao que ancora a nossa perceção à realidade. Narrativas como The Lawnmower Man, Virtuosity, Strange Days, Dark City e The Matrix centram-se nas possibilidades de mediação da perceção através de jogos, dispositivos ou entidades estranhas ao humano, 
originando narrativas de dissonância cognitiva que afirmam que o que percebemos não corresponde à realidade, conduzindo a um questionamento simultaneamente epistemológico e ontológico. Traduzem também a incerteza existencial e fornecem uma sensação de pós-futuro, de exaustão do sonho tecnológico expansionista da década de 1950, dos ideais sociais e políticos das décadas de 1960 e 1970 e da euforia de fim de milénio.

A análise de cada uma das categorias estruturantes da ficção científica: alteridade, tecnologia, tempo e espaço, permite estabelecer subgéneros e determinar os modos de abordagem propostos ao longo das décadas, nomeadamente na identificação e resolução das dicotomias centrais do pensamento moderno, que Donna Haraway (1991) resume a três: humano e não humano, orgânico e não orgânico, físico e não físico. Adaptando-as às categorias em análise, poderemos considerar que a alteridade trata da relação entre humano e não humano, a tecnologia da oposição entre orgânico e maquínico, e que espaço e tempo, tomados conjuntamente, obrigam ao questionamento do físico e do não físico, o que remete para as noções de real e ideal, ou real e virtual.

Tomando-se o conceito de alteridade como nuclear, concluiu-se que esta pode aparecer como o radicalmente diferente ou como uma variação mais ténue da mesmidade, obrigando, em qualquer dos casos, a refletir sobre os limites e potencialidades do humano. Os conceitos em conflito são o eu e o outro, categorias que possibilitam a diferenciação individual e coletiva, e que na ficção científica se traduzem na oposição humano/não humano. O grau de diferenciação pode ser biológico, físico, psicológico, social ou cultural e pode ser interpretado de modo literal ou metafórico, uma vez que as narrativas de ficção científica permitem uma leitura conotativa que articula discursos normalmente marginalizados e facilita a reflexão crítica acerca da diferença. O outro, por oposição ao eu dominante, pode ser o não orgânico, o não humano, o não caucasiano, o não heterossexual, o não homem, que se traduz numa vasta galeria de alienígenas, antropomórficos ou xenomórficos, individuais ou coletivos, livres ou determinados, benévolos ou malévolos, mais próximos ou mais distantes da compreensão humana.

Não se pode conceber o absolutamente estranho, por isso pensar a alteridade é sempre pensar graus de diferença, nunca a diferença absoluta. 
O desafio da ficção científica é mostrar graus superiores de diferenciação sem perder as referências que permitem a atribuição de significado. Assim, é no eu que se encontram as grelhas de referência para compreender o outro, embora a identidade seja, ela própria, um efeito da diferença.

É no binómio eu/outro, humano/não humano, que encontramos a humanidade imaginada, a narrativa do que constitui a essência do ser humano e que a ficção científica oferece na forma de encontro com entidades alienígenas, articulando diversos graus de otimismo ou pessimismo em relação ao humano e ao inumano.

O cinema de ficção científica propõe vários tipos de alteridade. Num primeiro plano encontra-se a alteridade alienígena, de origem não humana nem mecânica, proveniente do espaço celeste. Nestes casos o alien representa o radicalmente diferente, espacio-temporalmente distante, distinguindo-se do alien que se pode encontrar no seio da própria humanidade. Neste tipo enquadram-se narrativas de hibridação, possessão ou contágio do outro em relação ao eu ou, mais raramente, do eu em relação ao outro. Mas a alteridade pode ser encontrada também nas metáforas, naquilo que o não humano pode representar em termos de diferenciação rácica, étnica, de género ou de orientação sexual no seio do mundo real. Um terceiro tipo de alteridade, frequentemente proposta na ficção científica recente, é de base tecnológica, típica das narrativas em que a máquina se instituiu como lugar do não humano, traduzindo os modos de encarar o avanço da tecnologia e a sua relação com o humano.

Da análise de alguns dos filmes mais paradigmáticos da ficção científica das últimas décadas, centrados na alteridade alienígena, concluiu-se que esta é predominantemente retratada como malévola, principalmente ao longo da década de 1950 e a partir de finais da década de 1970, traduzindo-se em narrativas de guerra, invasão ou alienação, em que a ameaça de destruição é coletiva e que mobilizam a humanidade em torno do objetivo comum de lutar pela sobrevivência ou libertação. No entanto, além de tornar presente a ideia do inumano como perigoso, mais avançado em termos tecnológicos e militares e orientado pelo desejo de conquista e domínio, muitos destes filmes enquadram-se dentro das críticas apontadas por Susan Sontag (in Redmond, 2004) por apostarem na espetacularização do desastre 
e na devastação dos espaços simbólicos da cultura ocidental, podendo o alien representar qualquer dos inimigos sociopolíticos do momento.

As narrativas em que o outro é uma variação ou mutação do eu são as que permitem uma leitura mais clara do efeito da alteridade no humano, através de processos de infeção, desvio ou mutação que ameaçam ou destroem a integridade biológica, psicológica ou emocional, originando processos de sobre-humanização ou sub-humanização, de pós-humanidade que se concretiza em múltiplas formas de hibridação. Estes filmes refletem as ansiedades relativas às transgressões que a alteridade, a ciência ou a tecnologia podem operar no corpo humano, seja por invasão, contágio, guerra biológica, engenharia genética ou efeito da destruição da bioesfera, de que são exemplo os filmes Outbreak, Species, The 6th Day e The Island. Este tipo de narrativas aborda as questões da identidade e da moral perante os desafios científicos, nomeadamente da clonagem, instituída ao longo das últimas duas décadas como um espaço privilegiado de discussão uma vez que o clone, apesar de morfologicamente igual, se constitui como ontologicamente diferente.

Enquanto alegoria das tensões e conflitos sociais existentes, a ficção científica permite pensar os outros que existem no interior da comunidade humana. O seu modo futuro permite imaginar cenários de igualdade, antecipando alterações nas representações de género. Ellen Ripley e Sarah Connor desafiam os estereótipos femininos e introduzem no cinema as action babes, heroínas de ação que se tornam frequentes nos vários géneros cinematográficos a partir da década de 1990, refletindo as alterações na atribuição de papéis que ocorrem na própria realidade.

Também a representação da diferença rácica reflete as tendências culturais dominantes. Uhura, em Star Trek, traduz os ideais igualitários das décadas de 1960 e 1970, a que se segue uma demonização do negro ao longo da década de 1980, e, a partir da década de 1990 o afro-americano passa a ser o próprio herói ou um auxiliar essencial na recuperação dos valores centrais da humanidade. Mulher e negro, tomados metafórica ou literalmente, deixam de ser lugar de diferença e passam a ser parte integrante do eu ocidental, refletindo a tendência multicultural de aceitação e assimilação do outro.

A análise da alteridade nas suas múltiplas configurações permite concluir que a resolução proposta pela ficção científica para o conflito identidade $v$ s. 
alteridade, traduzido na dicotomia humano/não humano alienígena, não é de conciliação. O alien, distante do homem, é uma categoria estática, mantendo por isso uma oposição inultrapassável. Normalmente malévolo, não oferece possibilidade de conciliação, seja por coexistência ou hibridação. Quando se funde com o humano, fá-lo numa lógica de domínio, de colonização ou possessão, permitindo a congregação da humanidade em torno de um objetivo comum: a sobrevivência e manutenção do seu modo de vida e valores.

Clones, mutantes e super-heróis, ainda que diferentes, são variações do humano em que o espetador pode demarcar a identidade e a diferença, que servem essencialmente para alertar para os perigos do mau uso dos recursos, da tecnologia ou da ciência, para os desvios em relação à normalidade e para a luta individual. Estes híbridos acabam curados, destruídos, foragidos, ocultos no anonimato ou integrados na sociedade, restabelecendo o status quo por anulação ou encobrimento da diferença.

A tecnologia permite também pensar a alteridade, instituindo-se como lugar do não humano, como elemento opositor ou como espaço de conciliação, de encontro do humano com uma outra dimensão da sua própria natureza. Em qualquer dos casos, permite a reflexão em torno da segunda antinomia proposta por Haraway, humano/máquina, e, colateralmente, a relação entre razão e emoção, natural e artificial, criação e criatura, liberdade e determinismo. Mas a tecnologia pode também ser representada como dispositivo que permite a mediação entre o ser humano e o que lhe é estranho, e entre o mundo zero e outras formas de realidade, permitindo ou justificando o posicionamento físico e temporal da própria narrativa. Em qualquer dos casos, pode ser tomada positiva ou negativamente, assumindo um tom tecnofóbico ou tecnofílico que traduz as visões pessoais dos autores, mas também as ansiedades e o modo de encarar a racionalidade tecnocientífica do momento em que são produzidas as narrativas.

Computadores, robôs, androides e ciborgues são figuras de fusão entre humano e maquínico que permitem pensar a tecnologia como outro, mas também como extensão do eu. O computador incorpora a inteligência humana, livre das ambiguidades e ambivalência introduzidas pelas sensações e sentimentos, gerando por isso o medo de que esta racionalidade superior possa suplantar a dos seus criadores e obrigando a deslocar para a emoção 
a especificidade da essência humana. Narrativas de computadores totalitários podem encontrar-se na ficção científica cinematográfica da primeira metade da década de 1980, traduzindo a inquietação com a crescente informatização do mundo, e voltam a dominar no final do milénio, desta vez associadas à capacidade de gerar ambientes e entidades artificiais que interferem com a existência humana.

Se os computadores representam a capacidade de pensar, os robôs representam a capacidade de executar tarefas físicas de modo mais eficiente e fiável do que os seres humanos. Frequentemente retratados como auxiliares fiéis, os robôs do cinema de ficção científica só se tornam malévolos quando colocados ao serviço de forças do mal, sejam alienígenas, humanas ou tecnológicas.

A partir da década de 1980 as narrativas em que a tecnologia constitui o novum passam a recorrer sobretudo às figuras do androide e do ciborgue, seres que representam a fusão da tecnologia com a humanidade, revelando a permeabilidade e a fluidez das duas categorias. Os androides, que são máquinas desenhadas para parecerem humanos, e os ciborgues, que são humanos compostos por próteses tecnológicas, apagam as distinções físicas e comportamentais entre homem e máquina, obrigando a refletir sobre a identidade e sobre as fronteiras entre os conceitos de humano e não humano, criador e criatura, traduzindo também a ansiedade pós-moderna com a distinção entre original e cópia, realidade e simulacro.

Donna Haraway considera que o ciborgue é a figura da ficção científica que permite pensar a fluidez do presente e a imaginação do futuro, invertendo e deslocando os dualismos, hierarquias e identidades instituídas. Ciborgues e androides, híbridos de máquinas e organismos, são criaturas que pertencem simultaneamente à realidade social e à ficção, e por isso podem considerar-se definidoras da ontologia pós-moderna: constituem identidades fraturadas, em que se dissolvem múltiplas antinomias, como corpo e alma, macho e fêmea, realidade e aparência, agente e recurso, construtor e constructo.

Quer o ciborgue quer o androide podem ser retratados positiva ou negativamente, sendo figuras dominantes na década de 1980, encarnadas por personagens como Ash, de Alien, Roy Batty, de Blade Runner, Bishop, de 
Aliens, os modelos T800 e T1000 de Terminator, ou Murphy, de Robocop. Estabelecida a semelhança física e comportamental, uma das questões centrais destes filmes é a determinação daquilo que distingue a máquina do homem, considerando-se, nos filmes de matriz tecnofóbica, que é a capacidade de sentir empaticamente o que distingue os humanos e os torna superiores, enquanto as narrativas de tom mais tecnofílico são antropologicamente mais pessimistas e sublinham a superioridade das máquinas em relação ao humano pela capacidade que revelam de se sacrificarem para benefício da humanidade ou dos seus valores, o que poderá traduzir o desencanto com as condições modernas de existência individual e coletiva e a necessidade ou desejo de reinventar a humanidade, recapturando a dimensão espiritual ou afetiva que permite o altruísmo que só as máquinas parecem ser capazes de manifestar.

Nas narrativas de tecnologia centradas no ciborgue e no androide enquanto instâncias de cruzamento, a resolução da antinomia é feita através da capacidade de sentir de forma positiva, empática. Quando os sentimentos negativos são atribuídos à máquina, como a inveja que HAL de 2001 sente pelos astronautas, a repulsa que o agente Smith expressa pela humanidade em The Matrix ou a admiração que Ash manifesta pelo alien, associam-se mais à frieza racional do que à emocionalidade humana.

No final dos anos de 1990, o cinema de ficção científica centra-se mais na capacidade tecnológica de mediar a experiência do mundo, expressa em filmes como Strange Days, eXistenZ ou The Matrix, deslocando a dicotomia humano/máquina das reflexões antropológicas e existenciais ligadas à tecnologia para questões de ordem ontológica.

O questionamento do estatuto ontológico da realidade e do grau de verosimilhança das nossas perceções conduz à terceira dicotomia proposta por Haraway, entre o físico e o não físico, e ao tempo e espaço enquanto categorias de análise.

As narrativas de espaço e tempo, opondo as categorias real/ideal ou real/virtual, conduzem, antes de mais, à conclusão de que o cinema de ficção científica, principalmente a partir de meados da década de 1990, denota a crescente incapacidade de pensar utopicamente, propondo visões em que a realidade social, política, tecnológica ou científica é pior do que 
a do mundo zero, numa projeção distópica e discrónica do real. No entanto, as propostas da ficção científica de tempos e espaços outros, piores do que o presente, podem classificar-se como distopias críticas, visões que permitem refletir sobre as causas que conduziram à situação distópica e perspetivar estratégias de resolução ou de prevenção que podem ser elaboradas e adotadas no presente concreto.

A tendência para a narrativa distópica ou discrónica é acompanhada por um aumento da permeabilidade entre a realidade e a virtualidade, seja por ação direta da tecnologia ou por manipulação sensorial, percetiva ou cognitiva, reveladora de algum ceticismo gnosiológico. Dark City e The Matrix são exemplos de narrativas de dissonância cognitiva, que afirmam a realidade enquanto ilusão, enquanto construção artificial levada a cabo por entidades não humanas. No entanto podem classificar-se como distopias críticas na medida em que encerram com a esperança de um lugar melhor, resultante da ação de sujeitos que afirmam a sua autonomia contra a ordem dominante, heróis mutantes, que integram em si o poder não humano dos alien ou das máquinas e aprendem a reconstruir, eles próprios, a realidade, propondo-se, mais uma vez, a hibridação como chave para a resolução dos conflitos antinómicos humano/não humano e real/virtual.

Mais complexa é a questão da validade das perceções ou memórias. A memória torna-se central para a abordagem da possibilidade de duplicação de seres humanos, quer por via tecnológica, quer biológica. Enquanto registo da vivência no tempo e no espaço e enquanto mecanismo de autenticação do passado, as memórias tornam-se pilares identitários. Através de implante ou apagamento, a transformação da memória constitui uma forma de manipulação da essência do indivíduo, que abala a sua continuidade existencial, construindo uma identidade com base em imagens protésicas de um passado que não the pertence.

A proposta de Baudrillard de que o simulacro pode assumir um estatuto ontológico igual ou superior ao do original é recorrente na ficção científica das últimas décadas, colocando-se em todas as categorias de análise. A cópia do humano, seja feita por clonagem ou replicação tecnológica, tenha ou não memórias implantadas, adquire legitimidade existencial, sobretudo nos filmes posteriores à segunda metade da década de 1980. Já quando a questão da 
simulação se aplica à realidade ou às perceções espacio-temporalmente situadas, a ficção científica mantém irreconciliáveis o real e o virtual, o original e a cópia, a matéria e a imagem, refletindo o pessimismo teórico relativo à realidade e existência pós-modernas e a necessidade de ancoragem gnoseológica à realidade concreta e não ao seu reflexo ou simulacro.

Pela diversidade de temas e formas de abordagem, parece legítimo concluir-se que a ficção científica, usando a imaginação crítica como ferramenta e tendo a coerência lógica e epistemológica como exigência, permitiu moldar mentalidades e propor visões de mundo, fornecer esquemas mentais e apresentar soluções imaginadas para as grandes dicotomias do pensamento ocidental, traduzindo as ansiedades existenciais, epistemológicas, ontológicas e antropológicas provocadas pelo pensamento pós-moderno.

Mas o seu maior poder advém do medium em que é expressa. Enquanto forma de entretenimento de massas e enquanto género de sucesso, a ficção científica cinematográfica tem o poder de chegar a públicos que, de outro modo, dificilmente seriam mobilizados para uma análise crítica do presente e para uma reinvenção de futuro, em que são articuladas questões relativas aos limites e fronteiras de classe, género, identidade, alteridade, tecnologia, ciência, racionalidade, afetividade, maternidade, paternidade, criação, normalidade, aparência e essência. Para a mesma questão, que expressa as ansiedades do momento, os filmes de ficção científica propõem múltiplas abordagens e soluções, sendo por vezes simultaneamente otimistas e pessimistas, distópicos e utópicos, celebratórios e críticos.

É esta ambivalência, usada como estratégia de adequação a uma audiência global ou reflexo da incapacidade pós-moderna de enunciar certezas, que torna os filmes de ficção científica reflexivamente férteis, fomentando no espetador o pensamento crítico e assumindo que é ele quem, no mundo zero de todos os futuros, tem a tarefa real de construir o universo imaginado a que quer pertencer. 


\section{B I B LI O GRAFIA}

ANDREW, Dudley (1984). Concepts in Film Theory, New York: Oxford University Press.

ANG, Ien (1996). Living Room Wars: Rethinking Media Audiences for a Postmoderm World; London: Routledge.

ARONOWITZ, Stanley, ed.(1996).Technoscience and Cyberculture. New York: Routledge.

BACCOLINI, Raffaella e MOYLAN, Tom (2003). Dark Horizons: Science Fiction and the Dystopian Imagination. New York and London: Routledge.

BARR, Marleen (1992). Feminist Fabulation: Space/Postmodern Fiction. Iwoa: University of Iwoa Press.

BAUDRILLARD, J. (1991). Simulacros e Simulações. Lisboa: Relógio d'Água.

BAUDRILlaRD, J. (1997). Écran Total. Paris: Éditions Galilée.

BAZIN, André (1992); O que é o Cinema. Lisboa: Livros Horizonte.

BEL, Andrew e GARRET, Peter eds. (2001); Approaches to Media Discourse. Oxford: Blackwell Publishers.

BECKER, Howard S. (1982). Art Works. Berkeley, Los Angeles, London: University of Califórnia Press.

BIZONY, Piers (1994). 2001: Filming the Future. London: Aurum Press Limited.

BORDwELl, David e THOMPSON, kristin (1993). Film Art. New York: McGraw-Hill.

BROOKER, Will and Jermyn, Deborah eds. (2003); The Audience Studies Reader, London and NY: Routledge.

BROWNE, Nick ed. (1998). Refiguring American Film Genres: Theory and History. Berkley, Los Angeles, London: University of California Press.

BUKATMAN, Scott (1993). Terminal Identity: The Virtual Subject in Postmodern Science Fiction. Durham and London: Duke University Press.

BUKATMAN, Scott (1997). Blade Runner. London: British Film Institute.

BURAWOY, Michael et al. (1991). Ethnography Unbound. Power and Resistance in the Modern Metropolis. Berkeley: University of Califórnia Press.

BURKE, Kenneth (1989). On Symbols and Society. Chicago and London: The University of Chicago Press.

CARTMELL, Deborah et al., eds. (1999). Alien Identities: Exploring Differences in Film and Fiction. London: Pluto Press.

CASTELLS, Manuel (1996). The Information Age: Economy, Society and Culture. Oxford: Basil Blackwell. 
CHATMAN, Seymour (1990). Coming to Terms: The Rhetoric of Narrative in Fiction and Film. Ithaca: Cornell University Press.

CLARESON, Thomas D. (1990). Contemporary American Science Fiction: The Formative Period 1926-1970. Columbia: University of South Carolina Press.

CLUTE, John e NICHOLLS, Peter (1993). The Enciclopedia of Science Fiction. New York: Orbit. COOK, David (1996). A History of Narrative Film. New York: Norton.

COOK, Hardy e BERNINK, Mieke (1999). The Cinema Book. London: British Film Institute.

DOWNING, Jonh; MOHAMMADI, Ali; MOHAMMADI, Annabelle (1990). Questioning the Media: A critical introduction. Newbury Park: Sage Publications.

DEleuze, G. e GuATARI, Félix (2004). O Anti-Édipo: Capitalismo e Esquizofrenia. Lisboa: Assírio e Alvim.

DELEUZE, Gilles (1986). Cinema I: The Movement Image. London: Athlone Press.

DELEUZE, Gilles (1986). Diferença e Repetição. Rio de Janeiro: Graal.

ECO, Umberto (1986). Viagem na Irrealidade Quotidiana. Lisboa: Difel.

ELSAESSER, Thomas e BUCKLAND, Warren (2002). Studying Contemporary American Film: A Guide to Movie Analysis. New york: Oxford University Press.

COElHO, Eduardo Prado, ed. (s/d). Estruturalismo: Antologia de Textos Teóricos. Lisboa: Portugália Editora.

FEATHERSTONE, Mike (1995). Undoing Culture - Globalization, Postmodernism and Identity. London: Sage Publications.

FEATHERSTONE, Mike e BURROWS, Roger, eds. (1995). Cyberspace, Cyberbodies, Cyberpunk: Cultures of Technological Embodiment. London: Sage Publications.

FEEDMAN, Carl (2000). Critical Theory and Science Fiction. Hanover: Wesleyan University Press.

FOUCAUlT, M. (s/d). Vigiar e Punir. Petrópolis: Vozes.

FRANKLIN, H. Bruce (1966). Future Perfect: American Science Fiction of the Nineteenth Century. New York / London: Oxford University Press.

FREEDMAN, Carl (2000). Critical Theory and Science Fiction. Hanover and London: University Press of New England.

FRENCH, Sean (1996). The Terminator. London: British Film Institute.

GALlARDO, Ximena e SMITH, C. Jason (2004). Alien Woman: The Making of Lt. Ellen Ripley. New York, London: Continuum.

GEADA, Eduardo (1998). Os mundos do Cinema. Lisboa: Editorial Notícias.

GIBSON, William (1984). Neuromante. Lisboa: Gradiva.

GRANT, Barry Keith (2003). Film Genre Reader III. Austin: University of Texas Press.

GRILO, João Mário (1997). A Ordem no Cinema: Vozes e Palavras de Ordem no Estabelecimento do Cinema em Hollywood. Lisboa: Relógio de Água Editores.

HALL, Stuart e GAY, Paul du, eds. (1996). Questions of Cultural Identity. London: Sage Publications.

HALL, Stuart (1997). Identidades Culturais na Pós-Modernidade. Rio de Janeiro: DP\&A Editora.

HARAWAY, Donna (1989). Primate Visions: Gender, Race and Nature in the World of Modern Science. New York: Routledge.

HARAWAY, Donna (1991). Simians, Cyborgs, and Women. London: Free Association Press.

HARDY, Phil ed. (1995). The Aurum Film Encyclopedia: Science Fiction. London: Aurum Press. 
HEATH, Stephen (1981). Questions of Cinema: Theories of Representation and Difference. Bloomington: Indiana University Press.

HEIDEGGER, Martin (2001). Serenidade. Rio de Janeiro: Instituto Piaget.

HEIDEGGER, Martin (2002). Ensaios e Conferências. Petrópolis: Vozes.

HENDERSON, C. J. (2001).The Encyclopedia of Science Fiction Movies from 1987 to the Present. New York: Checkmark Books.

HUBBARD, L. Ron (1978). Dianética: A Ciência Moderna da Saúde Mental. Mem Martins: Publicações Europa- América.

JAMES, Edward e MENDLESOHN, Farah, eds. (2003). The Cambridge Companion to Science Fiction. Cambridge: Cambridge University Press.

JAMES, Edward (1994). Science Fiction in the Twentieth Century. Oxford/New York: Oxford University Press.

JAMESON, Fredric (1995). The Geopolitical Aesthetic: Cinema and Space in the World System. Bloomington, Indiana: Indiana University Press.

JAMESON, Fredric (2005). Archaeologies of the Future: The Desire Called Utopia and Other Science Fictions. New York: Verso.

KANT, Emmanuel (1989). Crítica da Razão Pura. Lisboa: Fundação Calouste Gulbenkian.

KAVENEY, Roz (2005). From Alien to the Matrix: Reading Science Fiction Film. London, New York: I. B. Tauris.

KUHN, Annette, ed. (1990). Alien Zone: Cultural Theory and Contemporary Science Fiction Cinema. London, New York: Verso.

KUHN, Annette ed. (1999). Alien Zone II: The Spaces of Science Fiction. London, New York: Verso.

LACEY, Nick (1998). Image and Representation - Key Concepts in Media Studies. Hampshire, New york: Palgrave.

LAPSLEY, Robert e WESTLAKE, Michael (1996). Film Theory: An Introduction. New York: Manchester University Press.

LAVERY, David (1992). Late for the Sky: The Mentality of the Space Age. Carbondale, Edwardsville: Southern Illinois University Press.

LENAFU, Sarah (1989). Feminism and Science Fiction, Bloomington, Indianopolis: Indiana University Press.

MALMGREN, Carl D. (1991). Wolds Apart - Narratology of Science Fiction. Bloomington e Indianapolis: Indiana University Press.

MALTBY, Richard (1995). Hollywood Cinema: An Introduction, Oxford: Blackwell Publishers.

MAST, Gerard; COHEN, M. e BRAUDY, Leo, eds. (1992). Film Theory and Criticism: Introductory Readings, New York: Oxford University Press.

MCCAFERY, Larry ed. (1994). Storming the Reality Studio: A Casebook of Cyberpunk and Postmodern Science Fiction. Durham: Duke University Press.

MCCRACKEN, Scott (1998). PULP: Reading Popular Fiction. Manchester e New York: Manchester University Press.

MCFARLANE, Brian (1996). Novel to Film: An Introduction to the Theory of Adaptation, Oxford: Claredon PressMETZ, Christian (1974). Film Language: A Semiotics of the Cinema. New York: Oxford University Press.

METZ, Christian (1982). Psychoanalysis and Cinema: The Imaginary Signifier. London: Macmillan. 
MILLER, Gabriel, (1981). Screening the Novel - Rediscovered American Fiction in Film. New York, Oxford: Oxford University Press.

MITRY, Jean (1990). The Aesthetics of the Cinema. Bloomington: Indiana University Press.

MONACO, James (1981). How to Read a Film - The Art, Tecnhology, Language, History and Theory on Film and Media. New york, Oxford: Oxford University Press.

MOSCARIELlO, Angelo (1995). Como ver um filme. Lisboa: Editorial Presença.

NEUMAN, Dietrich (1999). Film Arquitecture - From Metropolis to Blade Runner. Munique, London: Prestel.

NEVES, Josélia (1999). A Adpatação de Henry James ao Cinema: o Caso de The Portrait of a Lady - Dissertação de Mestrado em Estudos Ingleses. Departamento de Línguas e Culturas: Universidade de Aveiro.

PARRINDER, Patrick, ed. (2000). Learning from other Worlds: Estrangement, Cognition and the Politics of Science Fiction and Utopia. Liverpool: Liverpool University Press.

PARRINDER, Patrick, ed. (1979). Science Fiction: A Critical Guide. London, New york: Longman.

PENLEY, Constance et al., eds. (1993). Close Encounters - Film, Feminism, and Science Fiction. Minneapolis, London: University of Minnesota Press.

PERKOWITZ, Sidney (2007). Hollywood Science - Movies, Science and the End of the World. New York: Columbia University Press.

REDMOND, Sean, ed. (2004). Liquid Metal: The Science Fiction Film Reader. London, New York: Wallflower Press.

ROBERTS, Adam (2000). Science Fiction. London, New York: Routledge.

ROBERTS, Robin (1993). A New Species: Gender and Science in Science Fiction. Urbana, Chicago: University of Illinois Press.

ROSE, Mark (1981). Alien Encounters: Anatomy of Science Fiction. Cambridge, Massachusetts: Harvard University Press.

ROSE, Mark, ed. (1976). Science Fiction: A Collection of Critical Essays. New York: Prentice-Hall.

SAMMON, Paul M. (1996). Future Noir: The Making of Blade Runner. New York: Harper Collins Publishers.

SAWYER, Andy e SEE, David, eds. (2000). Speaking Scinece Fiction: Dialogues and Interpretations. Liverpool: Liverpool University Press.

SCHELDE, Per (1993). Androids, Humanoids, and Other Science Fiction Monsters: Science and Soul in Science Fiction Movies. New York, London: New York University Press.

SCHOLES, Robert (1968). Elements of Fiction. New York: Oxford University Press.

SCHOLES, Robert (1975). Structural Fabulation: An Essay on Fiction of the Future; London: University of Notre Dame Press.

SCHOLES, Robert (1979). Fabulation and Metafiction.University of Illinois Press.

SEARLES, B. e LAST, M. (1979). A reader's guide to science fiction. New York: Facts on File.

SOBCHACK, Vivian Carol (1980). The Limits of Infinity: The American Science Fiction Film. New Jersey: Barnes and Co.

SUVIN, Darko (1979). Metamorphoses of Science Fiction: On the poetics and History of a Literary Genre. New Haven, London: Yale University Press.

TElOTTE, J. P. (1995). Replications - A Robotic History of the Science Fiction Film. Urbana / Chicago: University of Illinois Press.

TElOTTE, J. P. (2001). Science Fiction Film. Cambridge: Cambridge University Press. 
THOMSON, David (1998). The Alien Quartet. London: Bloomsbury Publishing.

TRUFFAUT, Francois (1954). A Certain Tendency of the French Cinema, from Cahiers du Cinema, retirado de: http//media.wiley.com/product_data/excerpt/34/.../1405153334.pdf (19/08/2009).

TURKLE, Sherry (1995). Life on the Screen. Cambridge: MIT Press.

WELDES, Jutta, ed. (2003). To Seek Out New Worlds: Exploring Links between Science Fiction and World Politics. New York: Palgrave Macmillan.

WELLS, H. G. (1994). A Modern Utopia. London: J. M. Dent

WOLFE, Gary K. (1986). Critical Terms for Science Fiction and Fantasy: A Glossary and Guide to Scholarship. Connecticut: Greenwood Press.

YefFETH, Glenn, ed. (2003). Taking the Red Pill - Science, Philosophy and Religion in The Matrix. Dallas: Benbella Books. 
(Página deixada propositadamente em branco) 


\section{FILMOGRAFIA}

2001 - A Space Odyssey. Stanley Kubrick, 1968.

2010 - The year we made contact. Peter Hyams, 1984.

A.I.- Artificial Inteligence. Steven Spielberg, 2001.

Aelita. Protazanov, 1924.

Alien (Alien - O Oitavo Passageiro). Ridley Scott, 1979.

Aliens (Alien - O Reencontro Final). James Cameron, 1986.

Alien³. David Fincher, 1992

Alien 4 (A Ressurreição). Jean-Pierre Jeunet, 1997.

Armageddon. Bay, 1998.

Batman. Tim Burton, 1989.

Batman Returns. Tim Burton, 1992.

Blade Runner (Blade Runner - Perigo Iminente). Ridley Scott, 1982.

Creation of the Humanoids. Wesley Barry, 1962.

Cutthroat Island. Renny Harlin, 1995.

Dante's Peak. Donaldson, 1997.

Dark City. Alex Proyas, 1998.

Deep Impact. Leder, 1998.

E.T.- The Extra-Terrestrial. Steven Spielberg, 1982.

Escape from LA. John Carpenter, 1996.

Escape from NY. John Carpenter, 1981.

eXistenZ. David Cronenberg, 1999.

Fly, The. David Cronenberg, 1986.

Forbiden Planet. Wilcox, 1956.

Gattaca. Andrew Niccol, 1997.

I Married a Monster from Outer Space. Gene Fowler Jr., 1958.

Independence Day. Roland Emmerich, 1996.

Invaders from Mars. William Menzies, 1953.

Invasion of the Body Snatchers. Don Siegel, 1956. 
Invasion of the Saucermen. Edward L. Cahn, 1957.

Invisible Invaders. Edward L. Cahn, 1959.

It Came from Beneath the Sea. Robert Gordon, 1954.

It Came from Outer Space. Jack Arnold, 1953.

Johnny Mnemonic (Johnny Mnemonic). Robert Longo, 1995.

Jurassic Park. Spielberg, 1993, 1997 e 2001.

Mars Attacks!. Burton, 1996.

Matrix, The (Matrix). Andy e larry Wachowski, 1999.

Metropolis (Metropolis). Fritz Lang, 1926.

Minority Report (Relatório Minoritário). Steven Spielberg, 2002.

Monkey Business. Hawks, 1952.

One Hundred Years After. Realizador desconhecido, 1911.

Phantom from Space. Lee Wilder, 1953.

Plan 9 from Outer Space. Wood Jr., 1956.

Resident Evil. Paul W. S. Anderson. 2002.

Robocop (Robocop). Paul Verhoeven, 1987.

Robocop 2 (Robocop 2). Irvin Kershner, 1990.

Star Trek - The Motion Picture. Robert Wise, 1982.

Terminator 2 (O Exterminador Implacável 2). James Cameron, 1991.

Terminator, The (O Exterminador Implacável). James Cameron, 1984.

The Airship. Madsen, 1917.

The Beast from 20000 Fathoms. Lourié, 1953.

The Beast with a Million Eyes. David Kramarsky, 1955.

The Blob. Irvin Yeaworth Jr, 1958.

The Brain Eaters. Bruno VeSota, 1958.

The Comet. Realizador desconhecido, 1910.

The Creature from the Black Lagoon. Jack Arnold, 1954.

The Day after Tomorrow. Emmerich, 2004.

The Island of Dr. Moreau. Frankenheimer, 1996.

The Last man on Earth. Blystone, 1924.

The New Adventures of King Kong. Willis O'Brien, 1952.

The Snow Creature. Lee Wilder, 1954.

Them!. Douglas, 1954.

Thing, The (A Coisa). John Carpenter, 1982.

Thirteenth Floor. Josef Rusnak, 1999.

This Island Earth. Newman, 1955.

Total Recall. Paul Verhoeven, 1990.

Volcano. Jackson, 1997.

War Games. John Badham, 1983. 
War of the Worlds. Byron Haskin, 1954.

War of the Worlds. Spielberg, 2005.

Wizard of Oz .Victor Fleming, 1939. 


\section{Série Investigação}

Imprensa da Universidade de Coimbra Coimbra University Press 2012 